\title{
فاعلية كتاب رقمي تفاعلي لتنمية الثقافة الجيولوجية لأطفال الروضة
}

إعداد

د/ نورهان محمد بهجت أنور (")

\section{مقدمة}

تسعى جميع دول العالم، المتقدمة والنامية إلى تطوير مناهج التعليم فيها بصورة مستمرة، حيث تأتي مناهج العلوم في مقدمة اهتمامات المعنيين بوضع سياسات التعليم والتخطيط لتطويرها، وتحسين مستوى مخرجاتها، والعصر الحالي يحتاج إلي أفراد لديهم ثقافة علمية واسعة تساعدهم علي حل المشكلات التي تواجهم في ظل التقدم الرقمي الهائل. والثقافة الجيولوجية هي إحدي جوانب التقافة العلمية التي تهدف إلى تتمية علوم الحياة والأرض لدى المتعلمين وتزويدههم بقدر وافر من المعارف والقيم حول طبيعة الأرض والبيئة ومشكلاتها وكيفية التغلب

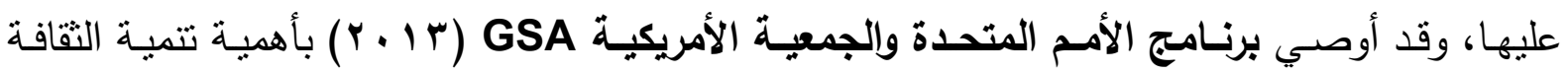
الجيولوجية للأطفال عن طريق فهم موارد الأرض من مياه وتربـة وكيفية إدارتها وتعزيزها والحفاظ عليها بالثكل الأمثل، وتعلمهم كيفية الوقايـة من المخاطر المحتملة للعمليات الارضية كالزلازل والفيضـانات، بالإضـافة إلـي غرس روح الأستكثـاف لديهم لكل مستخرج من الأرض وكيفيـة إستفادة دول العـالم منـه .(Sommer, K, 2014, 1-3)

وترى الباحثة ضـرورة وجود مصدر علمي موثُق يرجع لـه الأطفال في أي وقت للحصـول علي المعرفـة العلميـة الخاصـة بالمجـال الجيولـوجي ويتـوافر فيـه عناصـر التشـويق والتفاعليـة المناسبة مـع خصـائص أطفـال الروضــة الـذين لـديهم الثـغف والإثـارة بمشـاهدة أفـلام الكرتون والقصـص المصسورة المتحركة بالإضـافة إلى الألعـاب الإلكترونيـة والتي توفرهـا أجهزة الحاسـب الآلي، وبالتالي فـإن إعداد وتوظيف الكتب الرقمية التفاعلية وإستخدامها بطريقة نزبوية تؤثر في معرفة ومهارات وسلوكيات الأطفال تجاه المفاهيم الجيولوجية. ويُعذْ الكتاب الرقمي وسيط ثقافي تربوي مناسب لإكتساب المفاهيم الجيولوجية للأطفال، مثل الكتاب الورقي ولكنه يتميز عنه بإمكانيته في دمج جميع عناصر الوسائط المتعددة من نصوص وصور ثابتة ومتحركة ولقطات فيديو بالإضـافة إلى الصـوت المتزامن مـع تلك العناصر ممـا يثير الطفل لإكتساب المعلومات والمعارف الجيولوجية مع القدرة على تحكمه في صفحات الكتاب وممارسة التطبيقات الرقمية المرتبطة بتلك المفاهيم.

(") د. نورهان محمد بهجت أنور : مدرس بقسم العلوم الأساسية- كلية التربية للطفولة المبكرة - جامعة القاهرة. 
(Gloria Yi-Ming \& Chin-Chung, etal., وأكدت دراسـة جلوريا وشين وآخرون (2016 أن الكتب الرقمية التفاعلية تعد الأكثر مناسبة لتتمية المفاهيم العلمية حيث يتم توظيف القصص واتص التفاعلية فيها والتي توفر الحروف والكلمات المرتبطة بالتعزيز والملاحظات والتغذية الراجعة، فتتمي قدرة أطفال الروضة على تحسين اللغة من خلال تتمية مهارة القراءة والإسنقبال الجيد للمعلومات الجيولوجية.

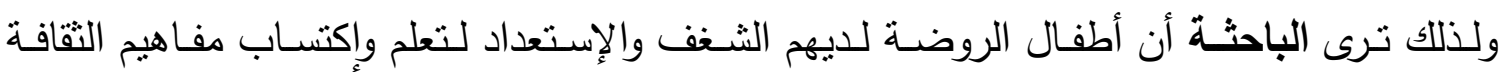

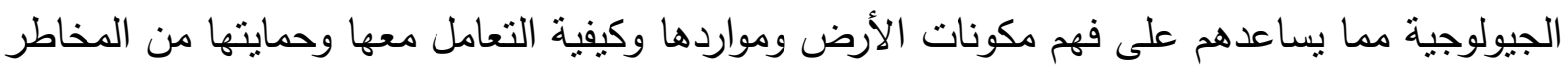

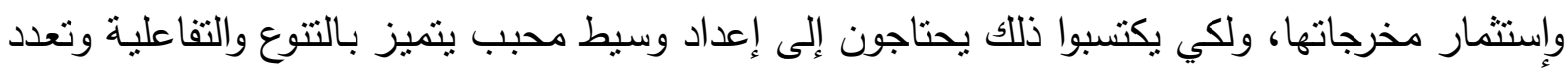
الأنشطة وطرق عرض المعلومات إلكترونياً وهذا ما يوفره الكتاب الرقمي التفاعلي. مشكلة البحث: لقد بدأ الإحساس بمشكلة البحث من خلال الخبرة العملية وملاحظة الأطفال أثناء الأثراف علي طالبات كلية التربية للطفولة المبكرة في مـادة التربية العملية (خارج الكلية بالروضـات)، حيث لوحظ قصور منهج الأطفال علي تتاول مفاهيم الثقافة الجيولوجية بداخل البرنامج اليومي مثل (تكوين الأرض لتربه

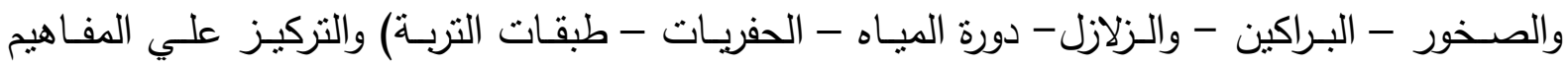

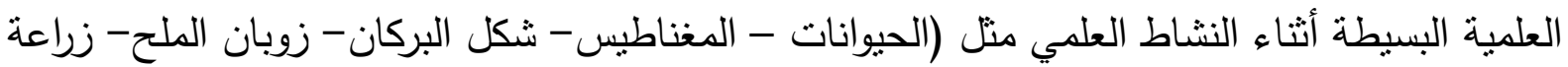
النباتات)، وتقديمها في شكل معلومات فقط دون الإهتمام بمهارات التقكير أو تكوين إتجاهات إيجابية تجاه العلوم الجيولوجية. كما لوحظ من خلال إجراء مقابلات مع بعض الأمهات لأطفال الروضة، أن الأطفال يسألون بشكل

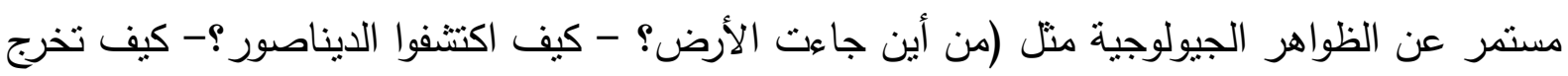

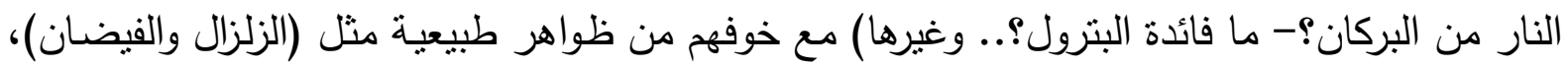
ولا يوجد إجابات لها وأن تركيز الروضة الأكبر علي الجوانب السلوكية والإجتماعية واللغوية.

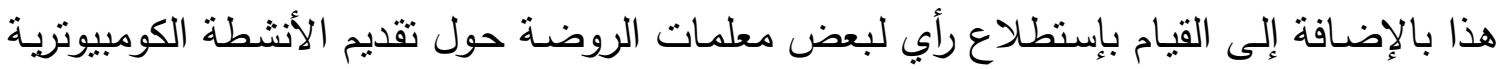

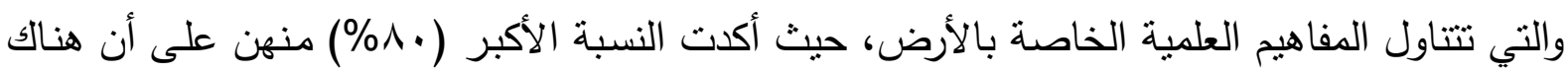
قصور في تقديم تللك الأنشطة والإهتمام بأنشطة القراءة والكتابة والحساب معتمدن على الكيه الكتاب الورقي،

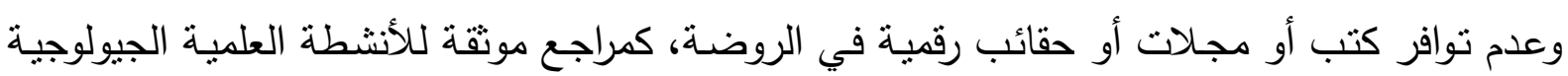
وذللك لضعف الموارد المادية. كما لوحظ في حدود علم الباحثة عدم وجود كتب رقمية تفاعلية يمكن أن تساهم في تتمية مفاهيم التقافة الجيولوجية لأطفال الروضة، ويالتالي تبلورت مشكلة البحث الحالي في السؤال الرئيسي التالي:

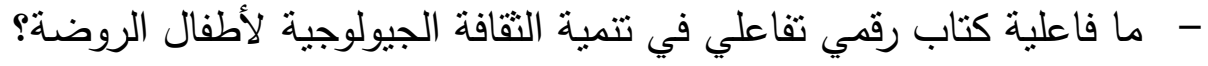




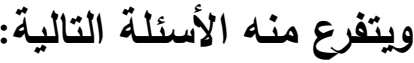

- - ما أبعاد ومفاهيم الثقافة الجيولوجية المناسبة لأطفال الروضة؟ الاهن: - ما مكونات الكتاب الرقمي التفاعلي وخطوات تصميمه؟ - ما دور أنشطة كتاب رقمي تفاعلي في تتمية مفاهيم الثقافة الجيولوجية لأطفال الروضةبه

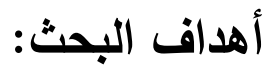

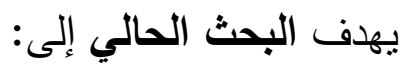

1- تحديد أبعاد الثقافة الجيولوجية والمفاهيم المرنبطة بها المناسبة لأطفال الروضة. r- تحديد مكونات الكتاب الرقمي التفاعلي المناسبة لتتمية التقافة الجيولوجية لأطفال الروضة. r- التحقق من إمكانية أنشطة كتاب رقمي تفاعلي في تتمية مفاهيم التقافة الجيولوجية لأطفال الروضة. ع - التحقق من تصميم مقياس رقمي تفاعلي لقياس الثقافة الجيولوجية لأطفال الروضة. أهمية البحث:

$$
\text { تتمثل أهمية البحث الحالي في أهمية نظرية وتطبيقية كالتالي: }
$$

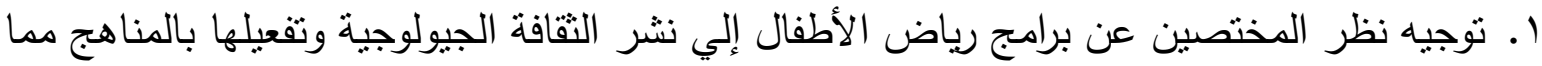

$$
\text { يسهم في تطوير البرامج التربوية وفقاً لمنطلبات الثقافة العلمية الحالية. }
$$

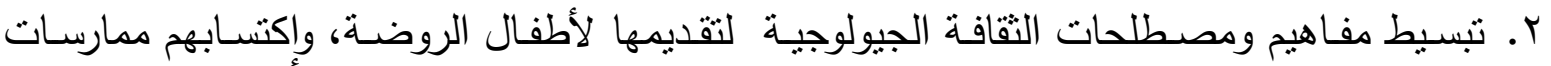
التفكير العلمي، وتكوين إتجاهات إيجابية عنها مها يساعدهم على فهم القضـايا المتعلقة بالبيئة المحيطة بهم ومحاولة حل مشكلاتها.

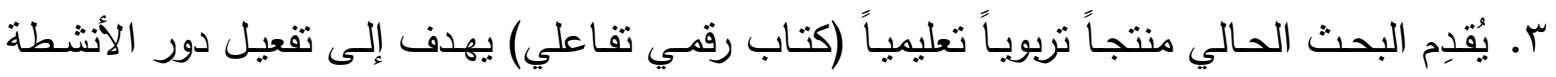
الإلكترونية الني تسهم بدورها في تتمية مفاهيم النقافة الجيولوجية لأطفال الروضية.

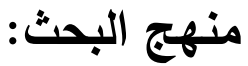
تَبنى البحث الحالي المنهج شبه التجريبي Semi- Experimental Method لمناسبته لطبيعته وذلك باستخدام التصميم التجريبى ذو المجموعنين (التجريبية - الضابطة) لـعرفة أثر المتغير المستقل (كتاب رقمي تفاعلي) على المتغير التابع (التقافة الجيولوجية). فروض البحث: ا ـ توجد فروق ذات دلالة إحصائية بين متوسطى رتب درجات أطفال المجموعة التجريبية قبل تطبيق

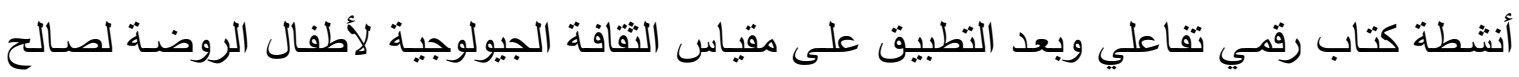
القياس البعدى. 
r. توجد فروق دالـة إحصـائيا بين متوسطي درجـات أطفال المجموعـة التجريبيـة وأطفال المجموعـة الضابطة فى القياس البعدى، لتطبيق أنشطة كتاب رقمي تفاعلي على مقياس التقافة الجيولوجية

لأطفال الروضة لصالح المجموعة التجريبية. مصطلحات البحث: وقد عرفتها الباحثة إجرائياً كالتالي: ا-كتاب رقمي تفاعلي Interactive Digital Book: هو عبارة عن أسطوانة ددمجة تحتوي على إنى

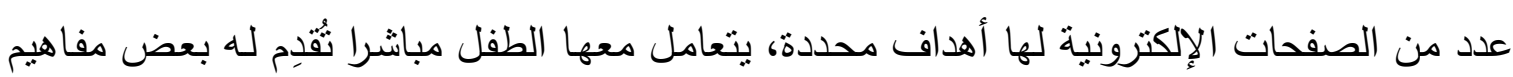

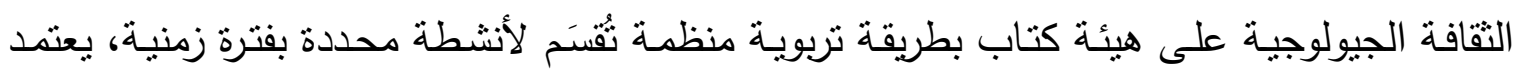

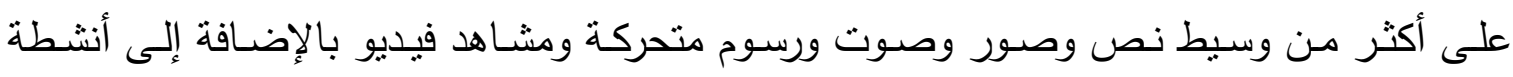
تطبيقية وألعاب تفاعلية مستمرة لكل مفهوم تقيس مدى استيعاب الطفل لمحتوي الكتاب.

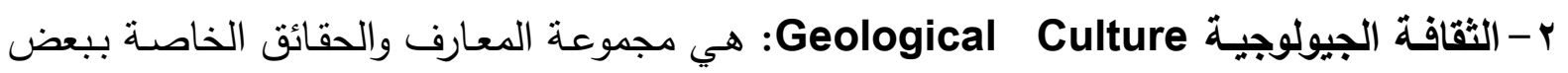

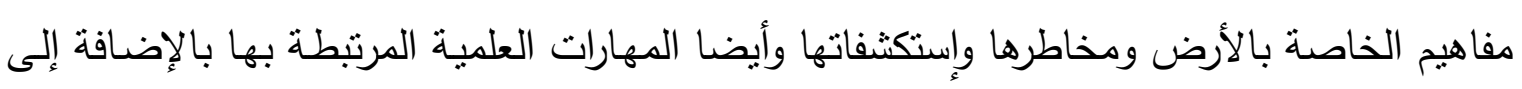
الإتجاهات والقيم السلوكية الإيجابية نحو العلوم الجيولوجية التي يمكن قياسها لأطفال الروضة ولئة

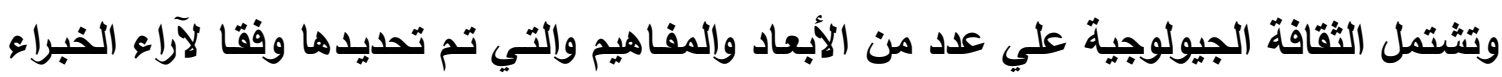
والمحكمين علي النحو التالي: - البعد الأول/ بعد الأرض: وهو إكتساب الأطفال معلومات عن شكل الأرض وطريقة تكونها وأثنكال

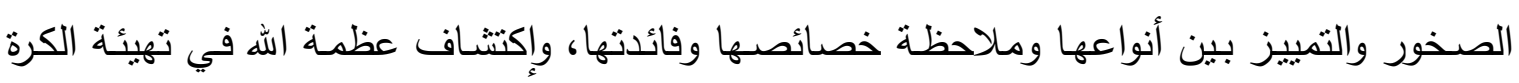

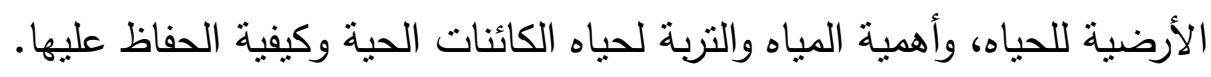

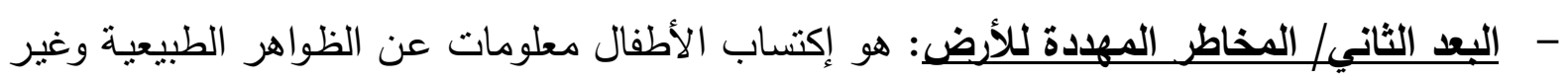

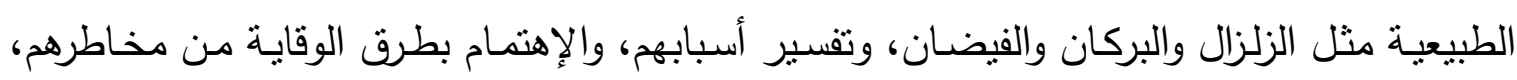

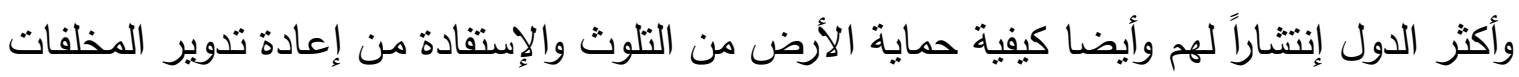

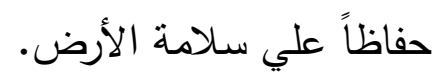
- البعد الثالث/ الأستكثـافات الأرضية: هو إكتساب الأطفال معلومات عن المناجم وأنواعها وطرق

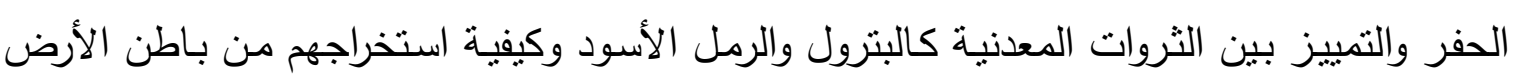

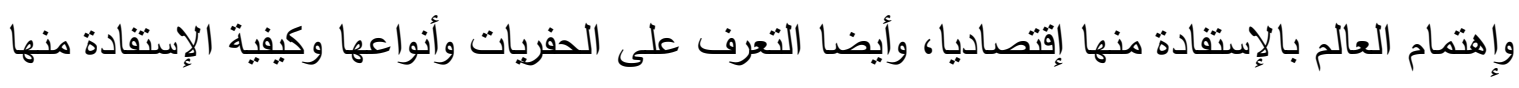

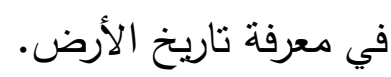
ץ- أطفـال الروضـة Kindergarten Children: هو الأطفال الملتحقين بمرحلة برياض الأطفال

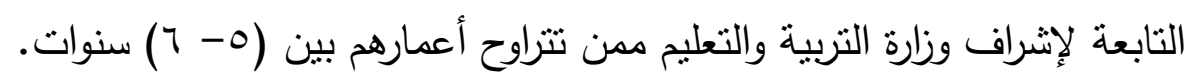


الإطار النظري ودراسات سابقة:

سوف يتتاول الإطار النظري محورين رئيسيين وهما :

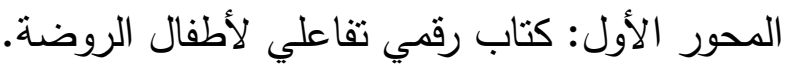

المحور الثاني: الثقافة الجيولوجية لأطفال الروضية.

\section{المحور الأول: كتاب رقمي تفاعلي لأطفال الروضة.}

أولاً: الكتاب الرقمي التفاعلي:

يُعد الكتاب الرقمي إحدى أهم المكونات الرئيسية للتعلم الإلكتروني لأطفال الروضة حيث يُستخدَم

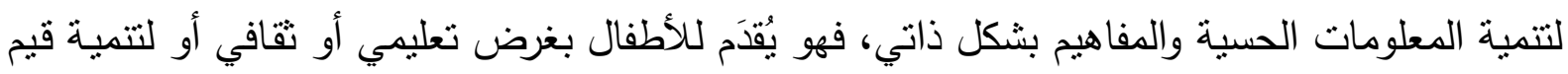

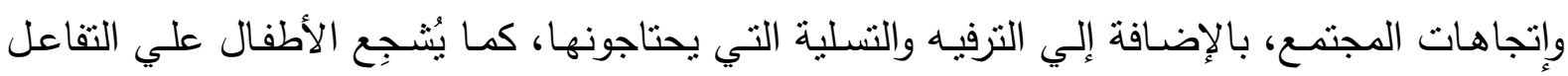

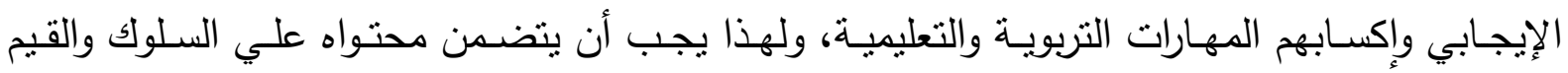

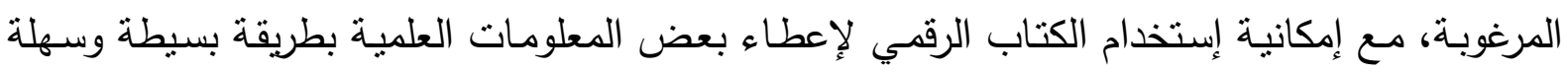

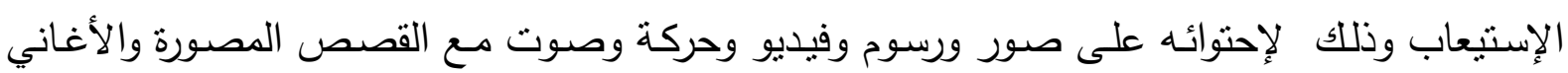

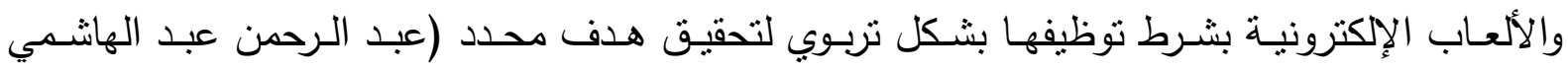

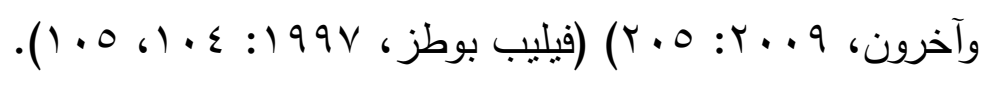

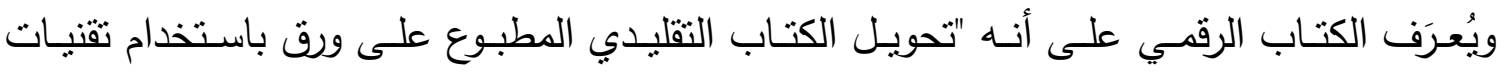

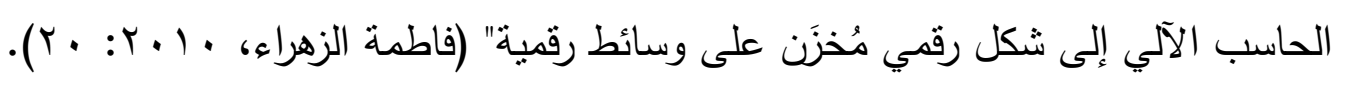

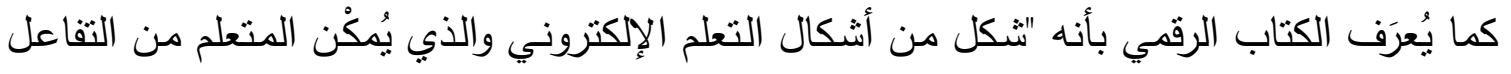

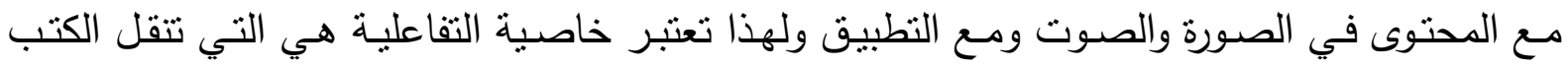

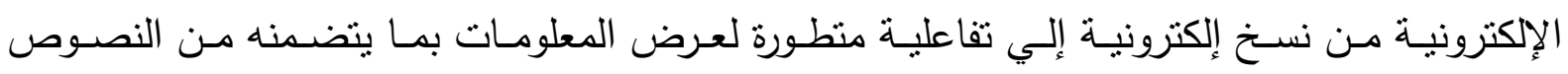
والرسومات والأثكال والصور والحركة والمؤثرات الصوتية واللقطات الفيليمة علي هيئة كتاب متكامل يتن

نسخه علي الأقراص المدمجة" (Nadia Mana\& Ornella Mich, 2013:14). وقد عَرفت الباحثة الكتاب الرقمي التفاعلي لأطفال الروضة إجرائياً بأنه أسطوانة مدمجة تحتوي

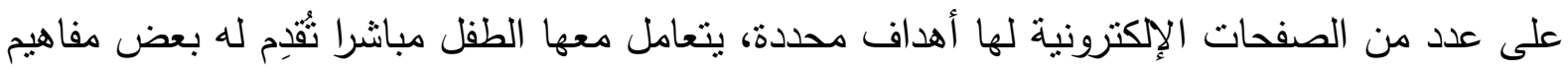

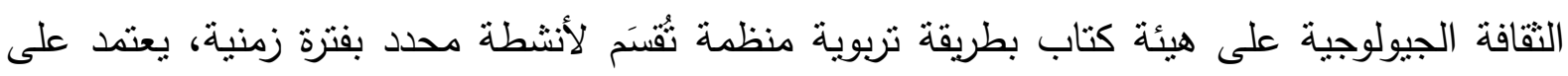

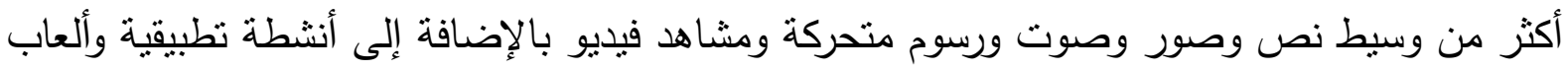
تفاعلية مستمرة لكل مفهوم تقيس مدى استيعاب الطفل لمحتوي الكتاب. ثُانياً: الخصائص المميزة لكتاب الطقل الرقمي التفاعلي:

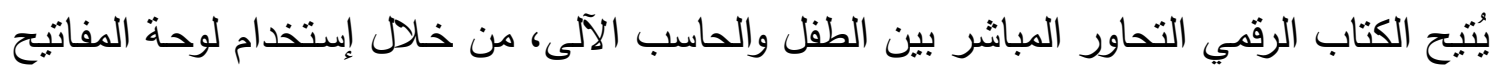

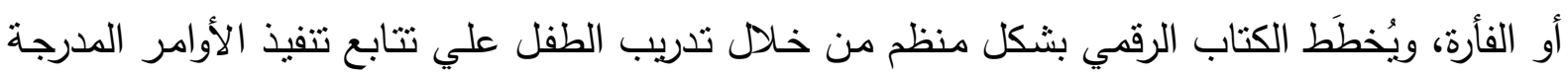




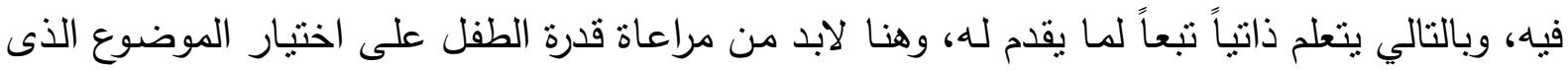

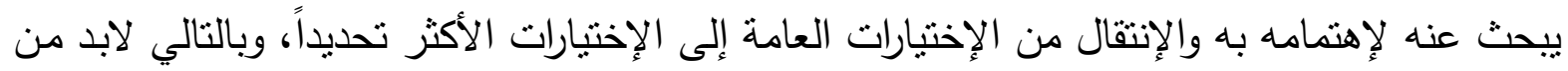

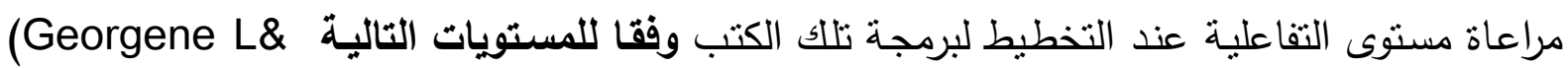
:Collen E\& Gabrielle A, 2016: 55- 56) - التفاعل المباشر: أى الاعتماد على اسلوب الحديث المباشر مع الطفل وكأن المحادثة بين طرفين فى شكل اسئلة مصاغة بشكل بسيط تهدف إلى إثارة فكره وإعمال عقله.

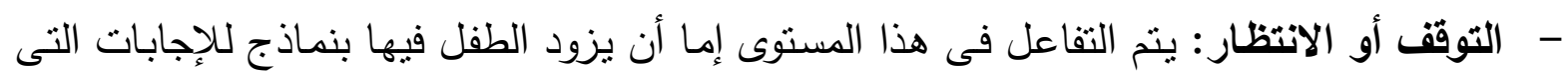

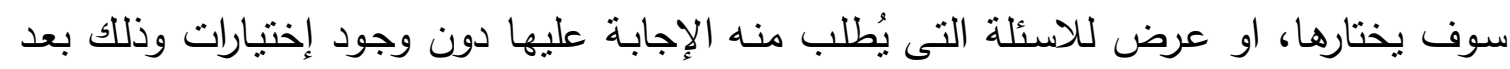

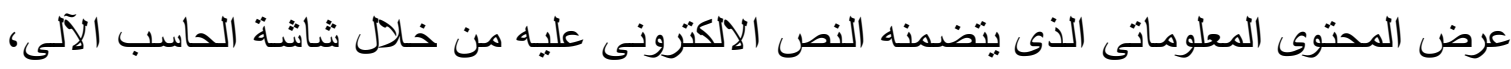
والذى قد يكون مثلا مجموعة من المفاهيم العامة، ثم يتم توجيه الطفل بعد ذلك الى الى مكان الأسئلة

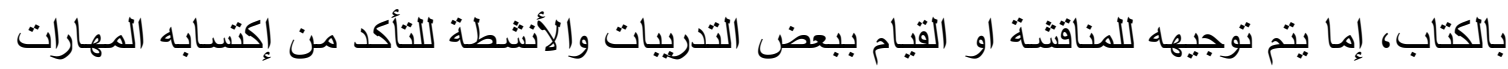
والخبرات المناسبة والتى من المفروض أن يكتسبها ويعيها من النص الآكترونى الذى عرض على عليه.

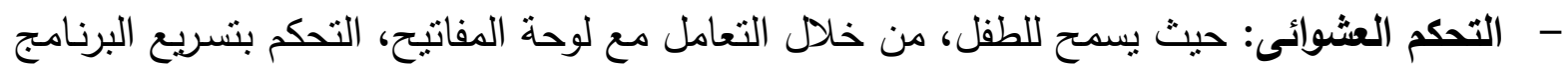

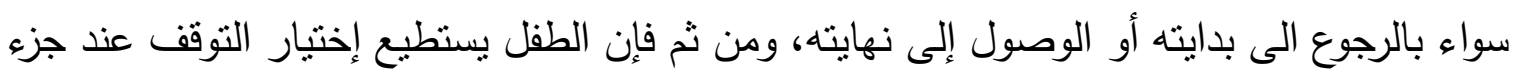

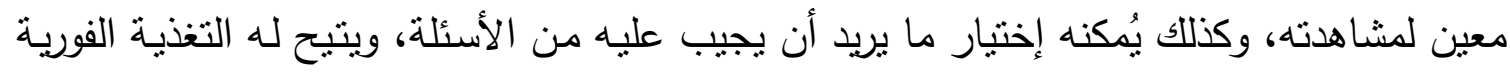

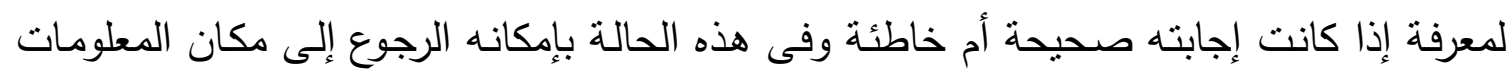
ومعرفة الإجابة الصحيحة بنفسه. يُطبق البحث الحسالى المستوى العشوائي للتفاعل داخل كتابه الرقمي ليستطيع الطفل التحكم فيهـ بشكل فعال ومرن لإكتساب مفاهيم التقافة الجيولوجية. ويَشمل كتاب الطفل الرقمي التفاعلي على مجموعة من المميزات هي كالتالي:

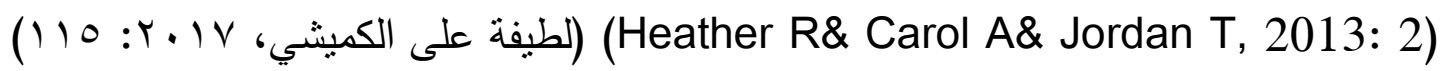
- توفير مساحة تخزين كبيرة للمعلومات المقدمة للطفل بتكاليف منخفضة داخل المكتبات. - - إمكانية التعامل مع النصوص والصور والأصوات فى وقت واحد مما يحدث تجاوباً وتفاعلاً بينها وبين الطفل.

- سهولة إستخدامها من قبل الأطفال بأنفسهم، فهى ثُهيى له المناخ التربوى والتعليمى السليم.

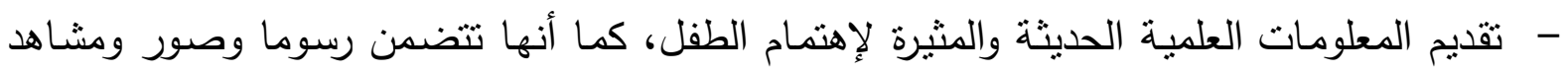
ساكنة ومتحركة وجداول وإيضاحات نساعد الطفل على فهم واستيعاب المعلومات.

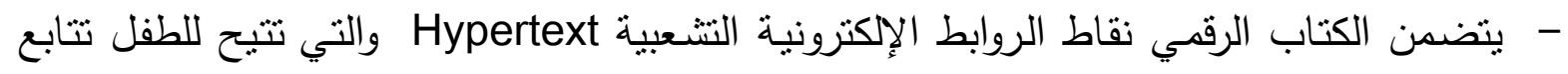
وتنلسل الأفكار الواردة فى النص، والإنتقال إلى نصوص أخرى لزيادة المعلومات التي ينتاولها 
- يتضمن الكتاب الرقمي برامج تعليمية يمكن عرضها وفقاً لاحتياجات الطفل فتُسسر له تغبير أو إعادة تتكيل المعلومات بما يناسب المهارة المعرفية لايه، وتتيح له إمكانية التحكم فى تتاول هذه المعلومات مما يؤدى إلى زيادة التفاعل بينه وبين محتوى البرنامج. - يُقدِم الكتاب الرقمي المعلومات بطريقة حية تحاكى الواقع المحسوس المشاهد بحيث ثوفر إمكانية تحويل المعلومات من الثكل المجرد إلى الثكل الحي، وإكتساب القدرة على التنبؤ والتفسير والتدريب على التقكير المنطقى، وإكتساب مهارة التحليل والتركيب، وتصميم التجارب بأمان. وبالتالي تؤكد الباحثة أن الكتاب الرقمي للطفل يدعم تتميـة المهارات المعرفية والمهارية والوجدانية لديه بشكل تلقائي مباشـر، وهنا بأني دور التربوي في توظيف إمكانات الكتاب الرقمي المتعددة بشكل فعـال لإكتسـابه مفـاهيم العلوم الجيولوجيـة بشكل متـدرج مـن خـلال معرفة المعلومـة والتفاعل معها ثم تطبيقها، وكل هذا يتم بشكل فردي.

ثالثًا: أهمية إعداد كتاب رقمي تفاعلي لأطفال الروضة:

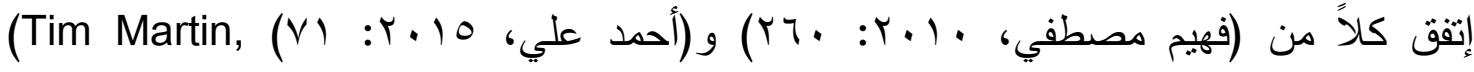
2019: 1-3)

- يُساعد الكتاب الرقمي على تتمية مهارة القراءة لدى الطفل من خلال قراءة التعليمات وإتباعها، فنتمو قدرتـه على تحليـل وتقسـير النصـوص المقـروءة، وفهم العلاقـة بـين الجمـل، وتحليـل المشـكلات، والتشجيع على الابتكار والإبداع. - يراعى الكتاب الرقمي الفروق الفرديـة بين الأطفال من خـلا المستويات المتعددة للتفاعل وطرق العرض المختلفة فيخرج بذلك من التلقين إلى البحث وكيفية الوصسول إلى المعلومـة لتحقيق نظريـة (Hendrik Knoche,et al., التعليم الذاتى، وفقاً لما أوصت به دراسة هندريك كنوشيه وآخرون

- تتمية قدرة الطفل على التمييز بين ما هو حقيقي وغير حقيقى، والقدرة على المرونة فى طرح الأسئلة، وبحثةه عن الأسباب وإستتناج النتائج. - - إتاحة الفرصة للطفل لتحديث المعلومات المقدمة من خلال الكتاب الرقمي وتحويل التركيز من المعلومة المباشرة إلى المهارات المعرفية فيقي أثز التعلم. - - يقدم الكتاب الرقمي للطفل المتفوق حافزا للإستمرا في التفوق ويمنح الطفل الفرصة من أجل تتمية قدرته علي الفهم والتذكر والإستيعاب. - - إناحة فرصة الممارسة الكافية واللازمة لإتقان المهارات المختلفة. وتتير الباحثة إلى ان الكتاب الرقمي يُشجع الطفل علي تتمية نقته بنفسه من خلال تحري الدقة وتجنب الوقوع في الخطأ، ومساعدته على اكتثاف معلومات وحقائق جديدة بنفسه وهذا يجعله يعتمد علي 
نفسه مستقبلاً كأساس لمبدأ التعلم الذاتي، كما أنه يراعي مبادئ التعلم الفعال الذي يساعد علي إثارة

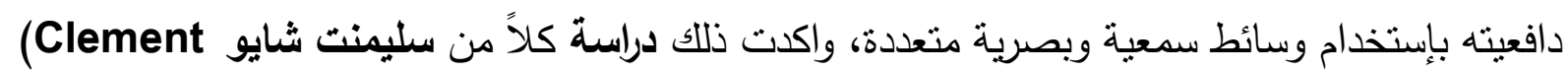

(Betty Sargeant, 2015) وبيتي سارجين L. Chau, 2014) لإيعاً: مكونات الكتاب الرقمي التفاعلي:

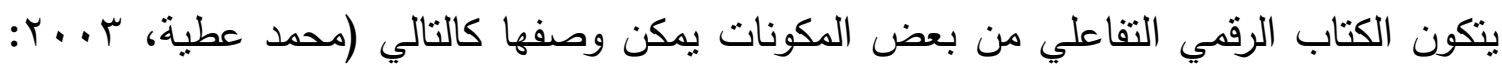

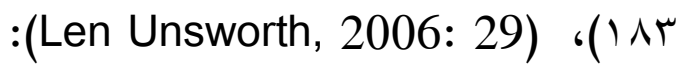
- النص: وهو المكون الرئيسي عند تقديم المعلومات وربط عناصر الوسائط المتعددة بالبرنامج،

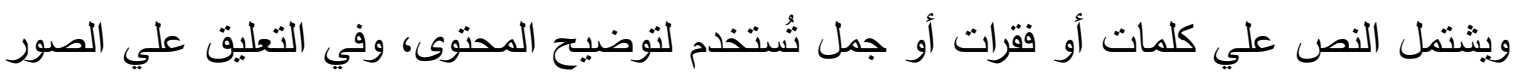
والرسوم المستخذمة في البرنامج كما يُستخذَم في تقديم التفسيرات والتغذية الراجعة والعناوين والقوائم والتجول.

" الصوت: وهو الصوت الثنارح للعناصر أو أصوات التعزيز أو موسيقي ومؤثرات صوتية وهي تُتخدم في التعبير عن المواقف الدختلفة وإضفاء عنصر الواقعية للإحساس بالأحداث والأماكن

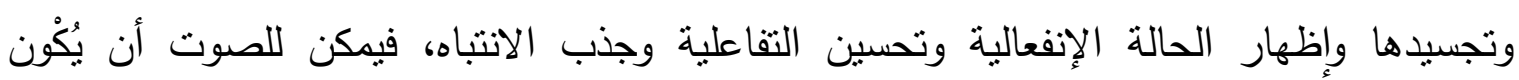

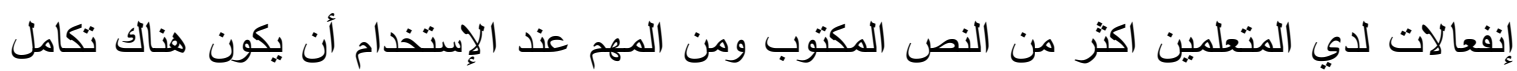
للصوت مع الوسائط الأخرى في إنجاز المهام المطلوبة.

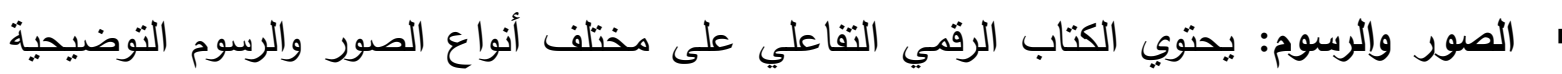

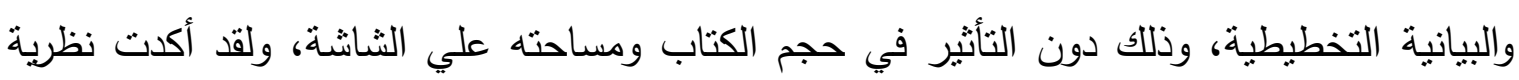
التشفير الثنائي أن تمثيل المعلومات في شكل بصري ولفظي يتم تذكرها بصورة أفضل من المعلومات التي تُشتَل في شكل واحد.

وللصور خمس وظائف تعليمية تقع نلك الوظائف في بعدين الأول وجداني ويتضمن (الثكل والتحفيز) والثاني إدراكي ويتضمن (جذب الانتباه والتقديم والممارسة) وتطبيق وظائف الصور في فئي ولئي الكتاب للطفل يزيد من دافعية التعلم.

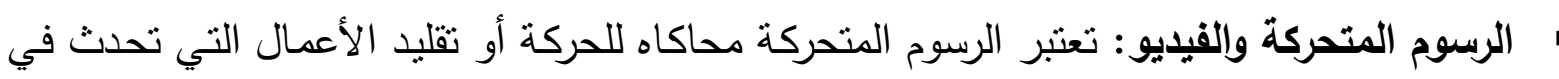

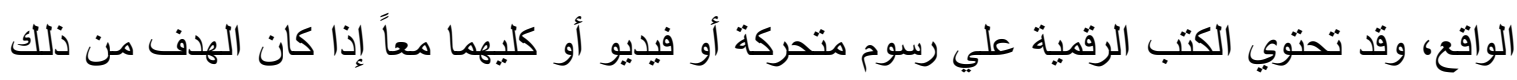

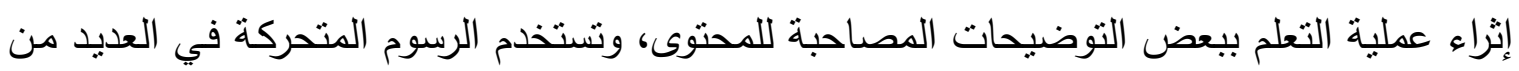

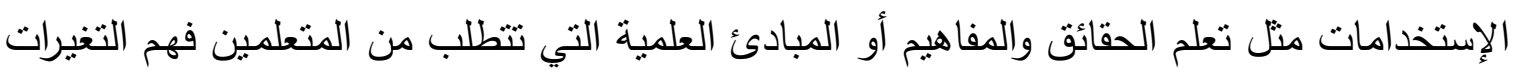

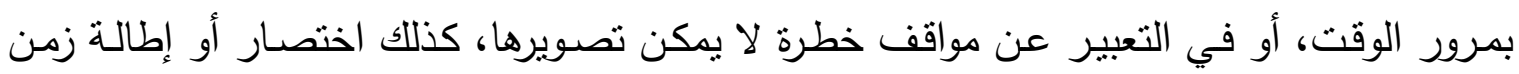

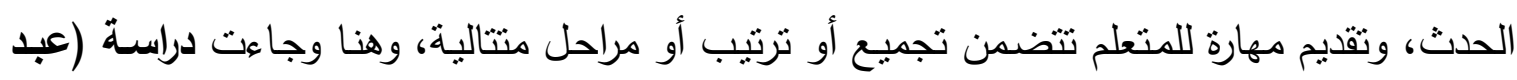

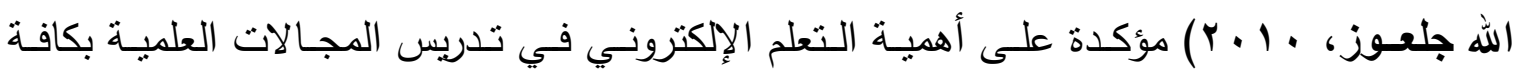


• أنظمـة الإبحـار : يتيح للكتاب الرقمي استخدام أنماط مختلفة مـ التجول داخله كالبنيـة الثبكية

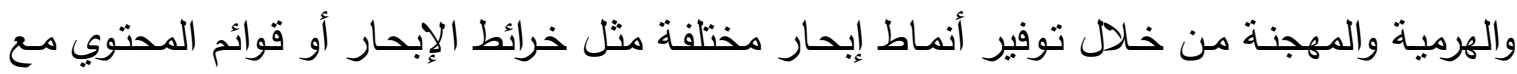
الروابط الفائقة.

الوصلات الفائقة: نستخدم للربط بين عناصر الكتاب الرقمي وصفحاته ومكوناته ويراعى فيها أن تكون بلون مختلف عن باقي عناصر النص داخل الكتاب. وهناك مجموعة من المعايير التي يجب تواقرها فى التصاميم الرقمية للأطفال وذلك تحقيقاً للجودة الثاملة فى التطم (Johnson\& Charlotte, 2012: 121-128)، تلخصها الباحثة كالتالي: 1 - - تدعيم التعلم الذاتي للطفل. Y- ينبغى أن يوفر للمتعلم إمكانية الاتصال المتزامن. r- ينبخى أن يتوافر فى أشكال مختلفة وأن يمكن المستخدم من تتفيذ بعض الأنشطة على جهاز الكمبيوتز بسهولة ويسر .

ع - يتيح للمتعلم الإبداع والتفكير ، حيث توصلت دراسـة (علياء سمير، 1 1 ــץ) في أهمية البرامج الإلكترونية في تتمية العمليات المعرفية للأطفال. 0- التعلم من خلال انشطة محببه للطفل ذاته. ؟- توفير حرية البيئة التعليمية للمتعلم من حيث الدخول والخروج من البرامج في أي وقت. - V يشجع المتعلم على المحاولة والخطأ 1- الاهتمام بكل متعلم على حدة ووفقاً لظروفه التعليمية. نموزج تصميم الكتاب الرقمي التفاعلي: بعد دراسة العديد من نماذج التصميم التعليمي للكتب الرقمية مثل/ نموزج جيورلد كمب ونموزج عبد اللطيف الجزار ونموزج محمد عطية الخميس (حسن الباتع محمد، السيد عبد المولي، ؟ ا ـ ؟: با (1- 79 ())، إستخلص البحث الحالي الخطوات التالية لتصميم الكتاب الرقمي التفاعلي الخاص به، كما هو موضح في شكل (1): 


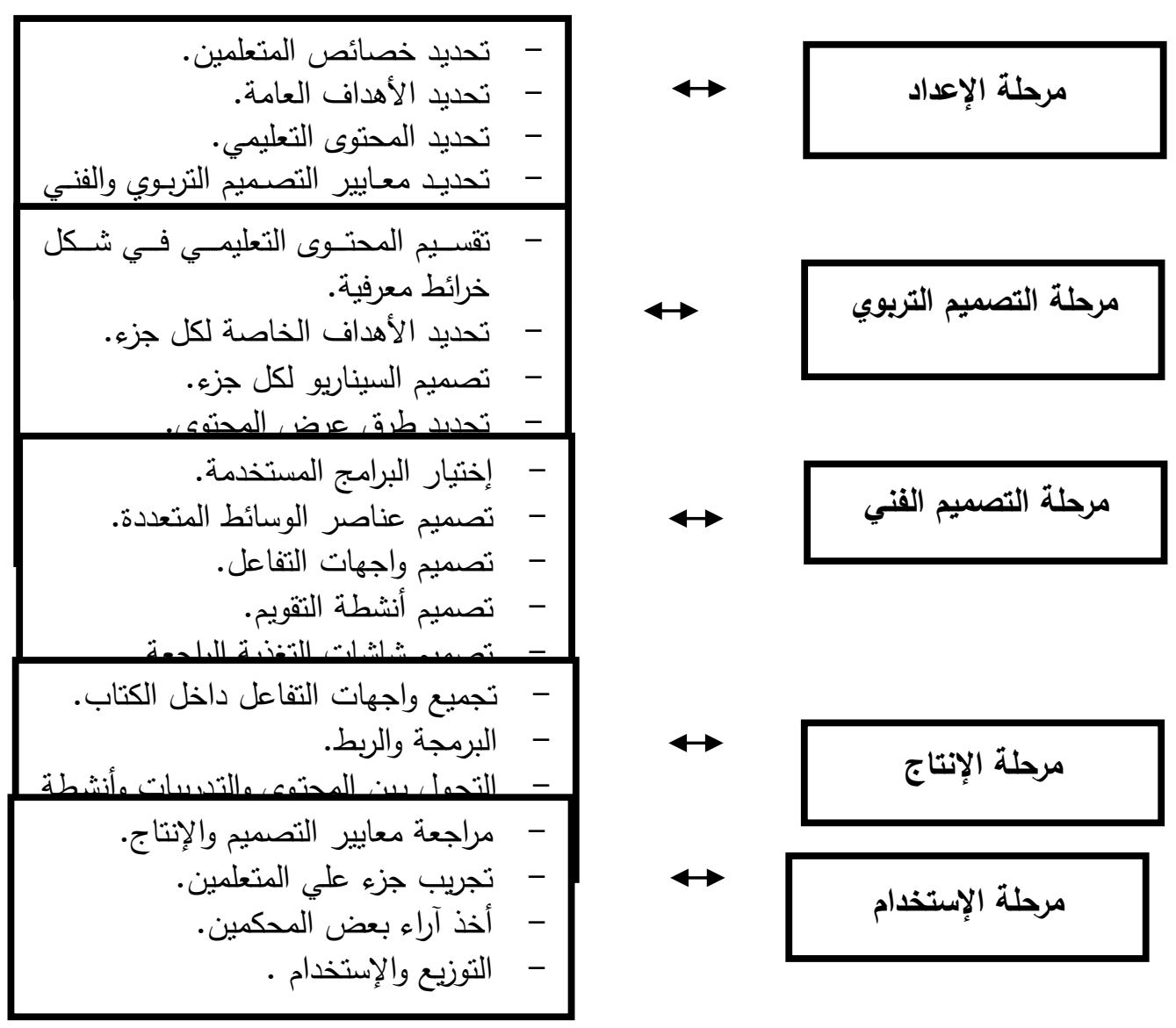

شكل (1)

خطوات التصميم التعليمي لإعداد الكتاب الرقمي التفاعلي الحالي

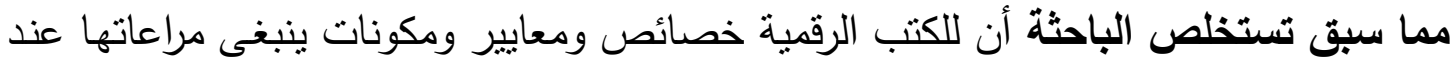

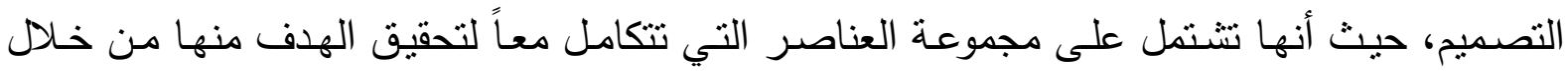

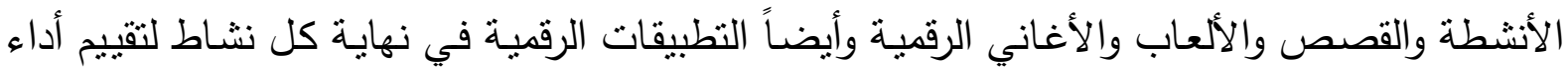
الطفل، والتي تنسط بدورها تتمية الدفاهيم العلمية، لذلك تم توظيف الكتاب الرقمي التفاعلي كأحد الوسائط الهامة في تتمية الثقافة الجيولوجية لأطفال الروضة. المحور الثاني: الثقافة الجيولوجية لأطفال الروضة. لألية. أولا: مفهوم الثقافة الجيولوجية: يُعَد مفهوم التقافة الجيولوجية إحدي أهم مجالات المعرفة العلمية التي يحتاجها الفرد ليواجه التقدم

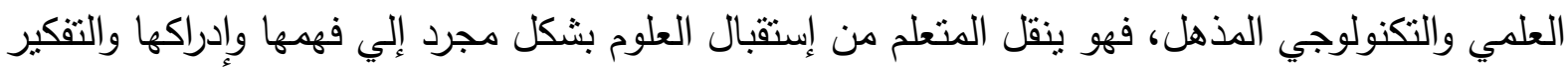

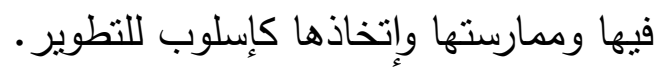

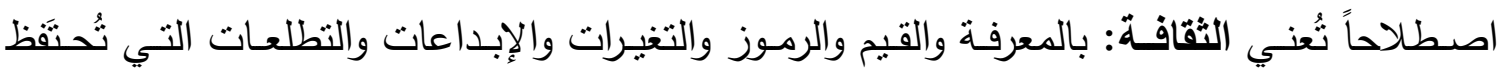

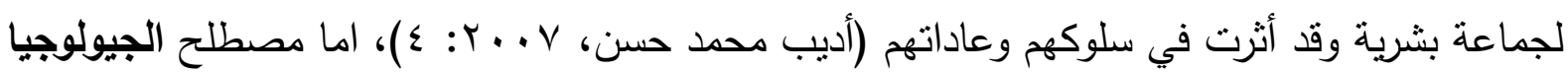


فهو مشتق من قسمين الأول وهو جيو Geo والذي يعني أرض، والمقطع الثاني هو لهوجي Logy

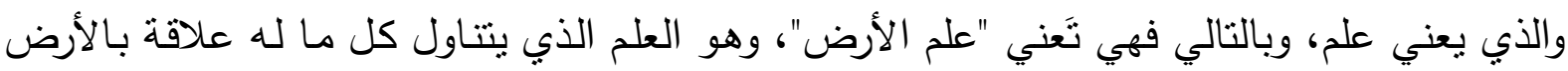

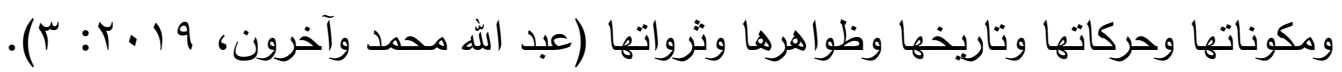
وقد تتاول مؤتمر جيو ايطاليا (2011- Geo Italia,2009) الثقافة الجيولوجية بأنها تُعني

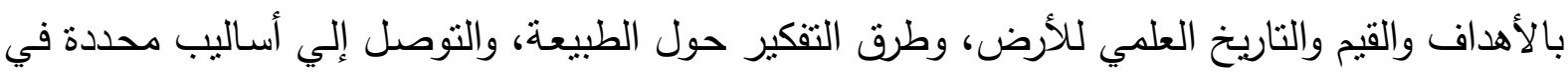

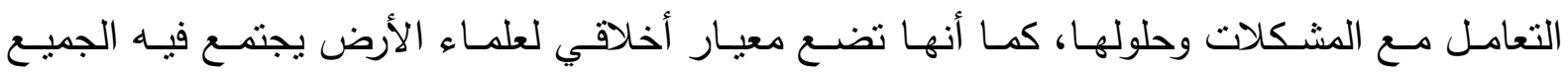
.(Giuseppe Capua, 2009-2011) وتُعني الثقافة الجيولوجية للمتعلم بالروئة البصرية للتكوينات والتضاريس الخاصة بالأرض ومعرفة الوقت الجيولوجي لها والتحولات والتغيرات التي طرأت عليها عبر العصور ، فينمو لديهم قدرات التفكير بلهيه

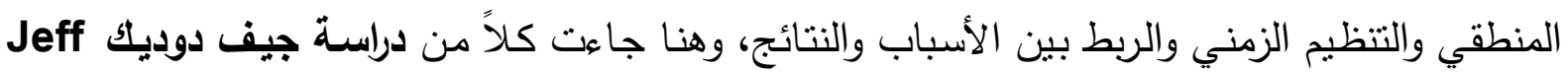

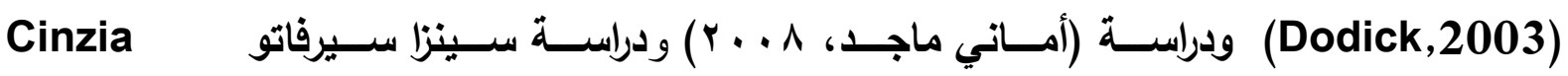
(Cervato,2012) مؤكدين علي أهمية تتمية العوامل المعرفية والحس الجيولوجي للمتعلمين في مرحلة الطفولة.

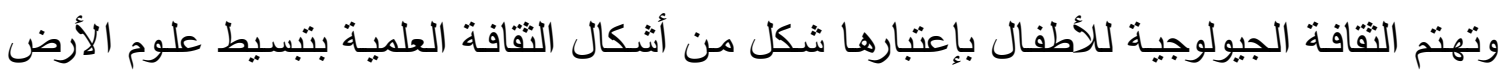
لايهه، ومنها نشأة الأرض وبنيتها وتاريخ تطورها والظواهر الطبيعية التي تؤثر عليها كالزلازل والبراكين

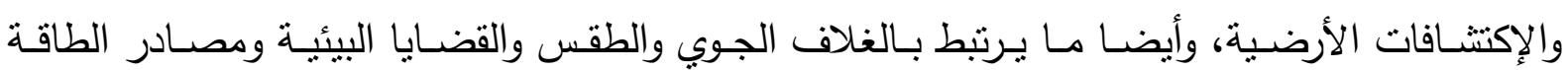
والأحياء ودورات الحياه للكائنات الحية عبر الزمن (Sutton,C.R.,2015:220).

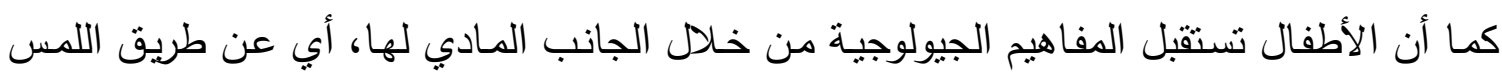

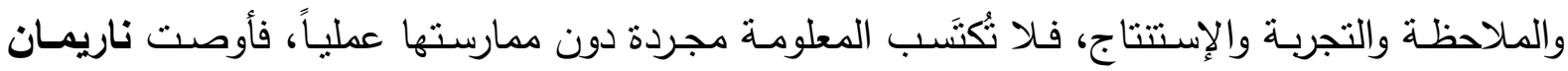

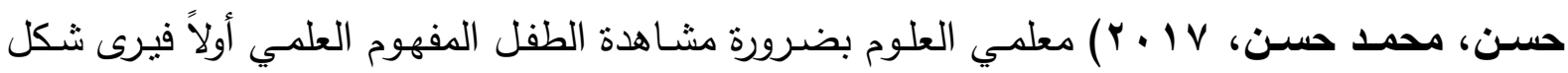
البركان مثناً في كتاب ثم يثاهد تجربة عملية أثناء إنفجاره، وذلك ليكتمل إستيعابه للمفهوم ككل.

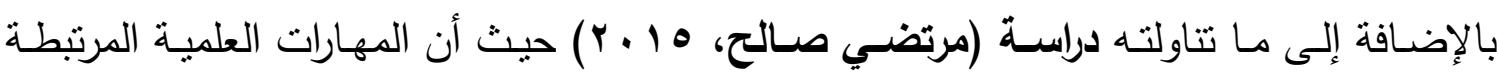
بالجيولوجيا التي يكتسبها الطفل تساعده علي تتمية قدرات التفكير العلمي لديه، كالتمييز بين أثنكال الصخور وتفسير ظهور النباتات من الأرض وأيضاً إكتشاف طرق إستخراج الغاز والبترول والمبات لفياه

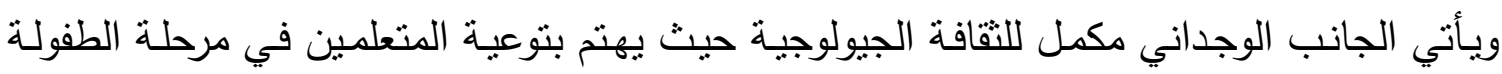

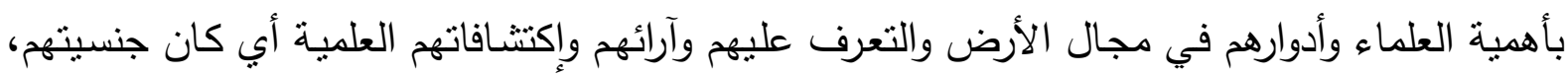

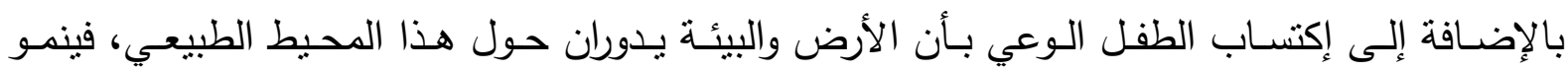

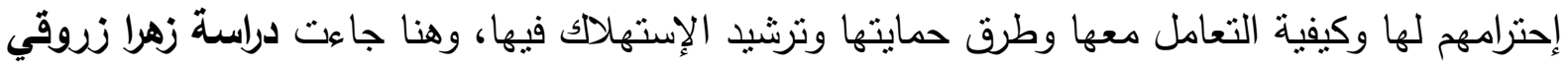
وآخرون (Zahra Zerrouqi, et al., 2016) مؤكدة علي أن علوم الحياه والأرض من أهم مجالات التربية البيئية الضرورية لتتمية وعي المتعلم بالجوانب الرئيسية للحفاظ علي البيئة وحل مشكلاتها. 


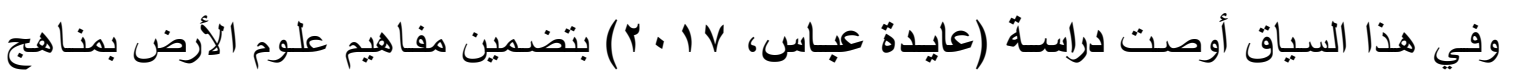

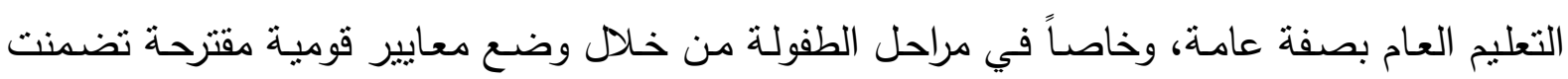

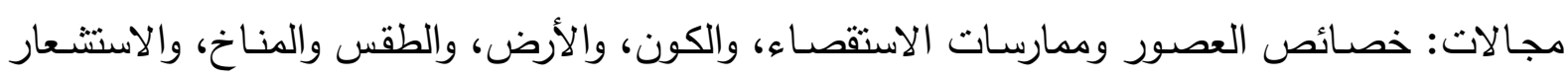

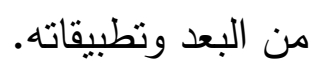

وتؤكد الباحثة على أن النقافة الجيولوجية تبدأ من معرفة المتعلم بالمعلومات والمعارف العلمية حول الجيولوجيا فهي ضرورية لتوسعة مجال إدراكهم للأرض المحيطة بهم، ثم ممارستهم للمهارات العلمينة حول تلك المفاهيم، ومن ثم تكوين إتجاه إيجابي نحوها وتقديرها والحفاظ علي البيئة حولهم، كما هو

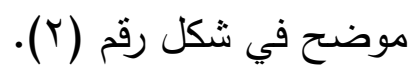

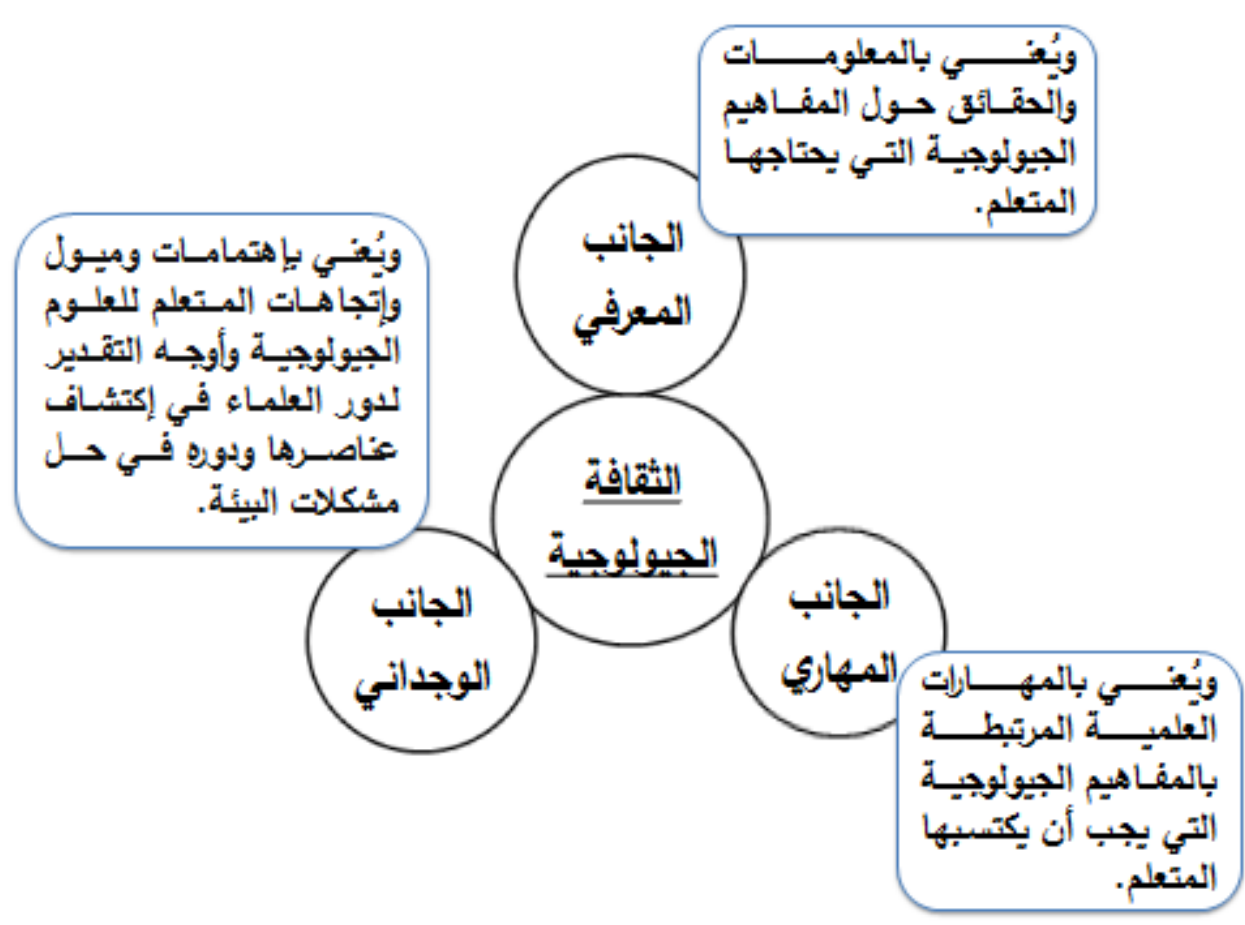

شكل (r)

رسم توضيحي لجوانب الثقافة الجيولوجية (من وجهة نظر البحث الحالي)

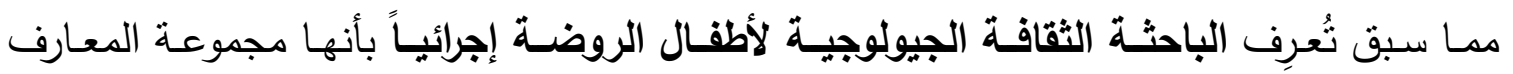

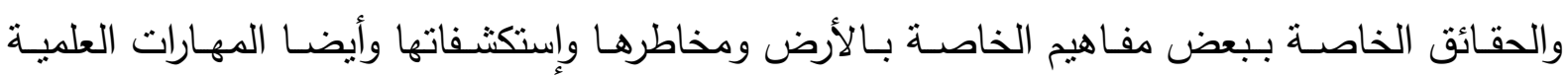

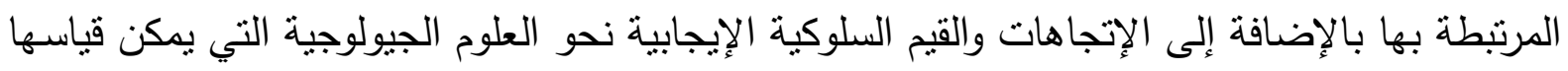
لأطفال الروضة.

ثانياً: النظريات التريوية لمفهوم الثقافة الجيولوجية لأطفال الروضة:

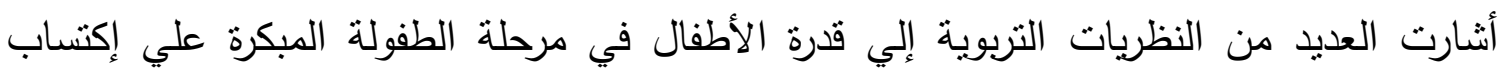
المفاهيم العلمية وممارسة المهارات العلمية المرتبطة بها وتكوين إتجاه إيجابي نحوها، وهذا يدل علي التئي إستعدادهم لتكوين الثقافة الجيولوجية. 
فيري فيجوتسكي أن المفاهيم العلمية المقدمة لطفل الروضة تتمو لديه إما نتيجة الإحتكاك اليومي

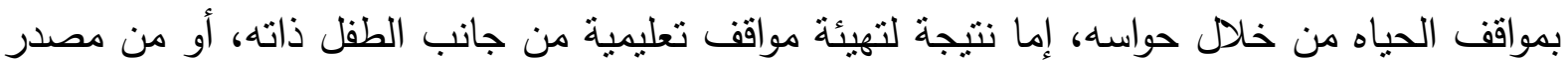
خارجي، وعلي الرغم من إختلاف الموقفين، إلا أنهما متكاملان.

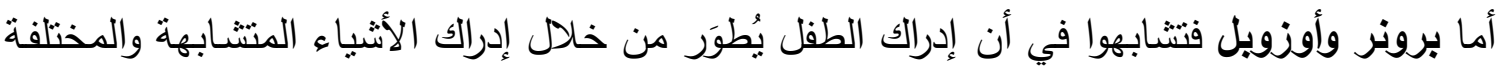
الموجودة بالفعل في بناءه المعرفي وما يقدم له من معلومات جديدة فيقوم بعمليات تصنيف متسلسلة لها، ويوجٍد العلاقات بينها لإستقراء المفهوم العام، فيحدث التعلم ذي المعني الذي يربط الطفل بحياته اليومية، وأضاف جانيه أنواع لتعلم الطفل كتعلم الحقائق والمعلومات وتعلم المبادئ وتعلم حل المشكلات.

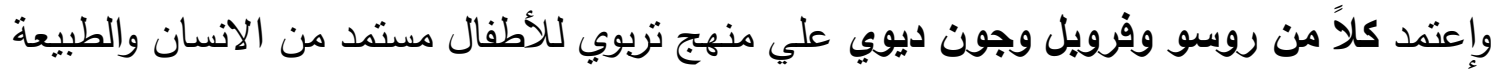

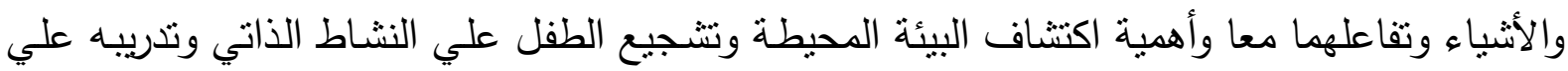

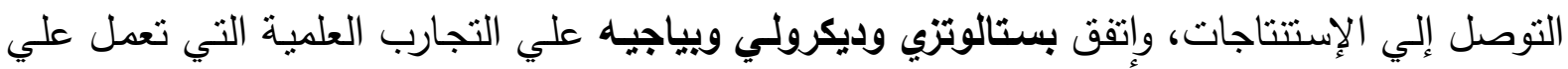

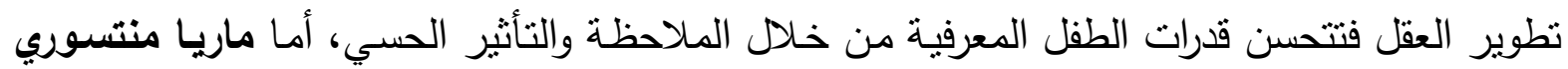
فاعتمدت علي معايير الاستخدام العلمي للحواس واكساب الطفل الخبرات التربوية من خلال أساليب عرض الأنشطة العلمية وتمكين الطفل من الربط بين الأثياء ومسمياتها وماهيتها. (منيرة العتيبى،

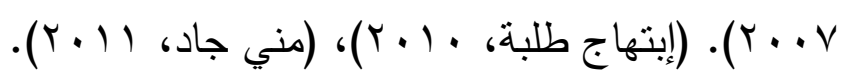

مما سبق إعتمدت الباحثة في إكتساب الاطفال مفاهيم النقافة الجيولوجية علي المشاهدة العفوية

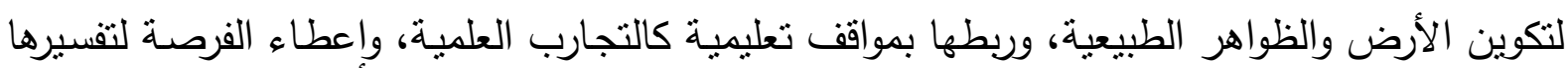
وكيفية التعامل مع موارد الأرض، وإكتثاف البيئة وطرق حمايتها. ثالثثاً: أهمية الثقافة الجيولوجية لأطفال الروضة:

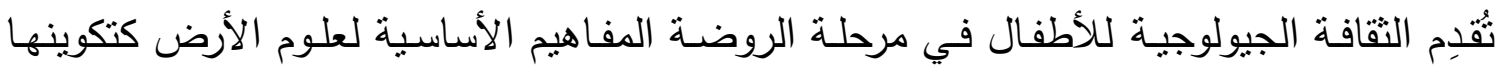

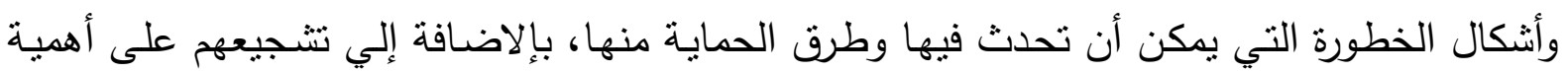

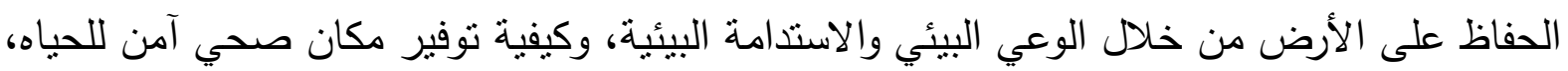

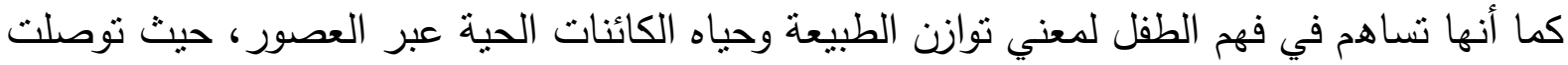
دراسـة سيلفيا بيبولوني (Silvia Peppoloni\& Giuseppe Di, 2012) إلي أن دراسة الثقافة الجيولوجية تساهم في نشر المعلومات العلمية الصحيحة كما توصل لها علماء الجيولوجيا، وذلك لبناء معرفي سليم للمتعلمين حول الظواهر الطبيعية وكيفية التعامل معها.

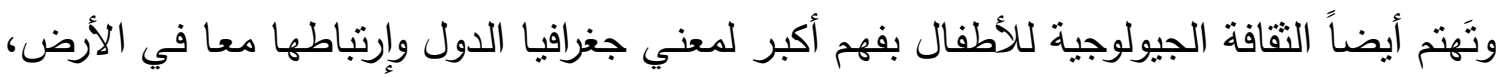

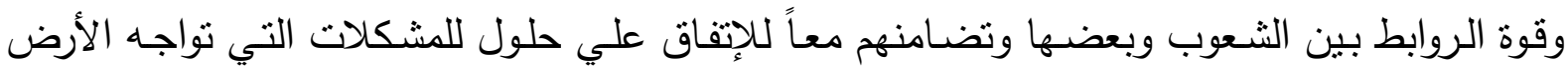

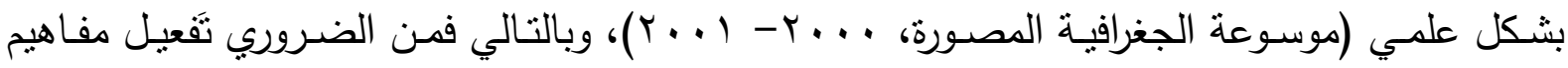

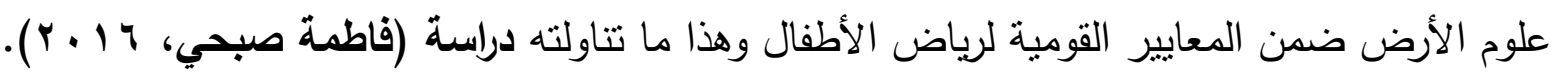


وأضـافت دراســة كـلاً مـن روجيـر ترينــ (Roger\&Trend,2007 )، ودراسـة شــارلز آلـوت

(Charles,R.Ault,2018)

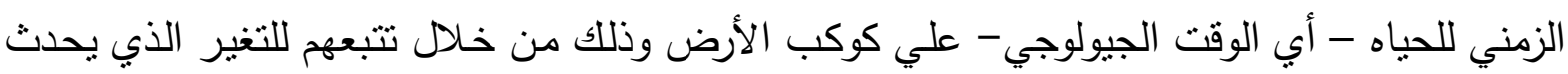

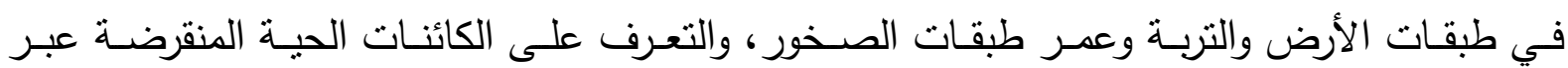

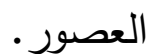

ويُككن للتقافة الجيولوجية أن تساهم في تغيير تعامل الأطفال مع البيئة المحيطة من خلال التغير

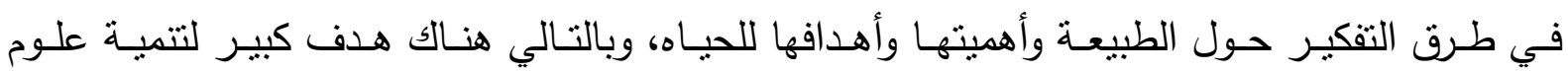
الجيولوجيا للأطفال وهي إعادة تتكيل القيم المرجعية وغرس الأخلاقيات حولها، وهذا يسمي بالأخلاقيات

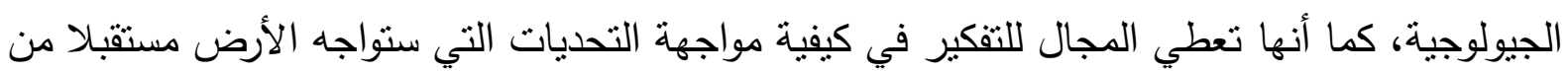

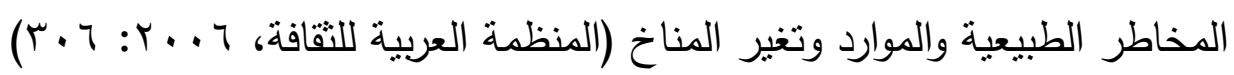

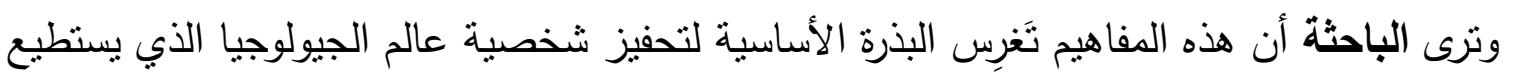
البحث في الأرض عن كل ما هو جديد ومعرفة كيفية الإستفادة منه. ويالتالي تهدف تنمية الثقافة الجيولوجية لأطفال الروضة الإلي:

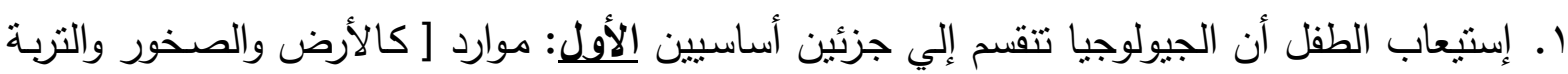

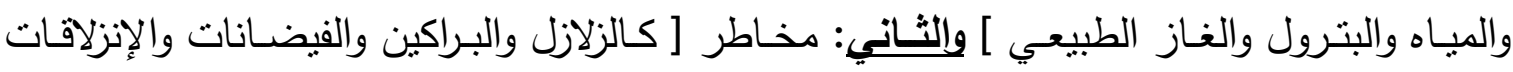

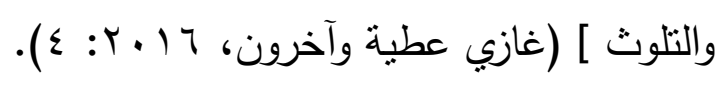

r. فهم الأطفال الصغار لخصائص الصخور والتربة ونمط التغيرات فيهما بمرور الوقت وليس الإعتماد

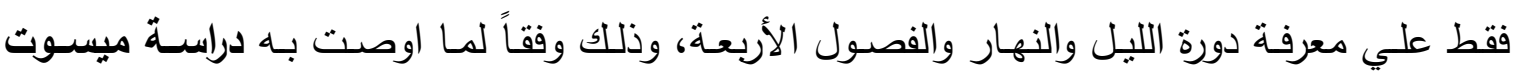

ساكس (Mesut Sackes,2015).

r. تفسير الأطفال لأسباب حدوث الظواهر الطبيعية، فلا يتكون لديهر مخاوف تجاهها بل يعرفون كيفية التعامل معها وتجنب مخاطرها (John Settlage \& Sherry, 2012:45). ع. إرتباط الطفل بالبيئة الدحيطة به وتقبله لها ومعرفة طرق الحفاظ عليها والتعامل معها بشكل سليم،. رايعاً: أبعاد الثقافة الجيولوجية لأطفال الروضة:

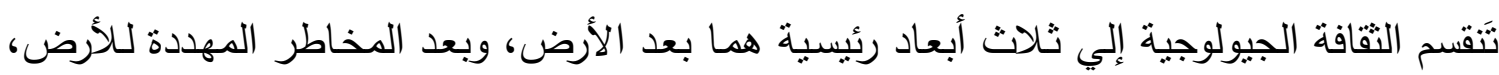

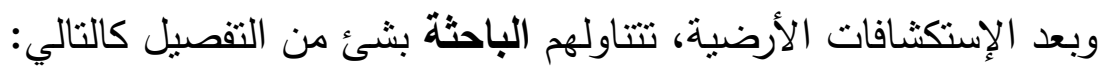

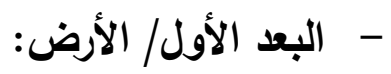

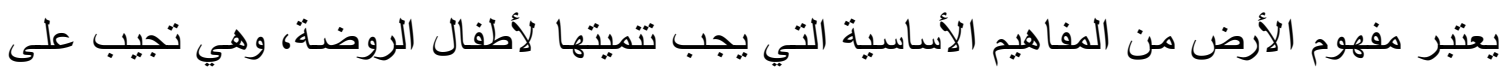

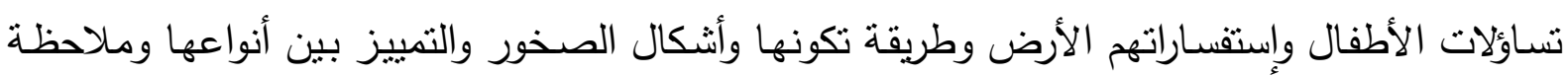

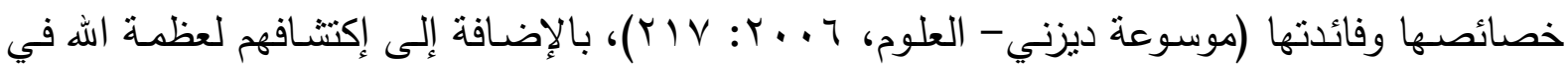


تهيئة الكرة الأرضية للحياه، وأهمية المياه والتربة لحياه الكائنات الحية وكيفية الحفاظ عليها، ويشتمل بعد الأرض على بعض المفاهيم الفرعية والأي حددتها الباحثة إجرائياً كالتالي: م مفهوم تكـوين الارض: ويُعنْي بإكتسـاب الأطفال معلومـات عن شكل الأرض الخـارجي والداخلي وأنواع طبقات الأرض وأسم كل طبقة، والتمييز بينها، وإكتشاف عظمة الله في خلق الكرة الأرضية وتهيئتها ليعيش عليها الإنسان وباقي الكائنات.

م مفهوم الصـخور : وبُعنْي بإكتسـاب الأطفال معلومـات عن أنواع الصـور وأشكالها، والتمبيز بين خصائصـها وكيفية تكونها عبر الزمن، والإهتمام بإمكانية تحويلها إلى الذهب والفضـة لتستقيد منها دول العالم. م مفهوم التربة: ويُعنْي بإكتساب الأطفال معلومات عن شكل التربة الخارجي والداخلي وطريقة تكونها عبر الزمن، والتمبيز بين خصائصها بإختلاف أنواعها، وتكوين إتجاه حول أهمية وجودها في حياه الإنسان وخطورة التعامل السيئ معها علي إختالال توازن البيئة.

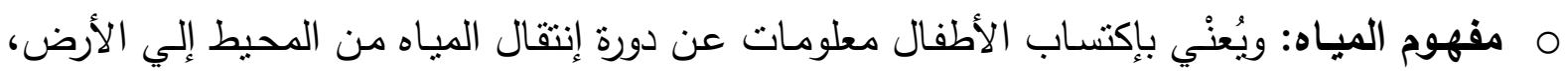
والتمييز بين أنواعها وأماكن تخزين كل منها على سطح الأرض، وتكوين إتجاه حول أهمية المياه للحياه علي الأرض وخطورة تلوثها علي الإنسان وباقي الكائنات الحية. - - البعد الثاني/ المخاطر المهددة للأرض: يستهدف مفهوم المخاطر المهددة للأرض تتمية الظواهر الطبيعية والغير طبيعيـة التي تحدث في الأرض لأطفال الروضة، حيث أنهم يحتاجون إلى تبسيط هذه الظواهر التي يشاهدونها بإستمرار سواء

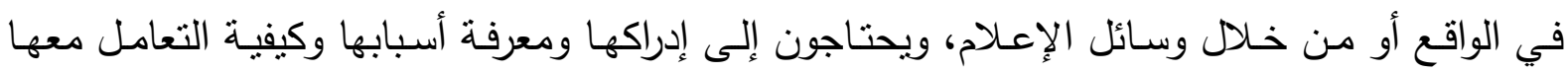
عندما تحدث، كالزلزال والبركان والفيضـان، والإهتمام بطرق الوقايـة من مخاطرهم، ومعرفة أكثر الدول إنتشاراً لها.

كما أن أطفال الروضة بحتاجون إلى معرفة كيفية التعامل مع البيئة المحيطة بهم والحفاظ عليها من كافة أثكال التلوث المختلفة التي يقوم بها الإنسان في الأرض، فيوفر تلك المفهوم المعلومات والمعارف المتعلقة بالممارسات التي يجب على الأطفال فعلها، وكيفية الإستفادة من إعادة تدوير المخلفات كإحدى

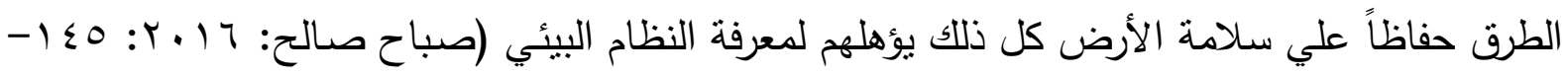
• 1 ( )، ويشتمل بعد المخـاطر المهددة لـلأرض على بعض المفـاهيم الفرعيـة والذي حددتها الباحثة إجرائياً كالتالي: م مفهوم الزلزال: ويُعنْي بإكتساب الأطفال معلومات عن المخاطر التي تهدد الأرض (الطبيعيـة والغير طبيعية)، ومعلومات عن كيفية حدوث الزلزال، وتقسير أسبابه، وأكثر الدول إنتشار لله، وتقدير دور العلماءعند حدوثه، والإهتمام بطرقة الوقاية من مخاطره وتجنب أثناره المدمرة في الأرض. 
م مفهوم البركان: ويُعنْي بإكتساب الأطفال معلومات عن شكل البركان وأنواعه والتنييز بين خصائص

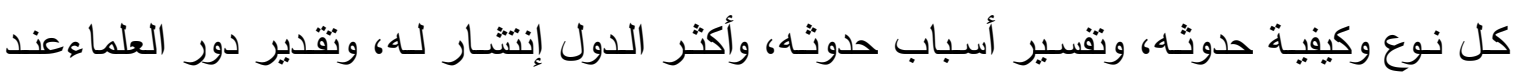

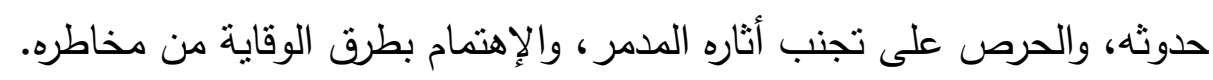

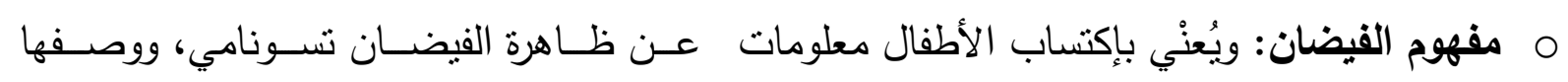

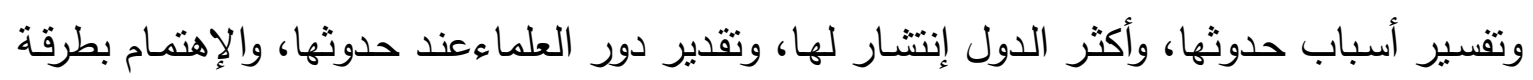

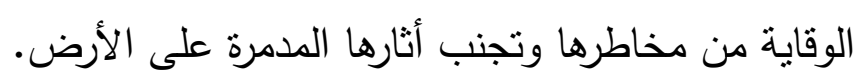

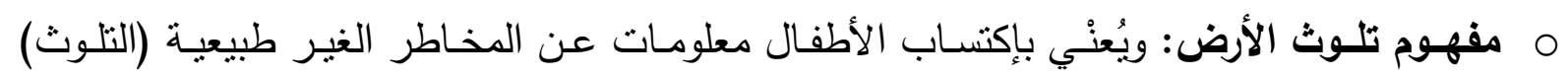

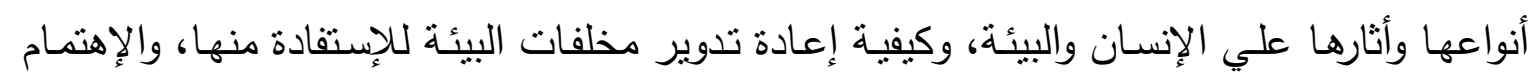
بالتخلص الآمن من نالك المخلفات حفاظاً علي سلامة كوكب الأرضان. - - البعد الثالث/ الإستكثافات الأرضية:

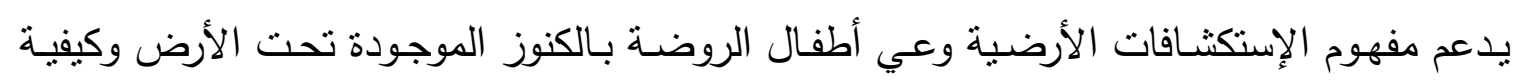

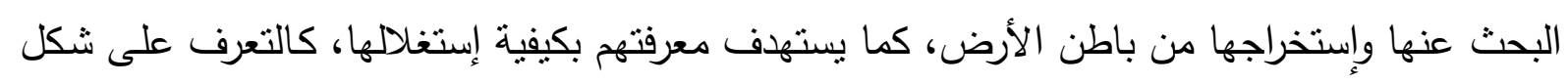

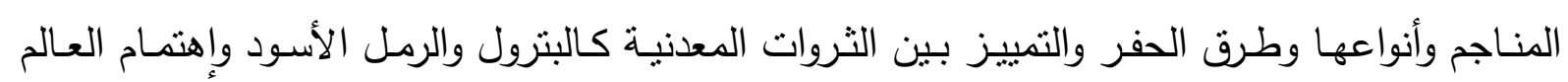

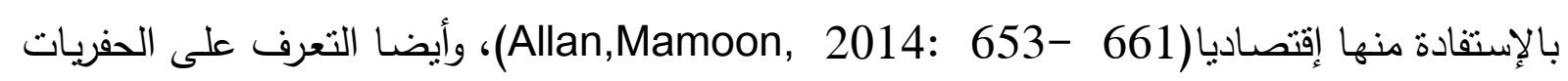

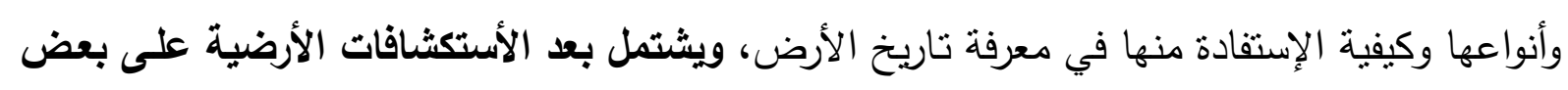
المفاهيم الفرعية والذي حددتها الباحثة إجرائياً كالتالي: الأنيا:

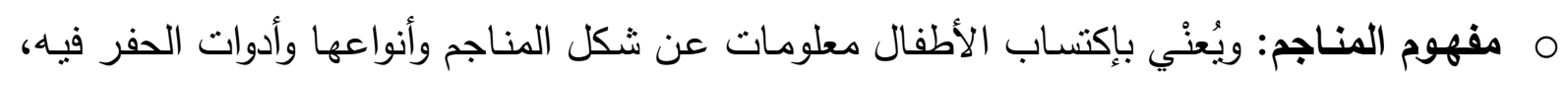

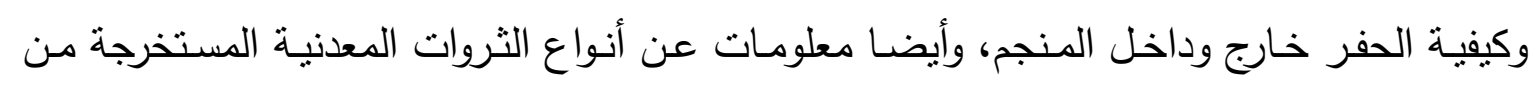

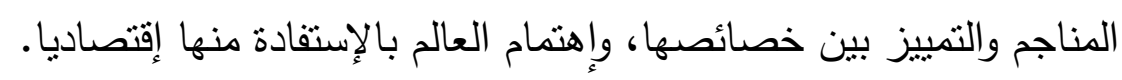

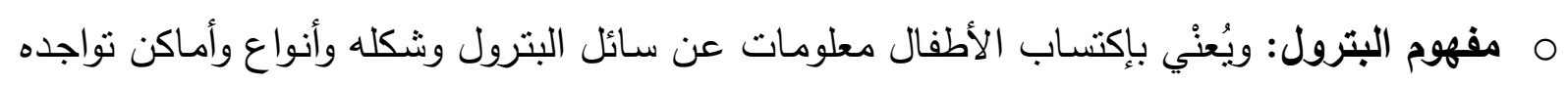

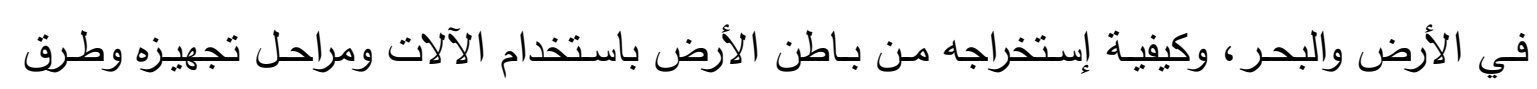
تخزينه، وتقدير دور العلماء في البحث عنه والاستفادة منه إقتصاديا كمصدر أساسي للطاقة الإنة

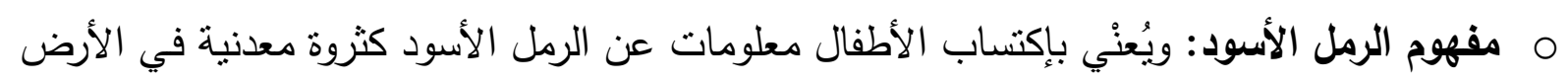

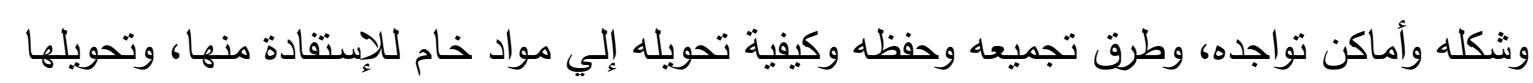

$$
\text { إلى صناعات تفيد العالم. }
$$

م مفهوم الحفريات: ويُعنْي بإكتساب الأطفال معلومات عن الكائنات الحية التي بقى آثارها منذ زمن

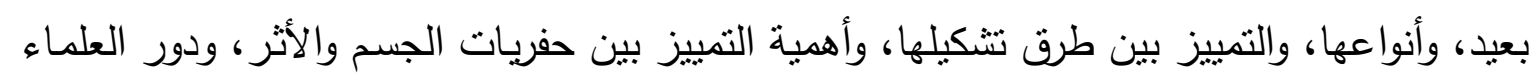

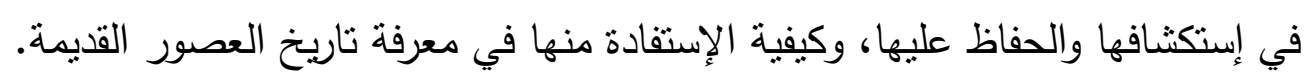


مما سبق يتضح أهمية وضرورة تتمية مفاهيم التقافة الجيولوجية للأطفال الصغار، بإسلوب علمي

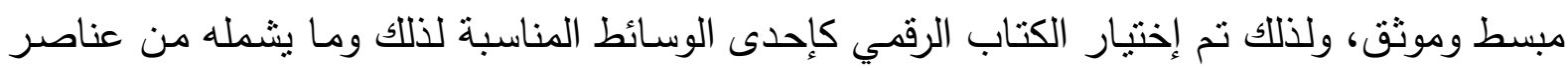
توفر التفاعل المباشر مع طفل الروضة. خطوات وإجراءات البحث: تتمتل خطوات وإجراءات البحث في الإجراءات المنهجية المتبعة فيه وتتنمل على المنهج والأدوات

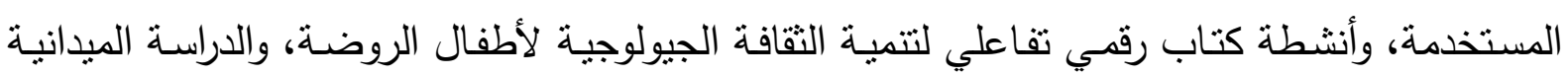
وكذلك الأساليب الإحصائية لمعالجة البيانات.

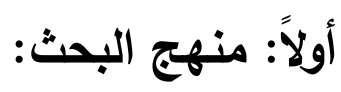
استخدم البحث الحالى المنهج شبه التجريبي Semi- Experimental Method لمناسبته لطبيعته وذلك باستخدام التصميم التجريبى ذو المجموعتين (التجريبية - الضابطة) بشرط التساوي بينهما

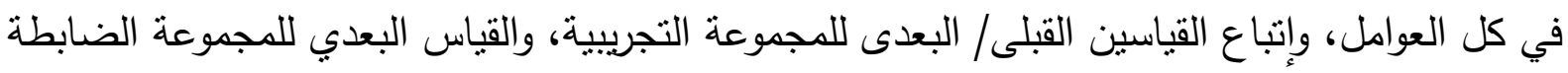

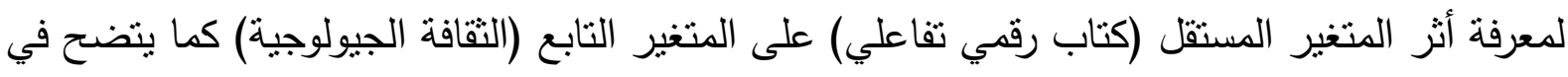

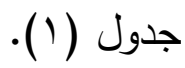

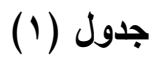

يوضح التصميم التجريبى والقياسات القبلية والبعدية لمجموعات البحث.

\begin{tabular}{|c|c|c|}
\hline المجموعة الضابطة & المجموعة التجريبية & القياسات المستخدمات الدارسة \\
\hline$x$ & $\sqrt{ }$ & القياس القبلى \\
\hline$\sqrt{ }$ & $\sqrt{ }$ & برنامج الروضة \\
\hline$\times$ & $\sqrt{ }$ & نثشطة كتاب رقمي تفاعلي \\
\hline$\sqrt{ }$ & $\sqrt{ }$ & القياس البعدى \\
\hline
\end{tabular}

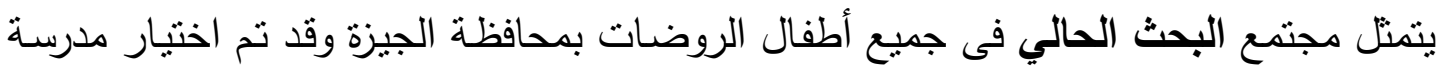

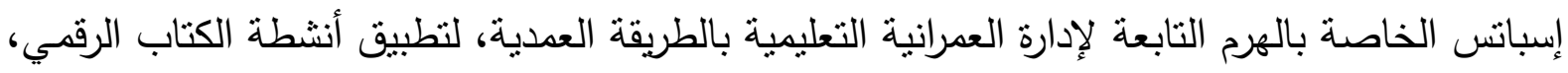
، وبلغ عدد أطفال عينة البحث (· ب) طفلاً وطفلة مقسمين إلى (10 طفلاً) للمجموعة التجريبية، و (10)

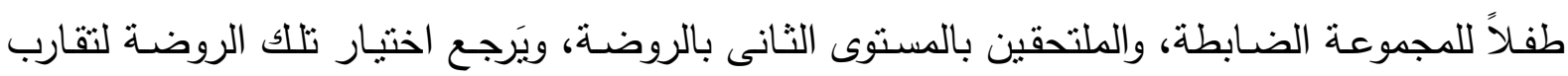

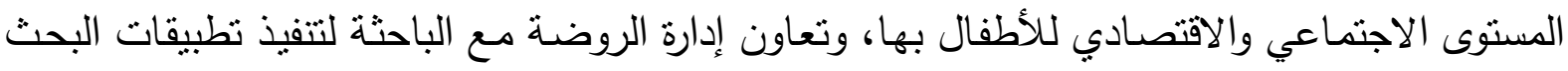

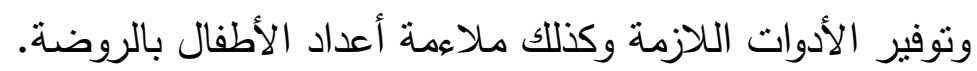


وقد راعت الباحثة عند اختيارها لعينة البحث التالي:

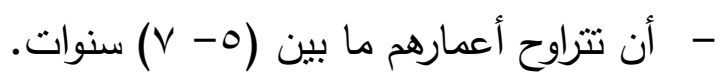

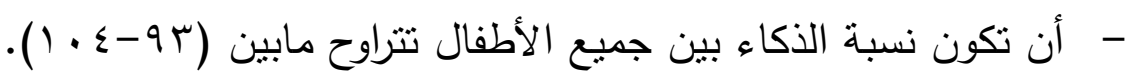

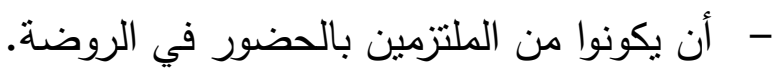

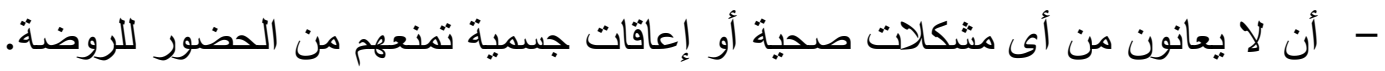
- توافر حجرة كمبيوتز بها أعداد كبيرة تتيح لكل طفل استخدام إحداها.

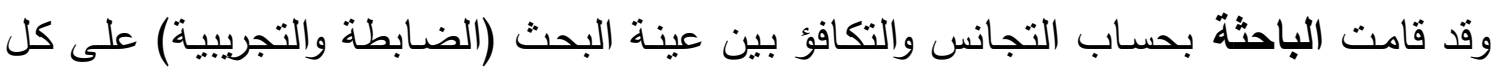

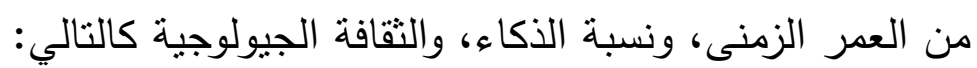
تجانس أطفال العينة

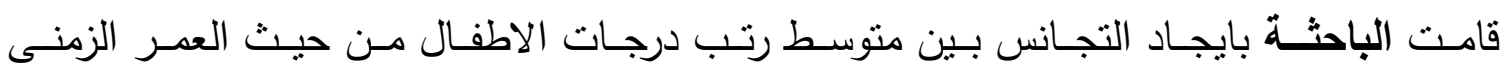

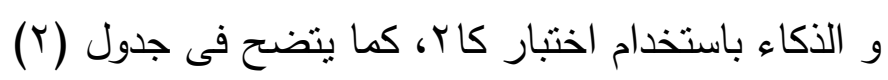

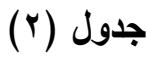
التجانس بين الاطفال من حيث العمر الزمنى و الذكاء

$$
10=0
$$

\begin{tabular}{|c|c|c|c|c|c|}
\hline \multicolumn{2}{|c|}{ حدود الدلالة } & \multirow{2}{*}{ درجة حرية } & \multirow{2}{*}{ مستوى الدلالة } & \multirow[t]{2}{*}{ كاr } & \multirow{2}{*}{ المتغيرات } \\
\hline$\ldots 0$ & $\ldots 1$ & & & & \\
\hline 9.0 & $1 \% . r$ & $\varepsilon$ & غيردالة & 8.74V & العمر الزمنى بالثهور \\
\hline 10.0 & $r \cdot . l$ & $\wedge$ & غير دالة & $r . r$ & الأكاء \\
\hline
\end{tabular}

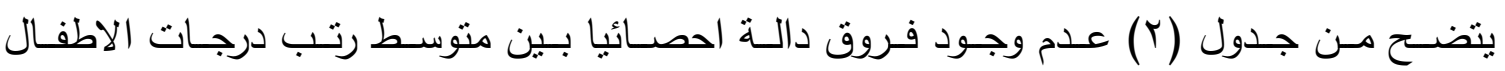

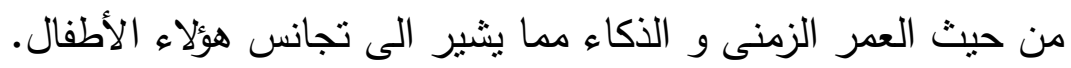

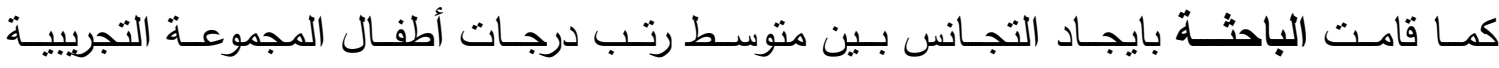

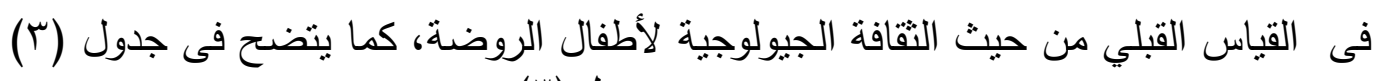

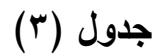

التجانس بين أطفال المجموعة التجريبية فى القياس القبلى من حيث الثقافة الجيولوجية $10=0$

\begin{tabular}{|c|c|c|c|c|c|}
\hline \multicolumn{2}{|c|}{ حدود الدلالة } & \multirow[t]{2}{*}{ درجة حرية } & \multirow[t]{2}{*}{ مستوى الدلالة || } & \multirow[t]{2}{*}{ كاr } & \multirow[t]{2}{*}{ المتغيرات } \\
\hline$\ldots 0$ & $\cdots 1$ & & & & \\
\hline 9.0 & Ir.r & $\varepsilon$ & غير دالة & $0 . \mu T$ & الارض \\
\hline V.A & $11 . r$ & $r$ & غير دالة & 0 & المخاطر \\
\hline 9.0 & Ir.r & $\varepsilon$ & غير دالة & 7 & الاستكثافات \\
\hline $1 \leqslant .1$ & 11.0 & v & غير دالة & $\varepsilon . V \mu$ & الدرجة الكلية \\
\hline
\end{tabular}


يتضـح مـن جـدول (ب) عـدم وجـود فـروق دالـة احصـائيا بــين متوسـط رتـب درجـات أطفـال

المجموعـة التجريبيـة فـى القيـاس القبلـي مـن حيـث الثقافـة الجيولوجيـة مدـا يثـير الـى تجـانس هـؤلاء الأطفال.

التكافؤ بين أطفال المجموعتين التجريبية والضابطة قامت الباحثة بايجاد دلالة الفروق بين منوسط درجات أطفال المجموعتين التجريبية والضـابطة فى

القياس القبلي من حيث العمر الزمني و الذكاء، كما يتضح فى جدول (ع) جدول (๕)

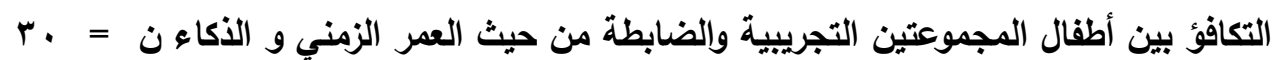

\begin{tabular}{|c|c|c|c|c|c|c|}
\hline \multirow{2}{*}{ مستوى } & \multirow[t]{2}{*}{$ت$} & \multicolumn{2}{|c|}{ المجموعة الضابطة } & \multicolumn{2}{|c|}{ المحموعة التجريبية } & \multirow[t]{2}{*}{ المتغيرات } \\
\hline & & $r \varepsilon$ & $r_{p}$ & ع & p & \\
\hline غير دالة & .rVT & $1 . Y \leq$ & 70.59 & $1 . r 9$ & $r 0 . r r$ & العمر الزمنى \\
\hline غير دالة &.$|v|$ & $r .11$ & $9 \vee .1 \%$ & r.YA & 97.94 & الأكاء \\
\hline
\end{tabular}

...

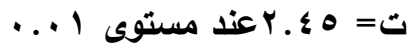

يتضــح مـن جـدول (ع) عـدم وجــود فـروق دالــة احصــائيا بـين متوســـ درجــات أطفــال

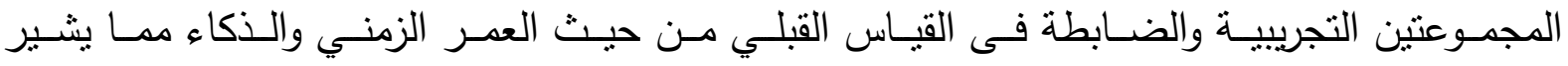
الى تكافؤ المجموعتين.

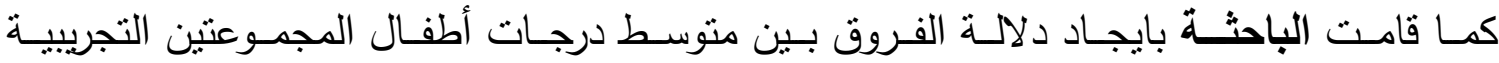

والضابطة فى القياس القبلي من حيث الثقافة الجيولوجية، كما يتضح فى جدول (0)

جدول (0)

التكافؤ بين أطفال المجموعتين التجريبية والضابطة من حيث الثقافة الجيولوجية

r. $=\dot{0}$

\begin{tabular}{|c|c|c|c|c|c|c|}
\hline \multirow{2}{*}{ مستوى } & \multirow[t]{2}{*}{$ت$} & \multicolumn{2}{|c|}{ المجموعة الضابطة } & \multicolumn{2}{|c|}{ 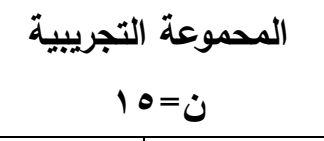 } & \multirow[t]{2}{*}{ المتغيرات } \\
\hline & & $r \varepsilon$ & $r_{p}$ & ' & م & \\
\hline غير دالة & .rq & $1.1 \mathrm{~V}$ & Tr.rr & I.rr & Ir.r & الارض \\
\hline غير دالة & .109 & 1.50 & ir & $1 . . r$ & Ir.qr & المخاطر \\
\hline غير دالة & $.91 \leqslant$ &. .97 & IT.VT & $1 . r \varepsilon$ & $1 \mathrm{~T} .1 \mathrm{r}$ & الاستكشافات \\
\hline غير دالة & .YYI & $r .7 r$ & $r q . .9$ & Y.MI & Mq.Y & الدرجة الكلية \\
\hline
\end{tabular}


يتضـح مـن جـدول (0) عـدم وجـود فـروق دالــة احصــائيا بـين متوســـ درجـات أطفـال

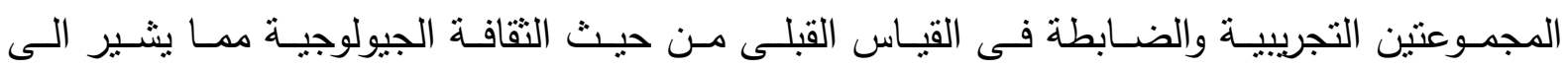
تكافؤ المجموعتين.

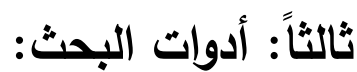
قامت الباحثة باستخدام الأدوات التالية:

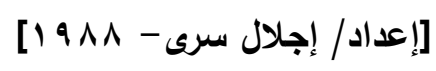

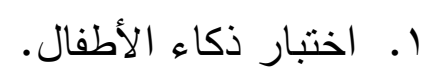

r. استمارة إستطلاع الرأي لتحديد مفاهيم الثقافة الجيولوجية المناسبة لأطفال الروضة. [إعداد/ الباحثة] [إعداد/ الباحثة] r. مقياس رقمي تفاعلي الثقافة الجيولوجية لاطفال الروضة. [إعداد/ الباحثة]

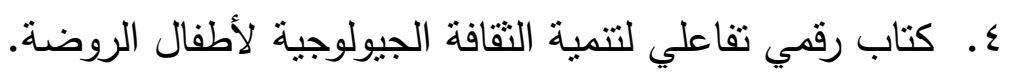

[إعداد/ إجلال سري] وفيما يلي وصف تفصيلي لهذه الأدوات: قامت الباحثة باستخدام هذا الاختبار لحساب مؤشر الذكاء للأطفال.

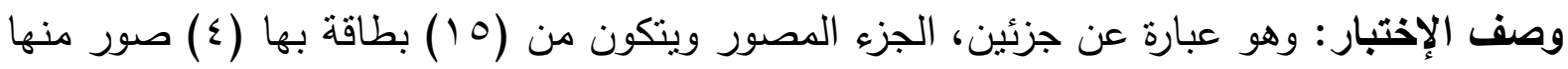

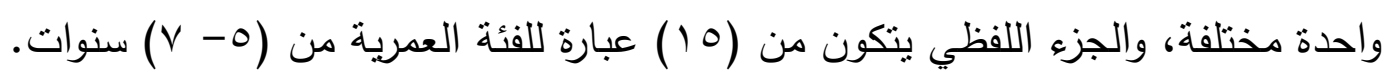
المعاملات الإحصائية لمقياس إجلال سرى للأكاء تم حساب صدق وثبات المقياس كالتالي: أ- صدق المقياس: استخدمت (إجلال سرى) صدق المحك باستخدام اختبار (ستانفور وبينيه) للذكاء

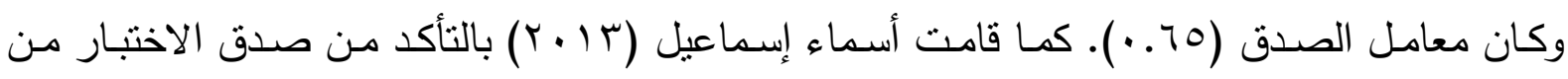

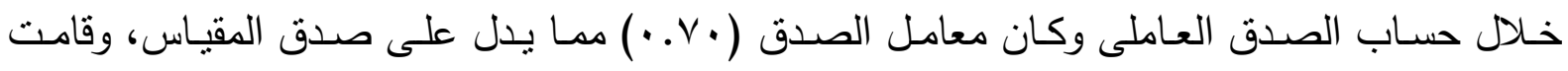

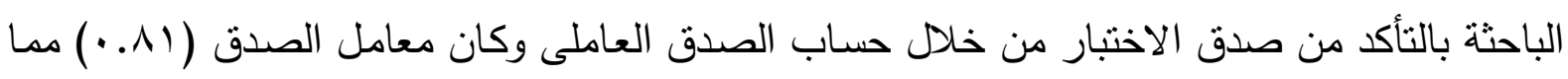

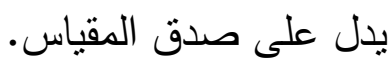
ب- ثبات الاختبار : استخدمت (إجلال سرى) طريقة إعادة الاختبار لتحديد معامل ثباته، حيث تم تطبيقه

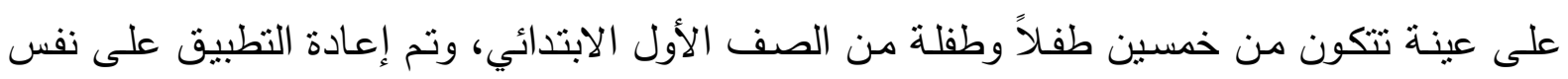

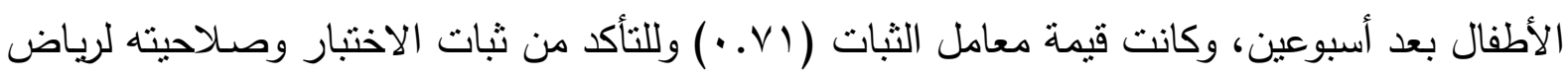

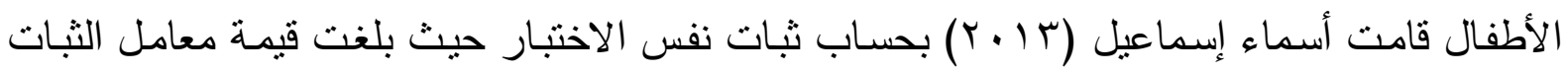

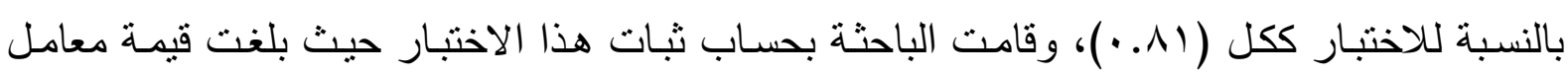

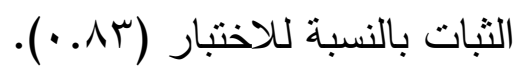




\section{r - استمارة إستطلاع الرأي لتحديد مفاهيم الثقافة الجيولوحية المناسبة لأطفال الروضة.}

[إعداد/ الباحثةة]

قامت الباحثة بإعداد قائمـة "بمفاهيم الثقافة الجيولوجية" وقد تم تحديدها بعد الاضطلاع على العديد مـن المراجـع والخلفيـات النظريـة والإستبيانات مثنل إستبيان تكنولوجيـا الفضـاء وعلـوم الأرض بمناهج التعليم في مصر إعداد/ عايدة عباس (Y V P r)، وتم إعداد الاستمارة فى صورتها النهائية، وتم عرضـها على السـادة الخبراء المحكمين، وقد تم تعديل الاستمارة فى ضوء آرائهح وقد اعتبرت الباحثة "مفاهيم الثقافة الجيولوجية" المناسبة إذا ما حصلت على (،^\%) فأكثر من الآراء واتفق السادة الخبراء على (r) ثلاث أبعاد رئيسية للثقافة الجيولوجية الأكثر مناسبة لطفل الروضـة وهما: (الأرض - المخاطر المهددة للأرض - الاستكثافات الأرضية)، وتم تحديد أيضا (r ( ) أثني عشر مفهوم فرعي الأكثر مناسبة لطفل الروضـة وهما [ الأرض/ تكوين الأرض - الصـور - التربـة - دورة المياه] -[المخـاطر المهددة للأرض/ الزلزال - البركان - الفيضان - تلوث الأرض] - [الاستكثافات الأرضية/ المناجم - البترول -

$$
\text { الرمل الأسود - الحفريات] }
$$

\section{r- مقياس رقمي تفاعلي الثقافة الجيولوحية لاطفال الروضة.}

[اعداد/ الباحثة]

الهرف من المقياس الرقمي:

يهدف تصميم المقياس إلي قياس مدى اكتساب أطفال الروضـة لمفاهيم التقافة الجيولوجية ومدى فاعلية الكتاب الرقمي التفاعلي في ذلك، ويتم القياس عن طريق عرض الباحثة لأسئلة المقياس المصور رقمياً علي الثـاشـة، ويقوم الطفل بسماع كل سؤال بمفرده أو بمسـاعدة الباحثة في توضيح العبـارات المصاحبة لكل سؤال ليختار البديل المصور الصحيح بالضغط على الصورة، ثم ينتقل رقمياً إلى السؤال التالي سواء كانت إجابته صحيحة أم خاطئة، ويقوم المقياس بحسـاب درجات الطفل بشكل رقمي عند إنتهاؤه من جميع المفردات، ويتكون المقياس من (بr سؤال) مقسمين على الأبعاد التالية:

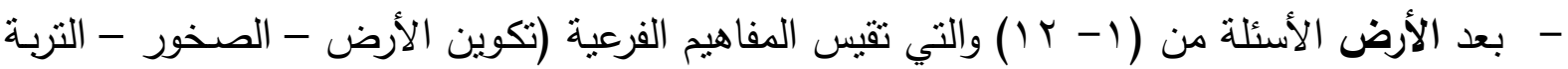
- دورة المياه) - بعد المخاطر المهددة للأرض الأسئلة من (T ا - ؟Y) والتي تقيس المفاهيم الفرعية (الزلزال - البركان - الفيضان - تلوث الأرض)

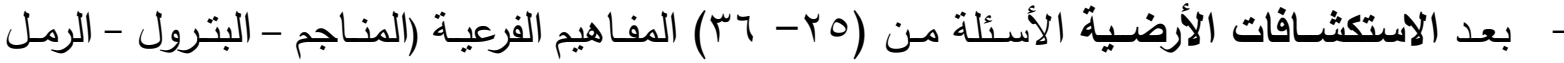

$$
\text { الأسود - الحفريات) }
$$

بحيث يقيس كل مفهوم من المفاهيم الفرعية الجانب المعرفي في السؤال الأول والجانب المهاري في السؤال الثاني والجانب الوجداني في السؤال الثالث لمقياس الثقافة الجيولوجية لدى طفل الروضة. 
خطوات تصميم المقياس الرقمي: ( ) الإطلاع على البحوث والدراسـات السـابقة ذات الصـلة بموضوع البحث للاستفادة منها فى إعداد المقياس الحالي.

r) التدريب على برنامج "Director" وذللك لتصميم وحدات المقياس بشكل رقمي. r) تم وضع التعريف الإجرائي للافقافة الجيولوجية في ضوء الاطلاع على الإطـار النظري والدراسـات

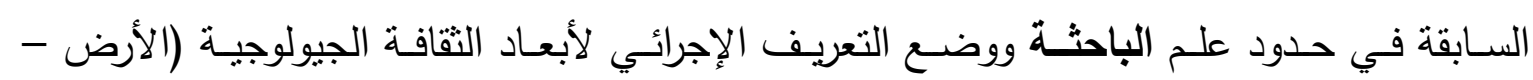
المخاطر - الإستكثافات) وتحديد المفاهيم المرتبطة بها وكيفية قياسها إجرائياً. ع) قامت الباحثة بالإطلاع على عدد من المقاييس التي ساهمت بدورها في إعداد المقياس الرقمي للنقافة

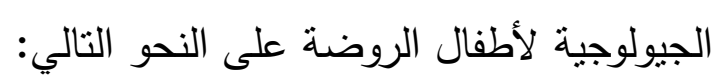

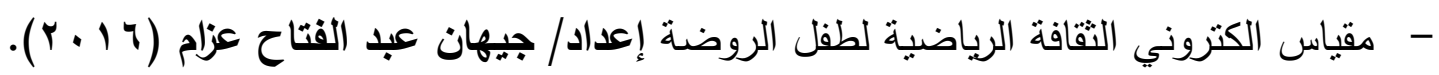

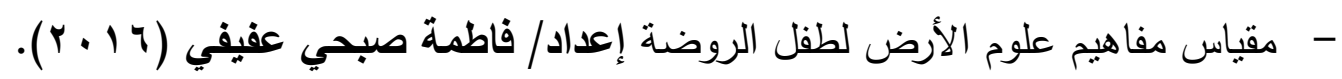

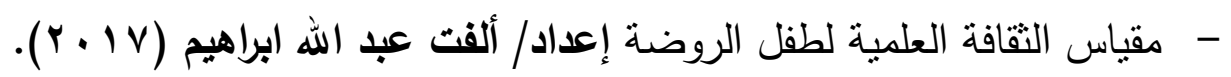
وقد استفادت الباحثة من هذه المقاييس عند إعداد مقياس البحث الحالي في التعرف على مفاهيم

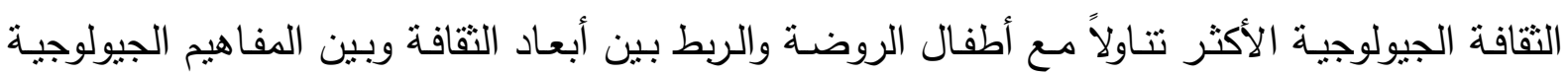

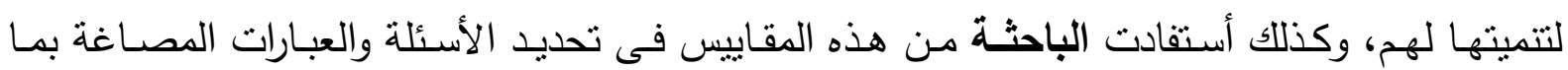
يتتاسب مع عمر الأطفال حيث يحتاجوا إلى أن تكون مصورة وبها حركة ومن هنا جاءت أهمية اعداد المقياس رقمي تفاعلي ليتتاسب مع أطفال الروضة.

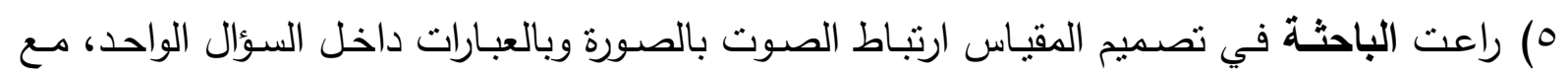

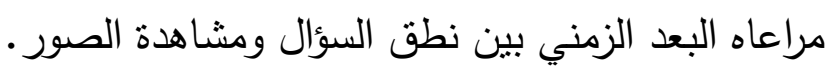

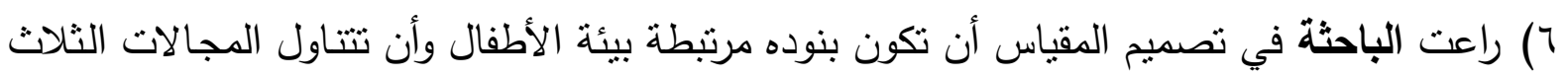
(المعرفية، المهارية، الوجدانية).

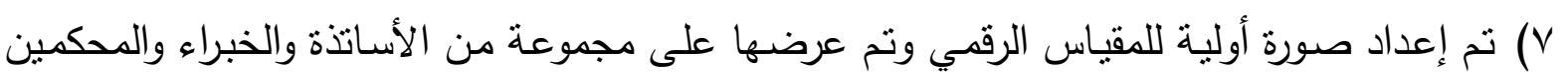

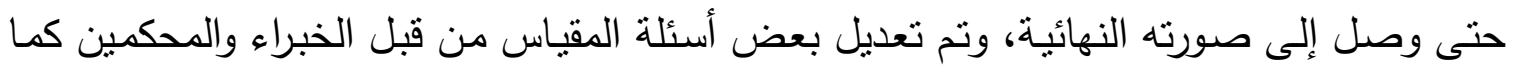
يتضح في جدول (T): 


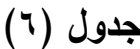

تعديل بعض أسئلة مقياس الثقافة الجيولوجية وفقاً لآراء المحكمين

\begin{tabular}{|c|c|c|}
\hline السؤال بعد التعديل & السؤال قبل التعديل & | السؤال \\
\hline إلي : وضع كلمة هي ..... في نهاية السؤال & إستبدال أداه الإستقهام (ما) في جميع الأسئلة & \\
\hline 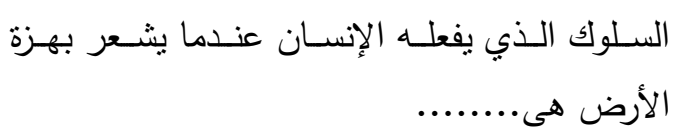 & هـ........... الفعل الذي تقوم بـه عندما تثـعر بهزة الأرض & 10 \\
\hline إلي: ينفجر في أي لحظة & تغيير البديل الدصور من : يمكن أن ينفجر & iv \\
\hline 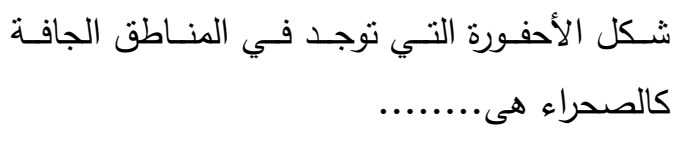 & الأحفورة التي تتكلت في الدنـاطق الصـحراوية & $\mu \varepsilon$ \\
\hline
\end{tabular}

وتراوحت نسبة اتفاق الأساتذة المحكين على أبعاد المقياس ككل ما بين (•^م - . . 1\%) كما

(v) بنضح في جدول

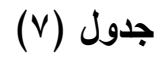

يوضح النسبة المئوية لاتفاق آراء المحكمين على أبعاد مقياس الثقافة الجيولوجية لأطفال الروضة

\begin{tabular}{|c|c|c|}
\hline النسبة المئوية & الأبعاد & p \\
\hline$\% 1 \ldots$ & الأرض & 1 \\
\hline$\% \wedge$. & المخاطر المهددة للأرض & r \\
\hline$\% 1 \ldots$ & الإستكثافات الأرضية & $r$ \\
\hline
\end{tabular}

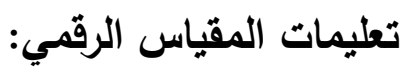

- - يقوم الطفل بسماع السؤال سواء بمفرده أو بمساعدة الباحثة، ومشـاهدة البدائل ثم إختيار الإجابـة المناسبة.

- - تؤكد الباحثة على الطفل ان يستمع للسؤال جيدا حتى يتمكن من حله.

- تتبه الباحثة على الطفل ان يضغط مرتين على زر الفأرة الأيسر عند اختيار الاجابة المناسبة.

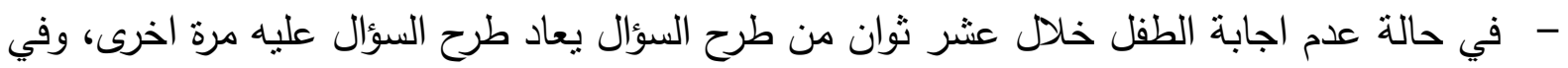
حالة عدم الاجابة ينتقل للسؤال الذي يليه ويعتبر الاجابة خطأ. زمن تطبيق المقياس الرقمي: قامت الباحثة بتحديد (·r دقيقة) لكل طفل، وذلك كمنوسط للزمن الذى استغرقه الأطفال في التجربة الاستطلاعية. 


\section{طريقة تصحيح المقياس الرقيم:}

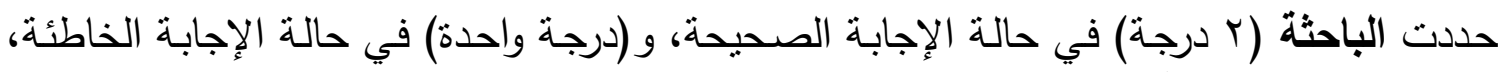

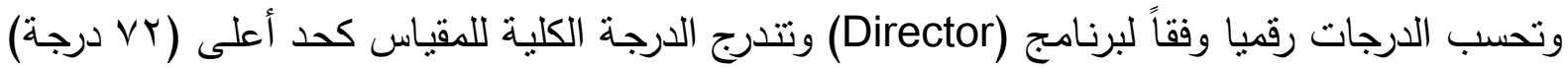
وكحد أدني (ب آب درجة).

الخصائص السيكومترية لمقياس رقمي الثقافة الجيولوجية لأطفال الروضة

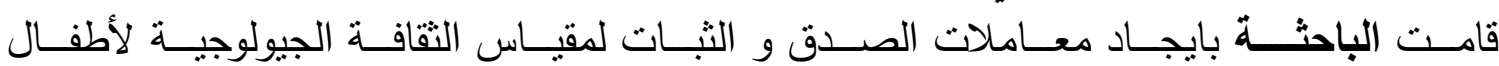

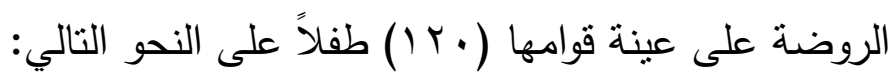

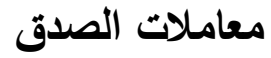

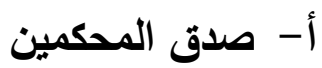

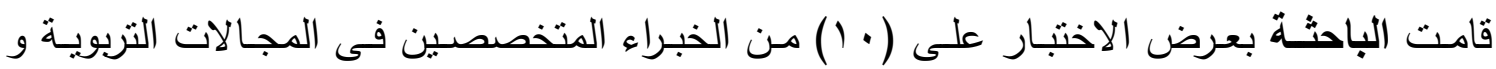

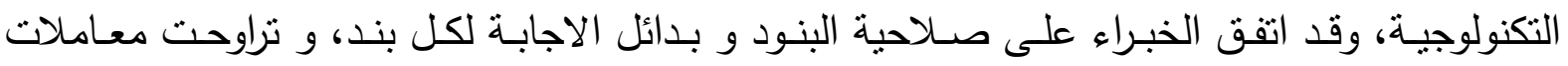

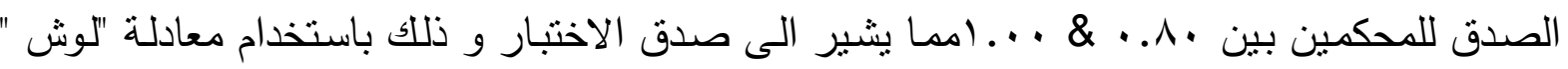
.Lawshe ب-الصدق العاملي

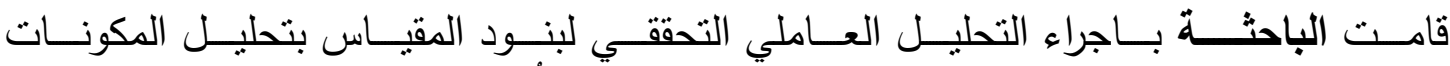

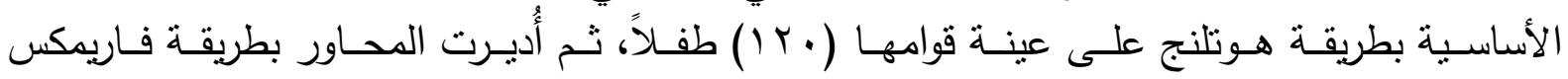

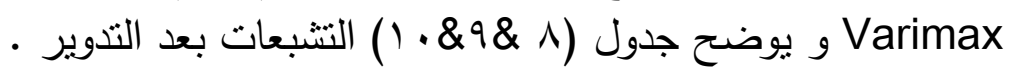

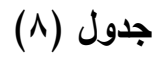

التثبعات الخاصة بالعامل الأول (الارض) (ب)

\begin{tabular}{|c|c|c|}
\hline التشبعات & 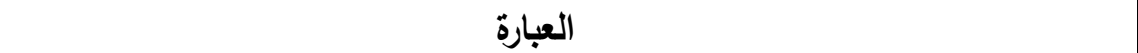 & رقم العبارة \\
\hline..$\wedge \wedge$ & مكونات الأرض هى........ & 1 \\
\hline.$\wedge 0$ & أول طبقة للأرض التي نعيش عليها وبتكون رقيقة جدا هى........ & r \\
\hline.$\Delta r$ & الكائنات الحية التي خلقها ربنا ليستقبد منها الإنسان علي الأرض هى........ & $r$ \\
\hline$\because \vee 9$ & |الصخرة التي تحتاج إلى حرارة شديدة هى................ & $\varepsilon$ \\
\hline.$\vee 17$ & أول مرحلة في تكوين صخرة النار هى....... & $\bullet$ \\
\hline.$V r$ & الثئ الذي تتحول له الصخور ويستقيد منه الإنسان هو ....... & 9 \\
\hline .79 & طبقة التربة التي تتكون من قطع صخور صغيرة هى........ & $\mathrm{v}$ \\
\hline$. .7 \leqslant$ & نوع التربة الصالحة لزراعة النباتات ويوجد به بقايا الكائنات الحية هى....... & $\Lambda$ \\
\hline .00 & أهمية حفاظ الإنسان علي التربة هى............... & 9 \\
\hline $.0 \leqslant$ & الثئ الذي يحتوبي على المياه العذبة الصالحة للشرب و وينزل على الأنهار هو ........ & 1. \\
\hline $.0 \mathrm{r}$ & سبب ظهور بخار المياه في الهواء هو ........ & 11 \\
\hline$\cdot . \leqslant 9$ & الأشياء التي تدخل في صناعنها المياه ويستقيد منها الإنسان هى................. & ir \\
\hline $0 . \wedge 0$ & 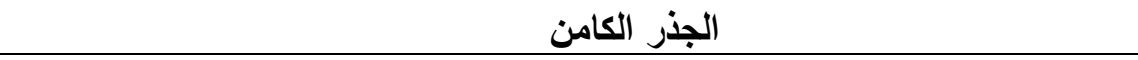 & \\
\hline$\% 1 \vee .97$ & نسبة التباين & \\
\hline
\end{tabular}

يتضح من جدول (^) أن جميع التشبعات دالة إحصائياً حيث ان قيمة كل منها أكبر من • بـ. على محك جيلفورد. 
جدول (9) جان (9)

التشبعات الخاصة بالعامل الثاني (المخاطر المهدةة للأرض)

\begin{tabular}{|c|c|c|}
\hline التشبعات - ل التشات & العبارة & رقم العبارة \\
\hline. .11 & أفضل وصف للززلزال هو ........ & ir \\
\hline$\cdot . \wedge$. & سبب حدوث الززال الثديد في الأرض هو ....... & $1 \varepsilon$ \\
\hline..$\vee 9$ & السلوك الذي يفعله الإنسان عندما يشعر بهزة الأرض هى...... & 10 \\
\hline..$V r$ & الصى.......... الصغي تخرج من فتحة البركان بعنف أثناء الإنفجار الثديد وتتحول إلى سائل نار. & 17 \\
\hline.$\cdot v$. & الذي يميز البركان الخامد هو ........ & iv \\
\hline. .79 & إنفجار بركان هو ........... الإنسان عندما يشاهد رماد في الجو نتيجة حريق الغابات الناتج من & 11 \\
\hline. .71 & أفضل وصف للفيضان تسونامي هو ........ & 19 \\
\hline$. .0 \leqslant$ & سبب حدوث الفيضان هو ......... & r. \\
\hline. .01 & نتيجة حدوث الفيضان في البحر هى........ & r \\
\hline...$\leqslant$ & الآثار الخطيرة للتوث الأرض هى....... & rr \\
\hline..$\leqslant r$ & الثئ الذي نعيد تدويره إلي علب كارتون هو ........ & rr \\
\hline..$r 9$ & السلوك الذي يفعله الإنسان ليحافظ على البيئة من زيادة القمامة هو ........ & $r \varepsilon$ \\
\hline \&.^o & الجذر الكامن & \\
\hline$\% 1$ \%. & نسبة التباين & \\
\hline
\end{tabular}

يتضـح مـن جـول (9) أن جميـع التشـبعات دالــة إحصـائياً حيـث ان قيمـة كـل منهـا أكبـر مـن

r. ا. . على محك جيلفورد. 


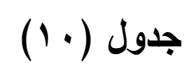

التشبعات الخاصة بالعامل الثالث (الإستكثافات الأرضية)

\begin{tabular}{|c|c|c|}
\hline التشبعات & 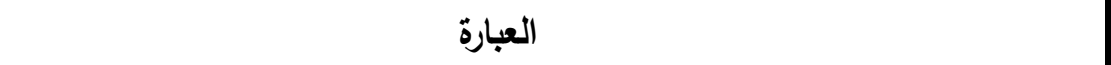 & رقم العبارة \\
\hline..$v 1$ & |. شكل المنجم هو .... & ro \\
\hline ..v. & الطريقة التي يستخدمها العلماء للحفر داخل المناجم هى....... & rq \\
\hline .v. & الإستفادة من استخراج الذهب والفضة والأحجار الكريمة من المناجم هى....... & YV \\
\hline זות & الآلة التي يستخدمها الإنسان في البحث عن سائل البترول تحت الأرض هى........ & r \\
\hline ..0. & المرحلة الأخيرة لإستخراج البترول واستخدامه هى................. & rq \\
\hline..$\$ 9$ & الأشياء التي تدخل في صناعتها سائل البترول بشكل أساسي هى............. & r. \\
\hline .. $\leqslant 0$ & مكان تواجد الرمل الأسود في الأرض هو ........ & r \\
\hline . & المواد التي يتم تحويل الرمل الأسود لها هى......... & rr \\
\hline . .49 & الصناعات التي تتنجها الدول باستخدام الرمل الأسود هى........ & r \\
\hline .r & شكل الأحفورة التي توجد في المناطق الجافة كالصحراء هى................ & ع \\
\hline ה & الثنئ الذي يميز الأحفورة الأثرية للايناصور هو ............. & ro \\
\hline .r. & السلوك الذي يفعله العلماء عند وجود أحفورة قديمة هو ............. & m \\
\hline r.r. & الجذر الكامن & \\
\hline$\% \wedge . \leqslant 0$ & نسبة التباين & \\
\hline
\end{tabular}

يتضح من جدول (· () أن جميع التتبعات دالة إحصائياً حيث ان قيمة كل منها أكبر من • r.. على محك جيلفورد. معاملات الثبات

قامت الباحثّة بإيجاد معاملات الثبات لدقياس الثقافة الجيولوجيـة لأطفال الروضـة بطريقتى الفا

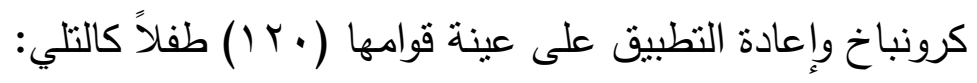
أ- طريقة الفا - كرونباخ

قامت الباحثة بإيجاد معاملات الثبات لمقياس الثقافة الجيولوجية لأطفال الروضة باستخدام معامل

الفا - كرونباخ كما يتضح فى جدول (1) 
جدول (II)

معاملات الثبات لمقياس الثقافة الجيولوجية لأطفال الروضة باستخام معامل الفا - كرونباخ

\begin{tabular}{|c|c|}
\hline معاملات الثبات & الابعاد \\
\hline.$\wedge \varepsilon$ & الارض \\
\hline. .14 & المخاطر \\
\hline. .11 & الاستكشافات \\
\hline.$\Delta r$ & الارجة الكلية \\
\hline
\end{tabular}

يتضح من جدول (1) (1) ان قيم معاملات الثبات مرتفعة مما يدل على ثبات الاختبار

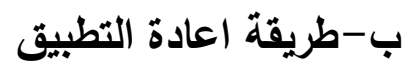

قامت الباحثة بإيجاد معاملات الثبات باستخدام طريقة إعادة التطبيق بفاصل زمنى أسبوعين كما

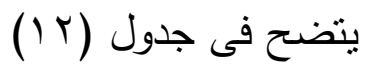

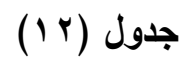

معاملات الثبات لمقياس الثقافة الجيولوجية لأطفال الروضة باستخلام طريقة اعادة التطبيق

\begin{tabular}{|c|c|}
\hline معاملات الثبات & الابعاد \\
\hline. .91 & الارض \\
\hline .91 & المخاطر \\
\hline . .94 & الاستكثافات \\
\hline . .9r & الارجة الكلية \\
\hline
\end{tabular}

يتضح من جدول (r ( ) ان قيم معاملات الثبات مرتقعة مما يدل على ثبات الاختبار

وفيما يلى عرض لبعض أسئلة مقياس الثقافة الجيولوجية لطفل الروضة 


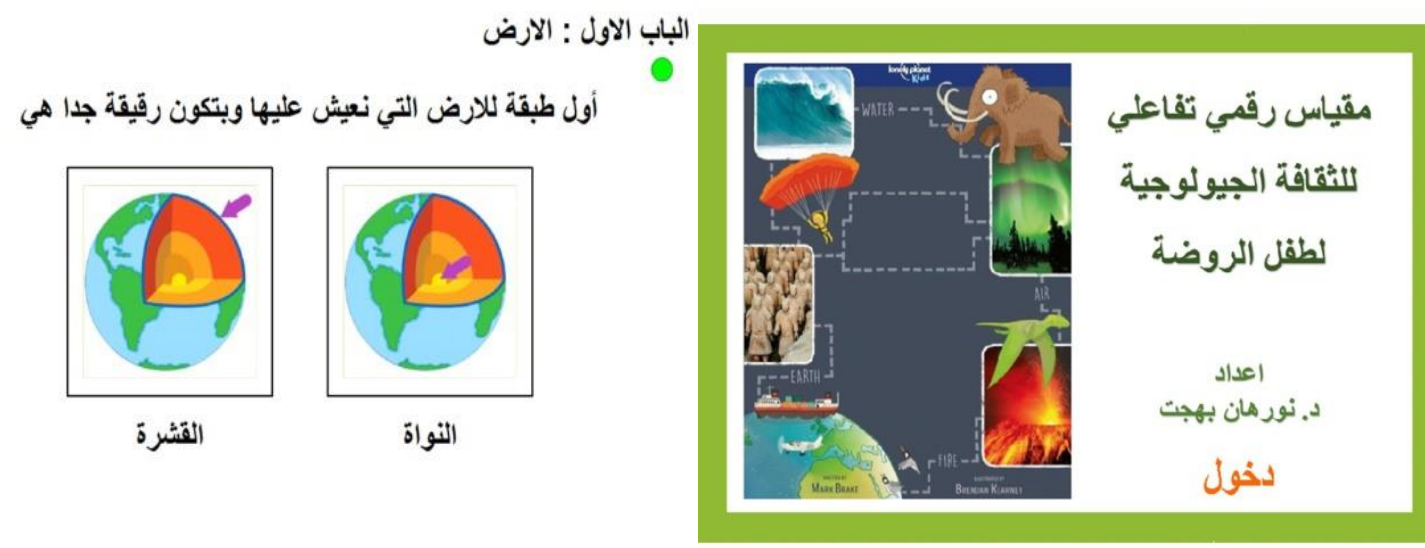

الباب الاول : الارض

الثيء الذي تتحول اليه الصخور ويستفاد منه الانسان

الباب الاول : الارض

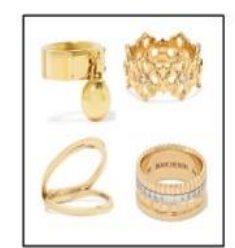

الذهب

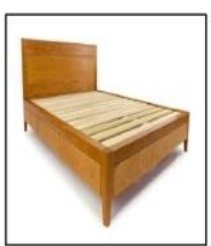

الخثب

ب

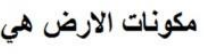

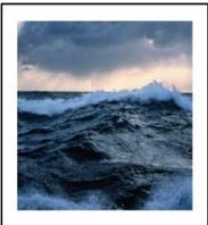

مياة فقط

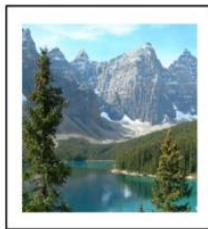

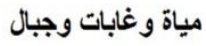

\section{ع - كتاب رقمي تفاعلي لتنمية الثقافة الجيولوحية لأطفال الروضة.}

[إعداد/ الباحثة]

الهذف من الكتاب الرقمي التفاعلي

قامت الباحثة بإعداد كتاب رقمي تفاعلي لتتمية الثقافة الجيولوجية لأطفال الروضة، بحيث ينقسم

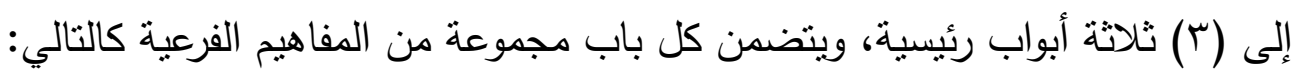

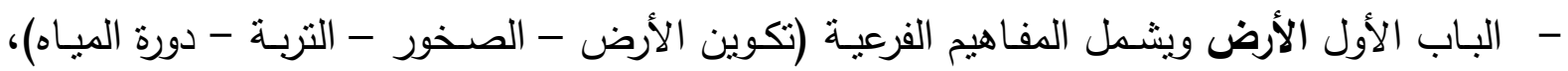

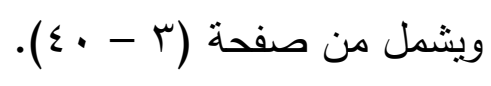

- الباب الثاني المخاطر المهددة لـلأرض ويشمل المفاهيم الفرعية (الزلزال - البركان - الفيضـان -

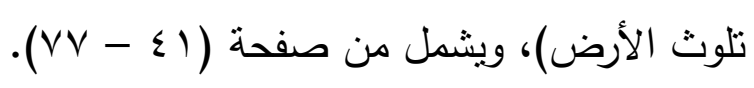

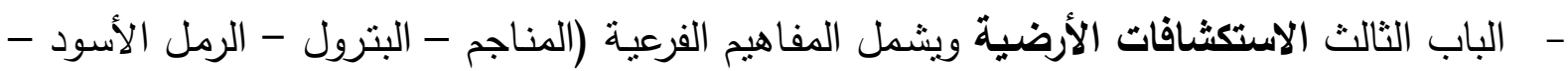

$$
\text { الحفريات)، ويشمل من صفحة (لv - - (1). }
$$




\section{وصف مكونات الكتاب الرقمي التفاعلي}

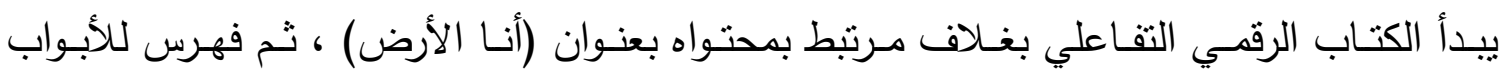

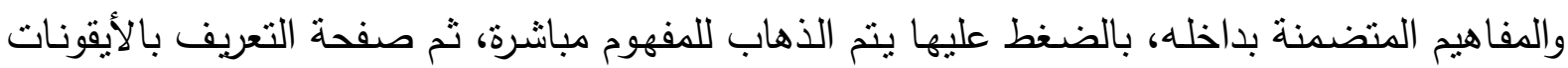
المستخدمة في الكتاب ومعناها، ويتم عرض صفحات الكتاب بالتتابع بالضغط على زر الإنتقال، وتحتوي كل صفحة علي المعلومات أو الحقائق أو التطبيقات التفاعلية على شكل صوض صور ورسوم متحركة وفيديو

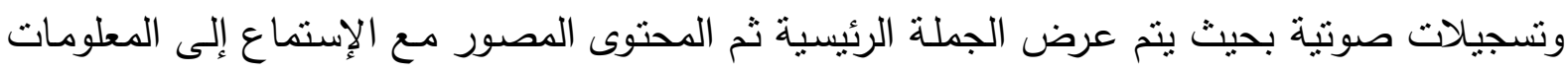

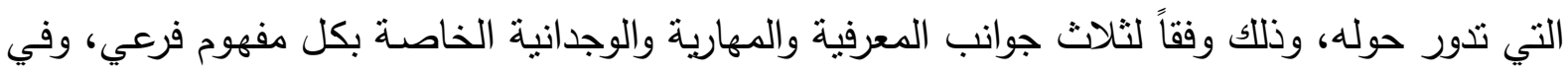
نهاية الكتاب قاموس لغوي مصور لكل الكلمات المرتبطة بالجيولوجيا والتي وردت في الكتاب الرقمي.

وفيما يلى عرض لبعض صفحات الكتاب الرقمي لتنمية الثقافة الجيولوجية لاطفال الروضة

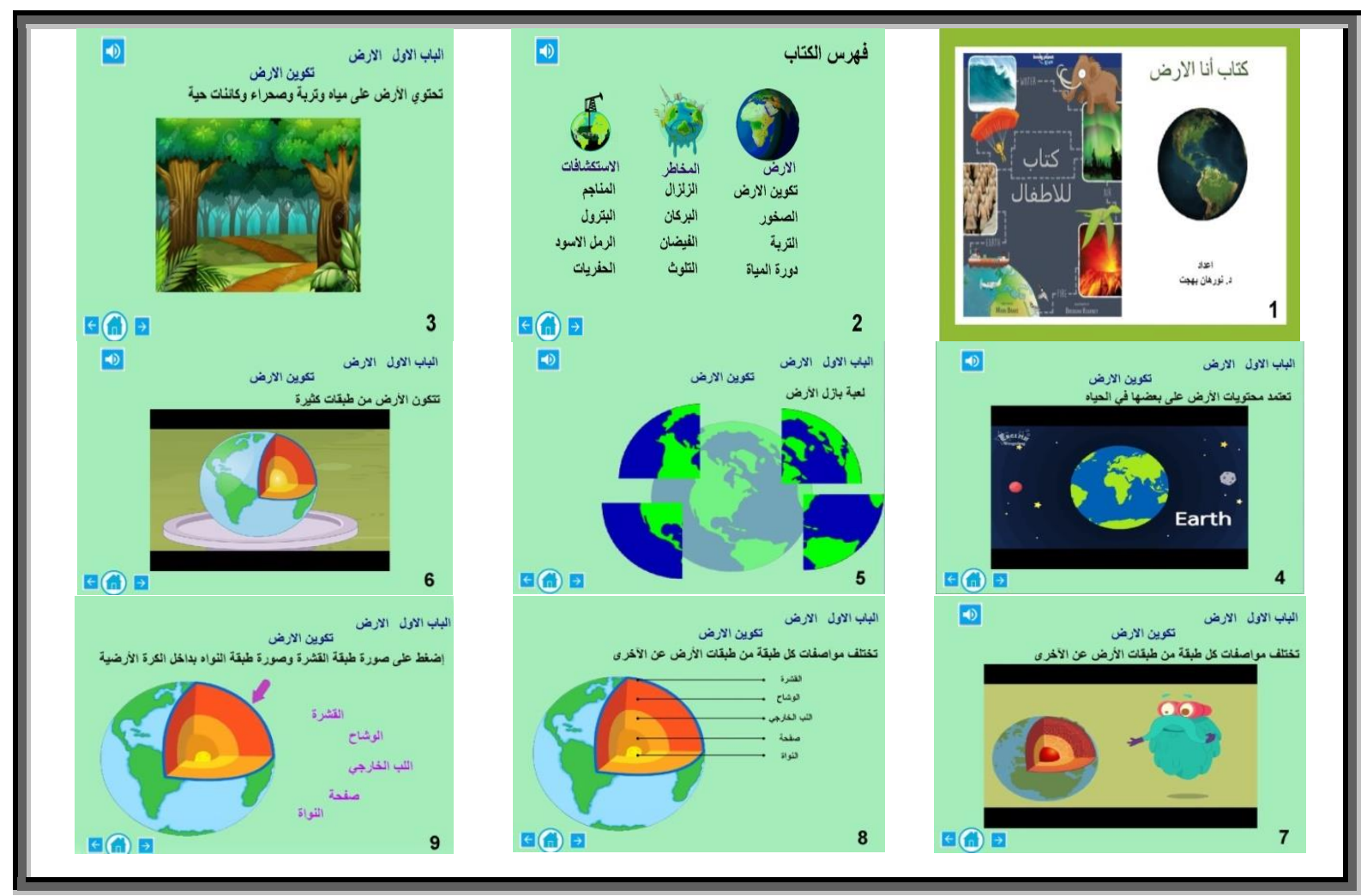

أسس إعداد الكتاب الرقمي التفاعلي

إعتدت الباحثة في إعداد الكتاب الرقمي التفاعلي لأطفال الروضة على لعى علي الأسس التالية:

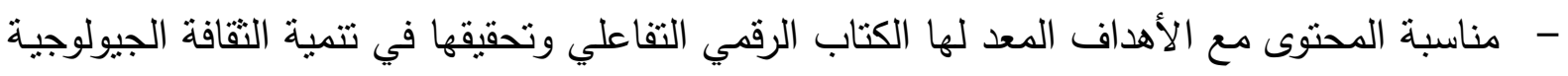
لأطفال الروضة.

- - مناسبة الكتاب الرقمي التفاعلي مـع خصـائص الأطفال في مرحلـة الروضــة من حيث التصـيم والمحتوى. - - إعتماد محتوى الكتاب الرقمي التفاعلي على التعلم الذاتي للأطفال. 
- - عدم الحاجة لمعرفة مسبقة بالحاسب الآلي لكي يستخدم الطفل الكتاب الرقمي.

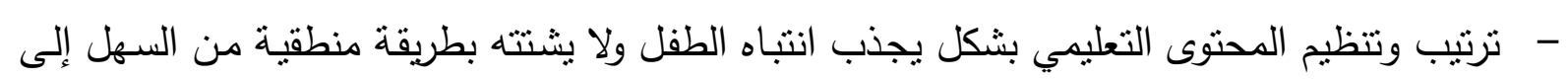
الصعب.

- - سهولة ووضوح تعليمات وإرشادات استخدام الكتاب الرقمي لأطفال الروضة. - تصميم الغلاف والفهرس بشكل مناسب للموضوع وخصائص الأطفال. - - إمكانية تكرار المعلومة أكثر من مرة حسب احتياج الطفل وسرعته في التعلم لضمان الضمان التعلم. - التوظيف المناسب لمختلف عناصر الوسائط المتعددة دون ازدحام صفحة الكتاب الرقمي أو نتشتيت الطفل.

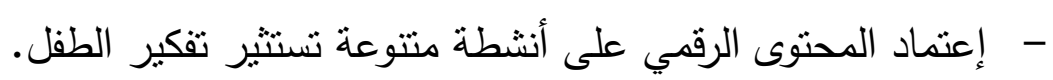
- ثبات مساحات الأيقونات المتكررة والعناوين الرئيسية والفرعية.

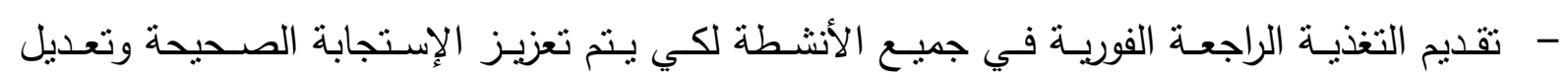
الخاطئة.

- شمول التقويم أجزاء الكتاب للتأكد من إحتفاظ الطفل بالدفاهيم التي سبق تعلمها.

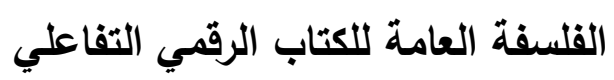
انثتقت فلسفة إعداد الكتاب الرقمي التفاعلي من أهمية إستغلال الثورة التكنولوجيـة التي فرضت

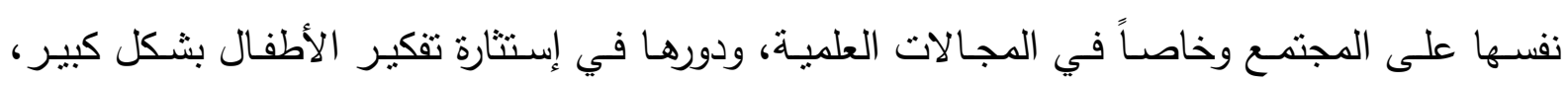

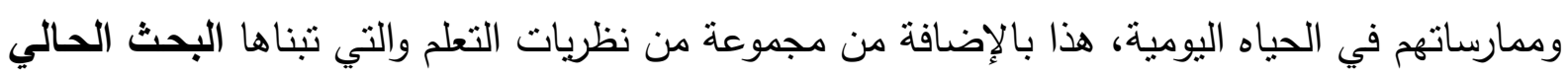
وهى كالتالي: - نظريـة برونر : وهي تعتمد على مبدأ بناء المعرفة والذي أكد فيها على تتظيم المادة العلمية بحيث

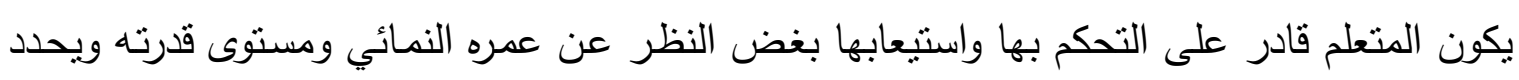

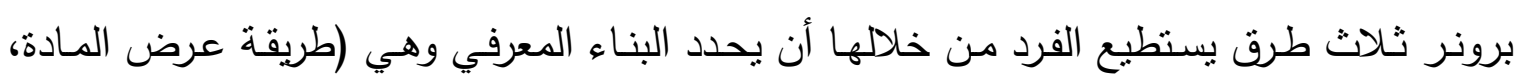
إقتصاديات العرض، فاعلية العرض). - نظرية أوزويل: وهي تعتمد على نموذج المنظمات التمهيدية يقوم على إفتراض أن البنية المعرفية من

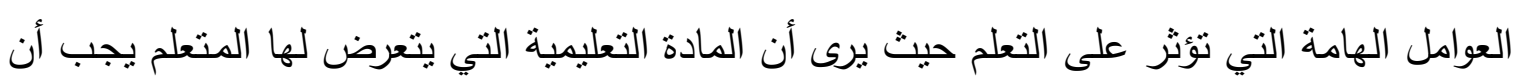

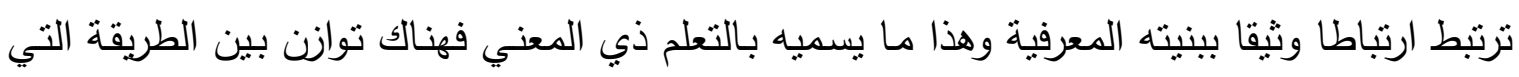

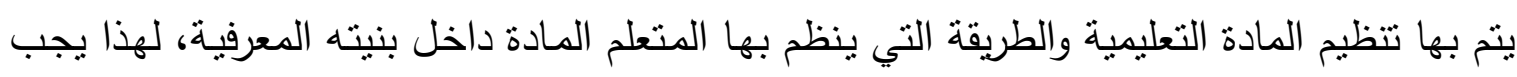

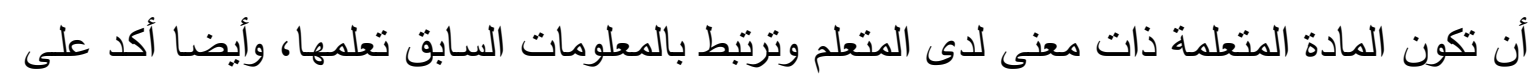

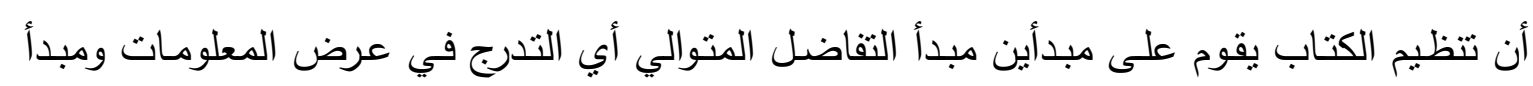
النوفيق التكاملي أي تنتوافق المعلومات الجديدة مع المعلومات السابق تعلمها. 
- - نظريـة بياجية للنمو العقلـي المعرفي: وهي تؤكد على التعلم الحسي وتتظيم العمل بالإنتقال من خطوة إلى الخطوة التي تليها، ويجب توفير الأنشطة التعليمية بشكل يتتاسب مع خصائص الأطفال

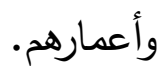
خطواط إعداد الكتاب الرقمي التفاعلي قامت الباحثة بتصميم كتاب رقمي تفاعلي في ضوء نموذج التصميم التعليمي الذي يتضمن المراحل الثالية: - n ا. مرحلة الإعداد: تم تحديد خصائص الأطفال والإعتبارات الأساسية في تعليمهم حتى يتم بناء الكتاب بثكل مناسب لهم، ثم تحديد الأهداف العامة والتي من خلالها تم وضع المحتوى التعليمي الذي سيقدم

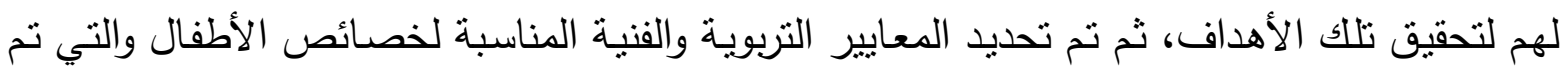
من خلالها الحكم على مدى صلاحية استخدام الكتاب الرقمي معهم.

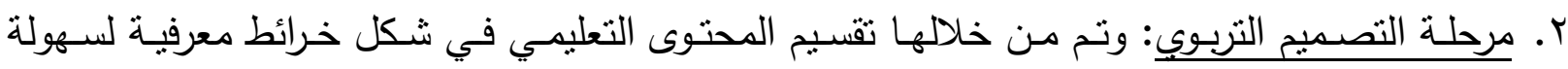

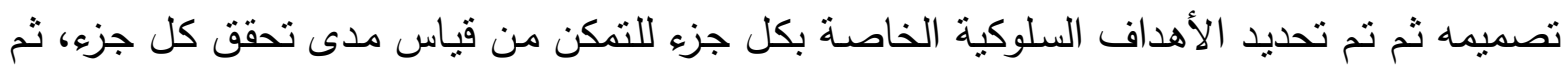

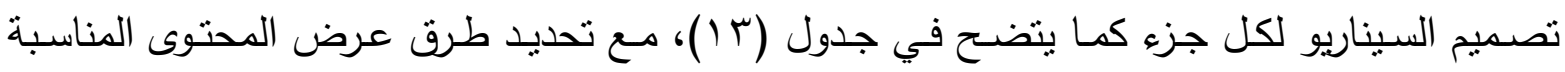
للأطفال وكذلك أساليب التقويم والتغذية الراجعة المناسبة. 


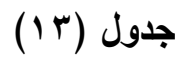

عرض لنموزج من سيناريو الكتاب الرقمي التفاعلي

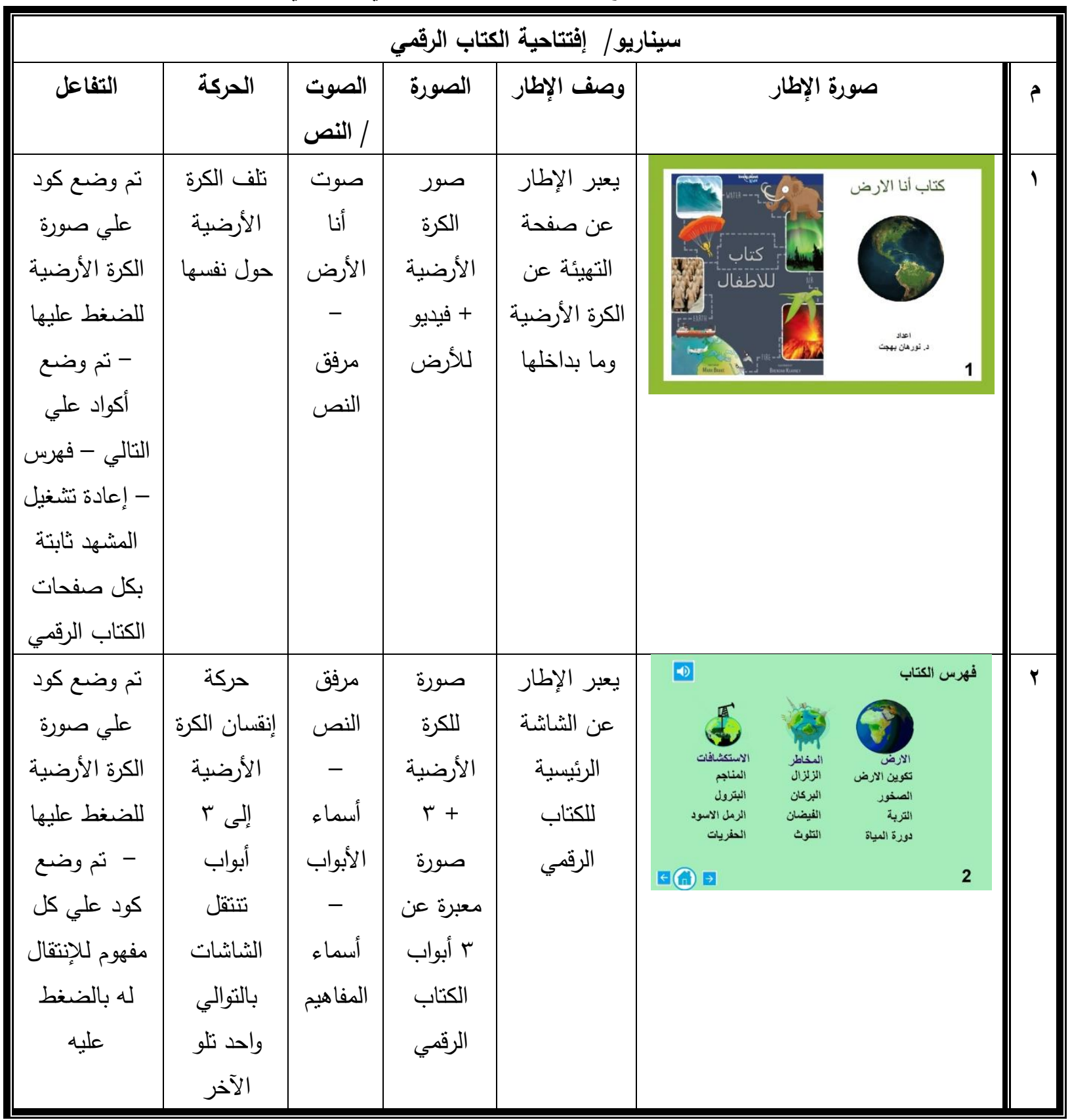

r. مرحلة التصميم الفني: وتم فيها إختيار البرامج التي أستخدم، ثم إعداد الرسوم الخاصة بكل جزء بإستخدام برنامج (بوربوينت PowerPoint - موفي ماكر Photoshop ونم مراعاه معايير تصميم الصور والرسوم التي تم تحديدها مسبقا، كذلك تم تسجيل

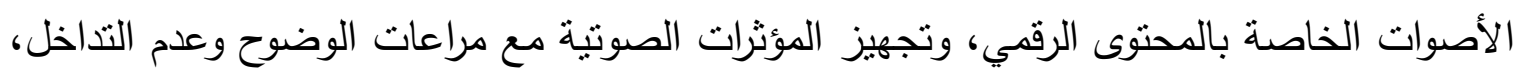

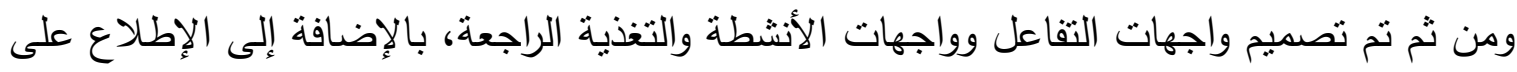
عدد من الكتب الرقمية المصصمة للأطفال للإستفادة من خطوات تصميمها مثل: 


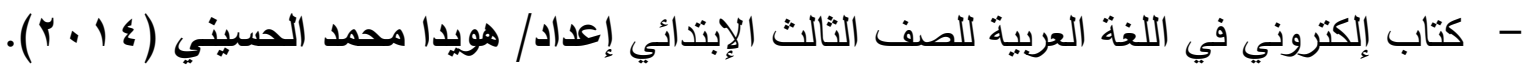
- كتاب إلكتروني تفاعلي في التأهيل اللغوي لضعاف السمع في مرحلة رياض الأطفال إعداد/ نجلاء

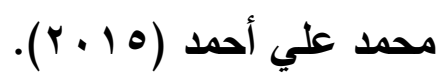

- كتاب إلكتروني تفاعلي لتتمية بعض مجالات التعلم للأطفال المعاقين عقلياً القابلين للتعلم إعداد/

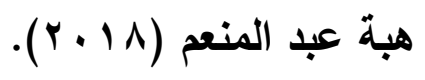

ـ. مرحلة الإنتاج: وتم فيها تجميع واجهات التفاعل داخل الكتاب الرقمي وعمل التزامن المناسب بين

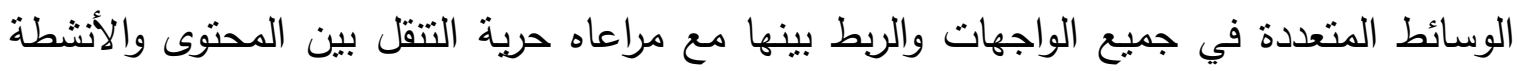

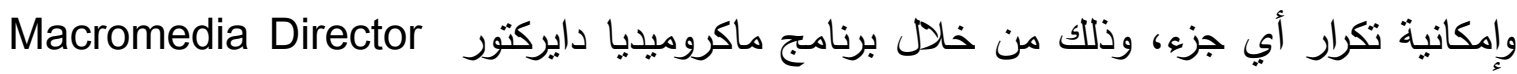
.Mx 2004

0. مرحلـة الإستخدام: وتم فيها طبع الكتاب ورقيا بالكامل وعرض الكتاب الورقي والرقمي مـع دليل

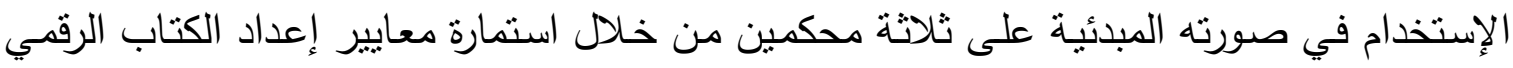
وإيجاد النسبة المئوية للمحكمين لآرائهم من حيث: - - الاهداف العامة، والأهداف السلوكية. - - مدى إرتباط محتوى البرنامج بأهدافه.

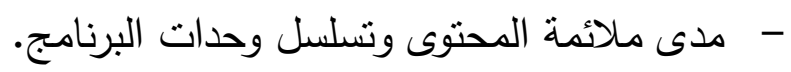
- - مدى ملائمة المحتوى وتسلسل وحدات البرنامج.

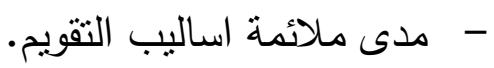

\section{ولقد تلخصت آراء المحكمين فيما يلي:}

إمكانية تحقيق أهداف الكتاب الرقمي من خلاءل هذا الكتاب المصمم وإرتباط المحتوى بأهداف الكتاب

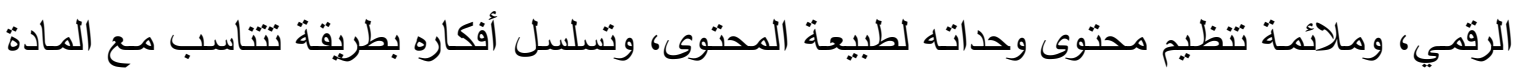

التعليمية، وقد تم التعديل وفقا لآرائهر:

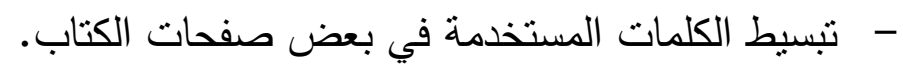
- - وضع صوت قلب الصفحة على الأسهم التالي والسابق. - تعديل لون الخلفية ليتناسب مع عمر الطفل.

الدراسة الإستطلاعية

بعد إجراء التعديلات التي أقرها السادة المحكمين على الكتاب الرقمي التفاعلي قامت الباحثة بإجراء

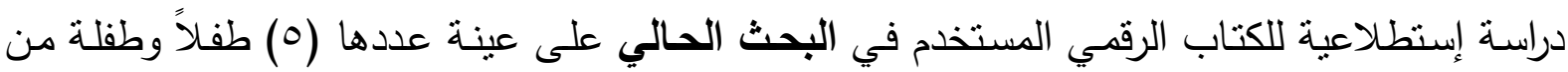
أطفال الروضة وذلك للتأكد من: - مدى سهولة ووضوح محتوى الكتاب، نطبيق أنثطة البرنامج. - مدى مناسبة زمن الأنشطة مع محتوي صفحات الكتاب. 


$$
\text { - مقدى مناسبة أساليب التقويم في برنامج الأنشطة. }
$$

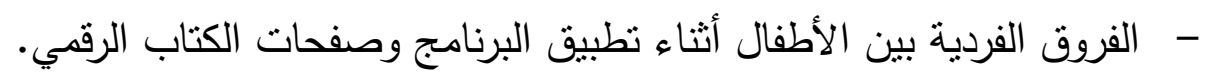

$$
\text { - - وضوح الجمل والكلمات المصاحبة لصفحات الكتاب. }
$$

- - أن تكون التطبيقات على كل مفهوم نشاط ومعلومة ولا يتم الجمع بينها في نهاية الباب مراعاه لعمر

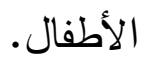

وفي ضوء الخطوات السابقة، وما تم الأخذ به من ملاحظات ومقترحات، أصبح الكتاب في صورته

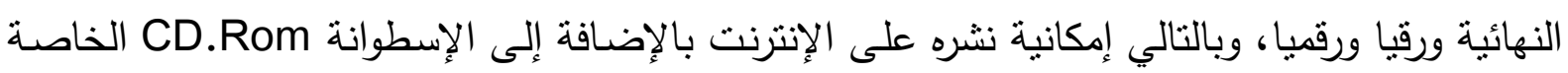
به، وتطبيقه على الأطفال عينة البحث.

مخطط جلسات انثطة الكتاب الرقمي التفاعلي لتنمية الثقافة الجيولوجية لأطفال الروضة التطال

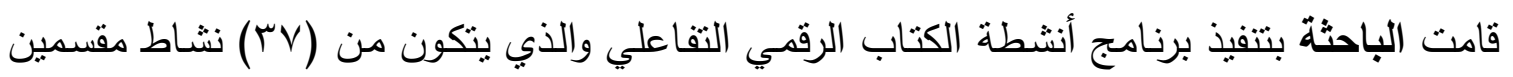

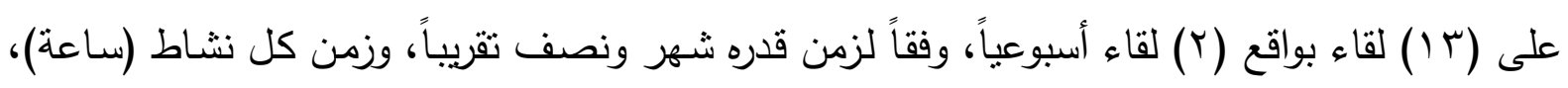
كما هو موضح في جدول (乏)

\begin{tabular}{|c|c|c|c|c|c|}
\hline \multicolumn{2}{|c|}{ التاريخ } & \multirow{2}{*}{ المكان } & \multirow{2}{*}{ عدد العينة } & \multirow{2}{*}{ الهدف } & \multirow{2}{*}{ الإجراءات } \\
\hline إلى & من & & & & \\
\hline$r \cdot 19 / 1 \cdot / r$ & $r .19 / 9 / r^{\prime} q$ & الروضلة & الأساسة البحثة & المقياس و الكتاب و والبرنامج مدائمة & الاستطلاعية \\
\hline$r .19 / 1 \cdot / 1 \cdot$ & $r \cdot 19 / 1 \cdot / V$ & النشاط & 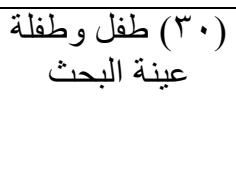 & وحلى عينة البحث القيات الأساسية القبلية & القباس \\
\hline$r .19 / 11 / r$. & $r \cdot 19 / 1 \cdot / 1 r$ & وخارج & (التجمينة البحثة & تنفيذ المجمو عة التجريبية & البرنامجيق \\
\hline$r \cdot 19 / 1 T / \varepsilon$ & $r \cdot 19 / 1 r / r$ & النشاط & 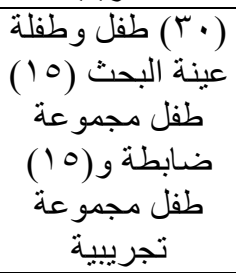 & تنفيذ متغير ات البيقت أنشطة بعد & البعدى البعاس \\
\hline
\end{tabular}

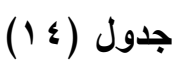

البرنامج الزمنى لإجراءات البحث

تطبيق أنثطة الكتاب الرقمي التفاعلي

قامت الباحثة بتطبيق الأنشطة على أطفال عينة البحث، حيث يجلس الطفل أمام شاشـة الكومبيوتر ويبدأ يتفاعل مع صفحات الكتاب ويمارس التطبيقات المطلوبة منه وفقا لكل مفهوم على حدى، ثم قامت التهن 
الباحثة بالإستعانة بالطالبات المعلمات لتطبيق الأنشطة المصاحبة لكل مفهوم على الأطفال، وذلك

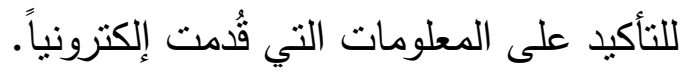

\section{وسائل تقويم برنامج أنشطة الكتاب الرقمي}

قامت الباحثة بإستخدام وسائل أساليب التقويم التالية:

- تقويم قبلي: وذلك من خلال تطبيق مقياس البحث على الأطفال قبل تطبيق البرنامج لمعرفة مستواهم الفعلي وما لديهم من معلومات عن مفاهيم الثقافة الجيولوجية. - تقويم بنائي: وهو مصاحب من بداية تطبيق البرنامج لنهايته من خلال التطبيقات التربوية الرقمية

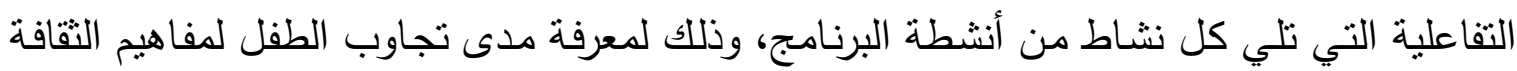
الجيولوجية. - تقويم بعدي: وذلك من خلال إعادة تطبيق مقياس البحث على الأطفال بعد تطبيق البرنامج لمعرفة

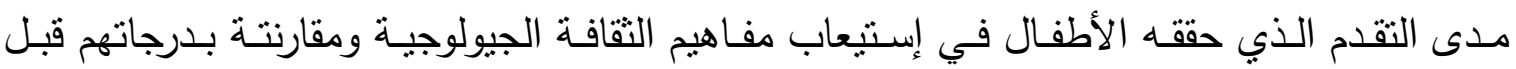

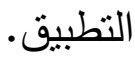

وفيما يلى عرض لإحدى أنثطة الكتاب الرقمي للبحث الحالي

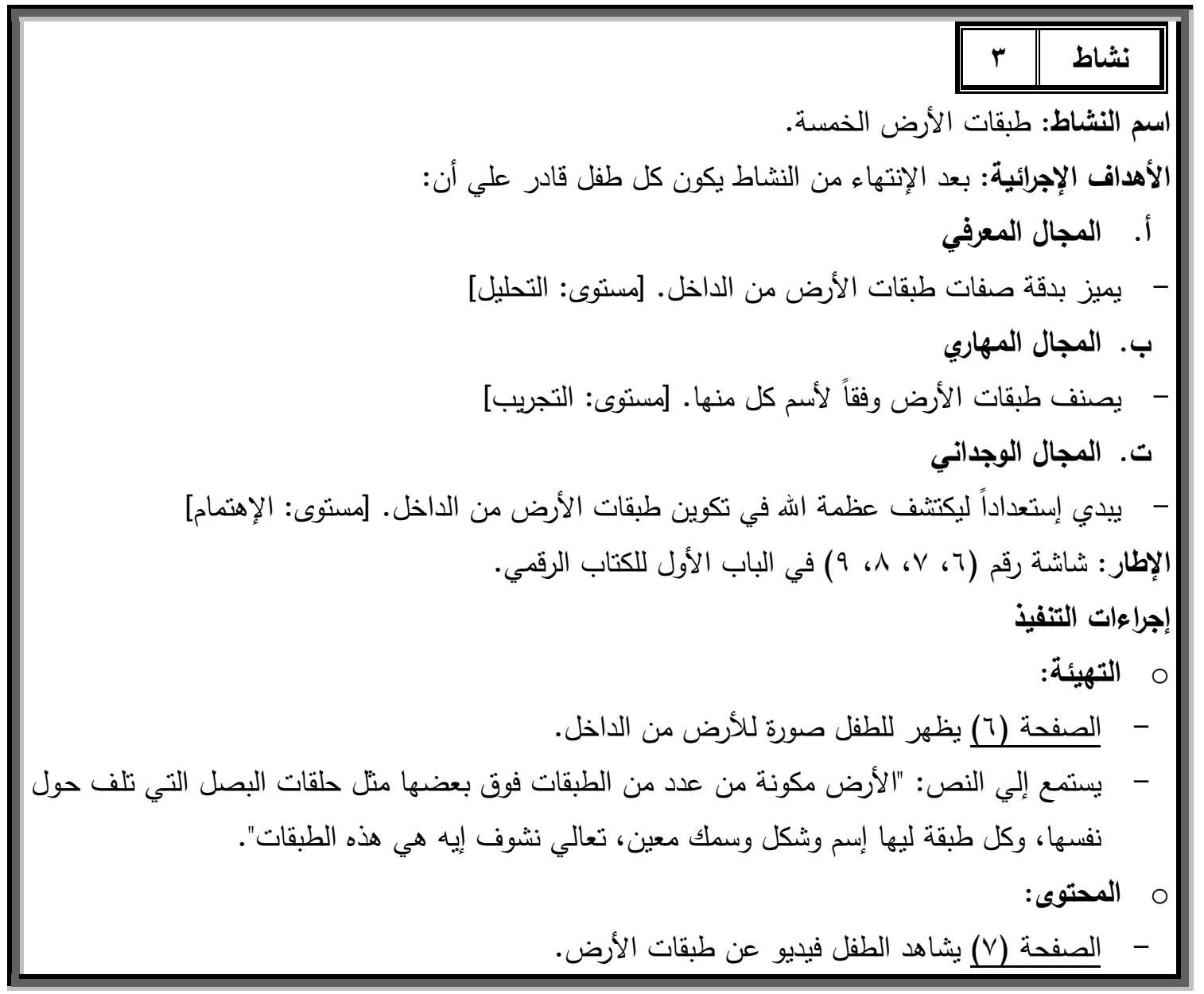




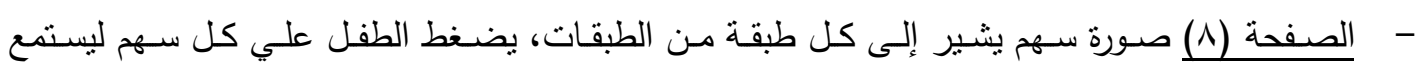
لمعلومات عن كل طبقة علي حدى.

يستمع الطفل إلي النص: الطبقة الاولي اسمها القشرة: وهي رقيقة جدا وديه التي نعيش عليها، والطبقة

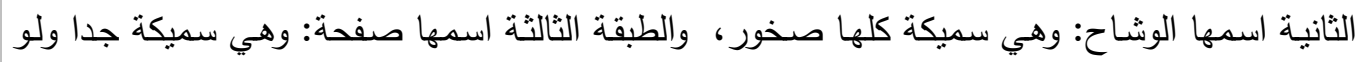
اتحركت من مكانها تعمل الزلزال، أمسا الطبقة الرابعة تسمي اللب الخارجي: وهى سـاخن جدا ودهه إلي بيحمي الأرض من انتعة الثمس الحارقة، والطبقة الخامسة: تسمي النواه وهي ساخنة جدا أيضا". O - الصفحة (9) يقوم الطفل بتصنيف طبقات الأرض كل طبقة أمام أسمها بالضغط علي الصورة. - ميستمع الطفل إلى النص: "إضغط على صورة طبقة القشرة وطبقة النواه بداخل الكرة الأرضية". وعرض لإحدى الأنثطة المصاحبة لمفاهيم الكتاب الرقمي للبحث الحالي

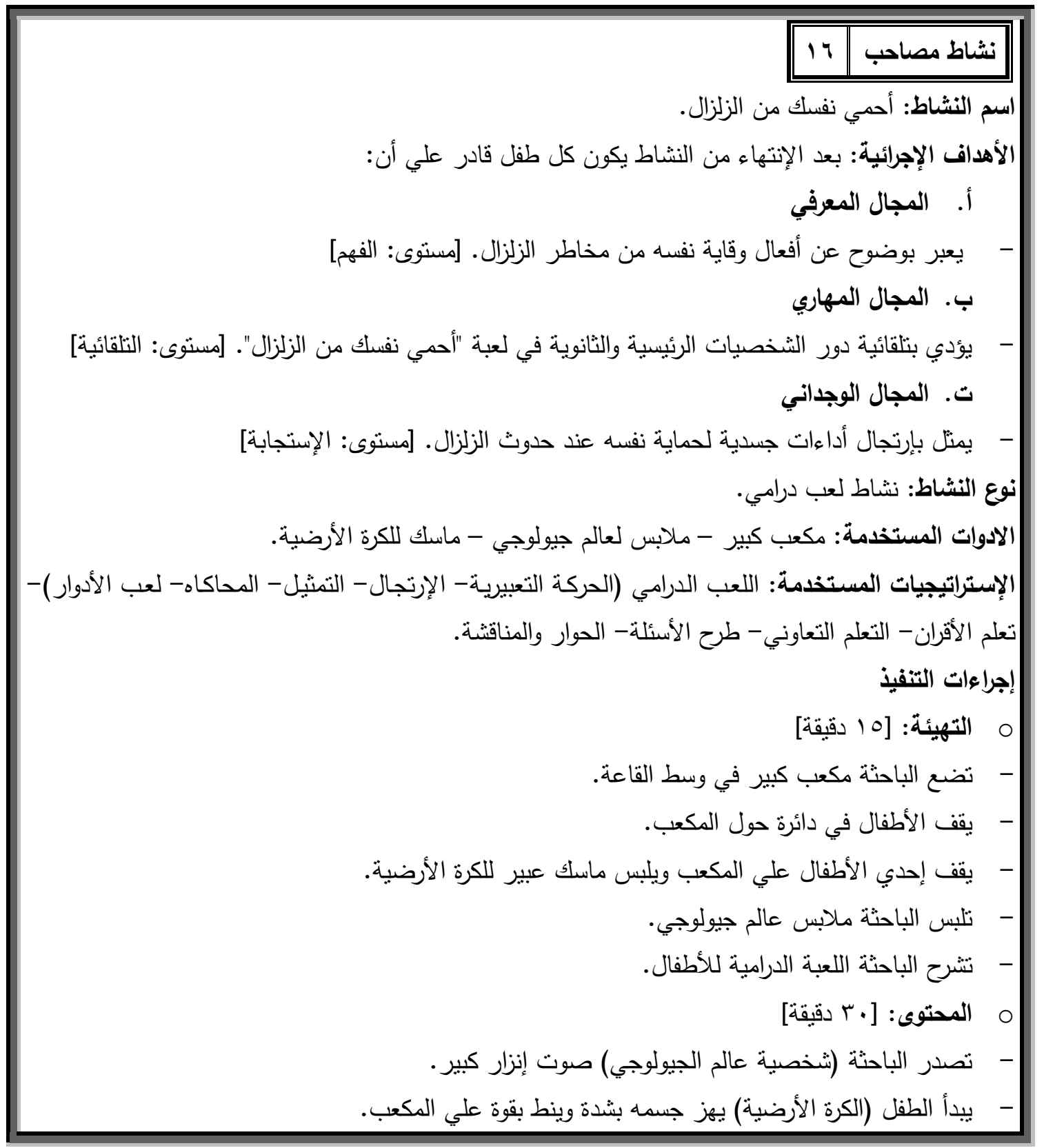




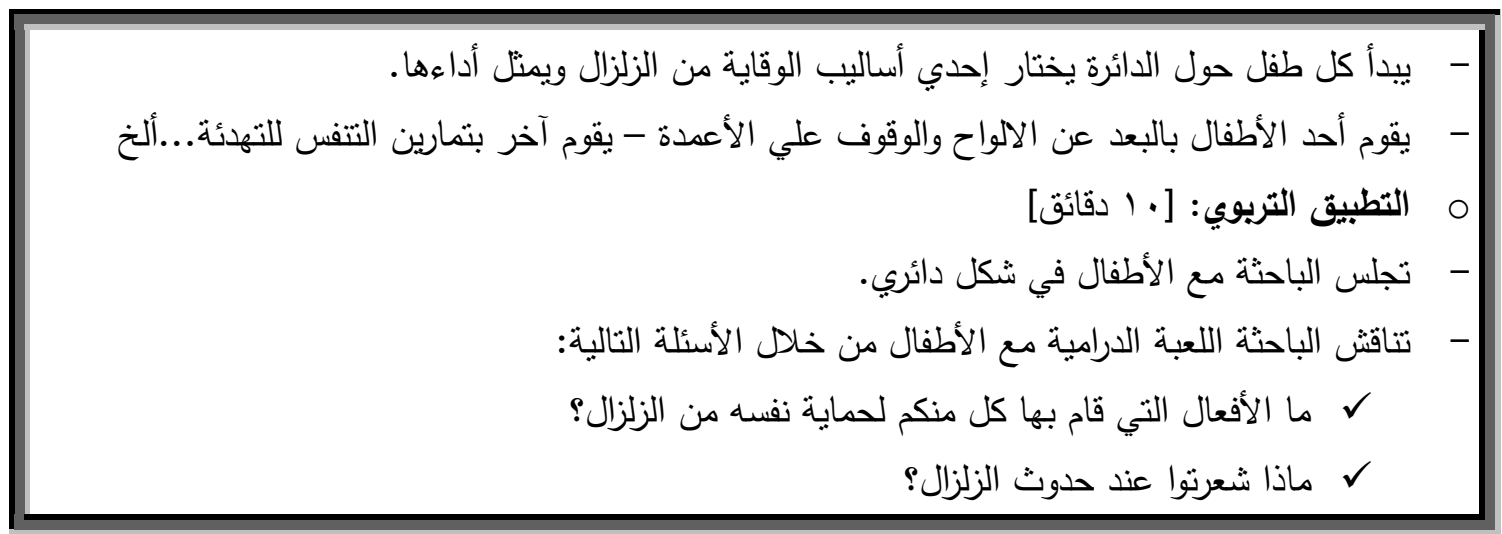

وفيما يلى عرض لبعض الصور التي توضح مشاركة الأطفال عينة البحث في أنثطة الكتاب الرقمي الحالي

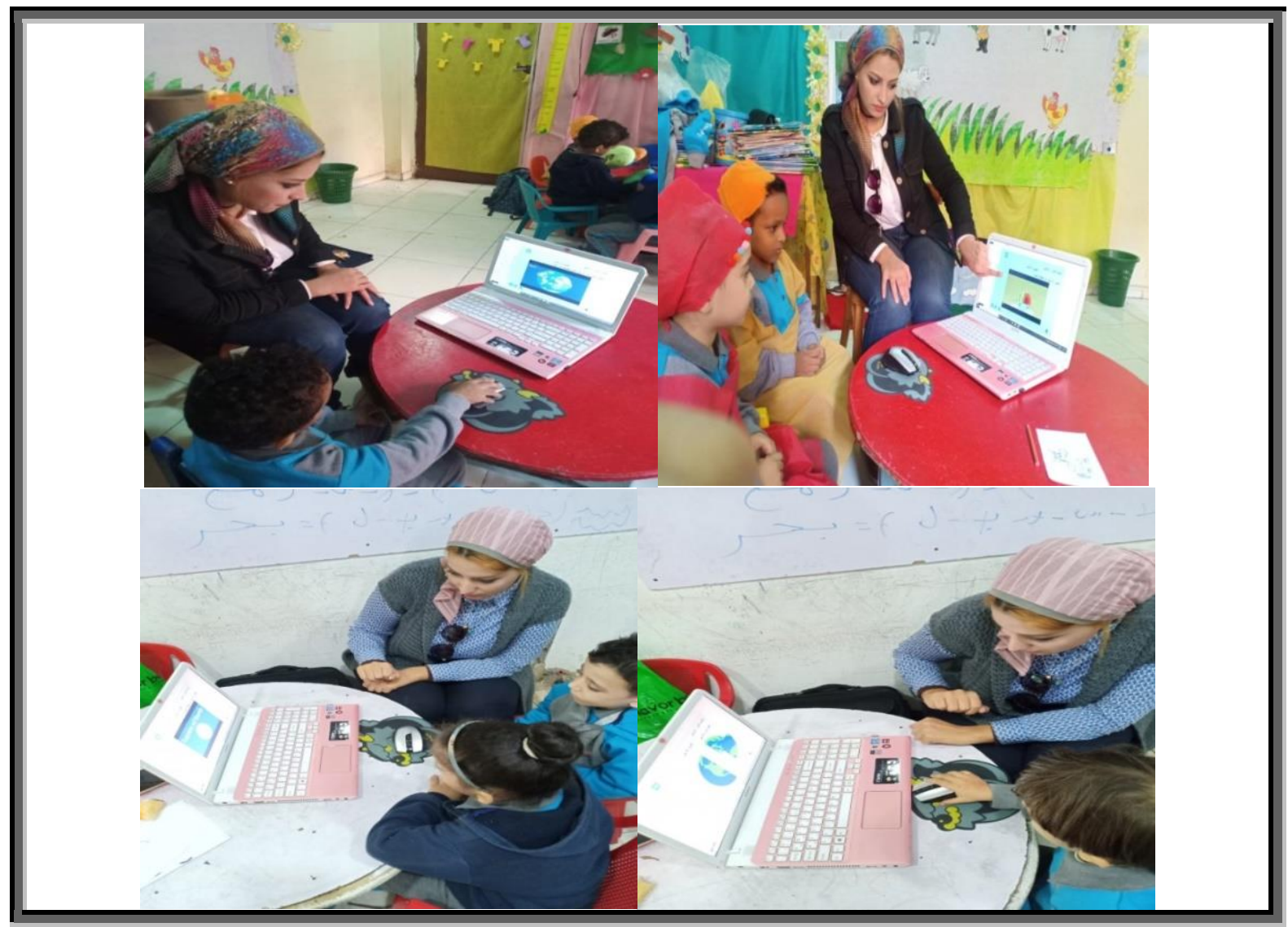




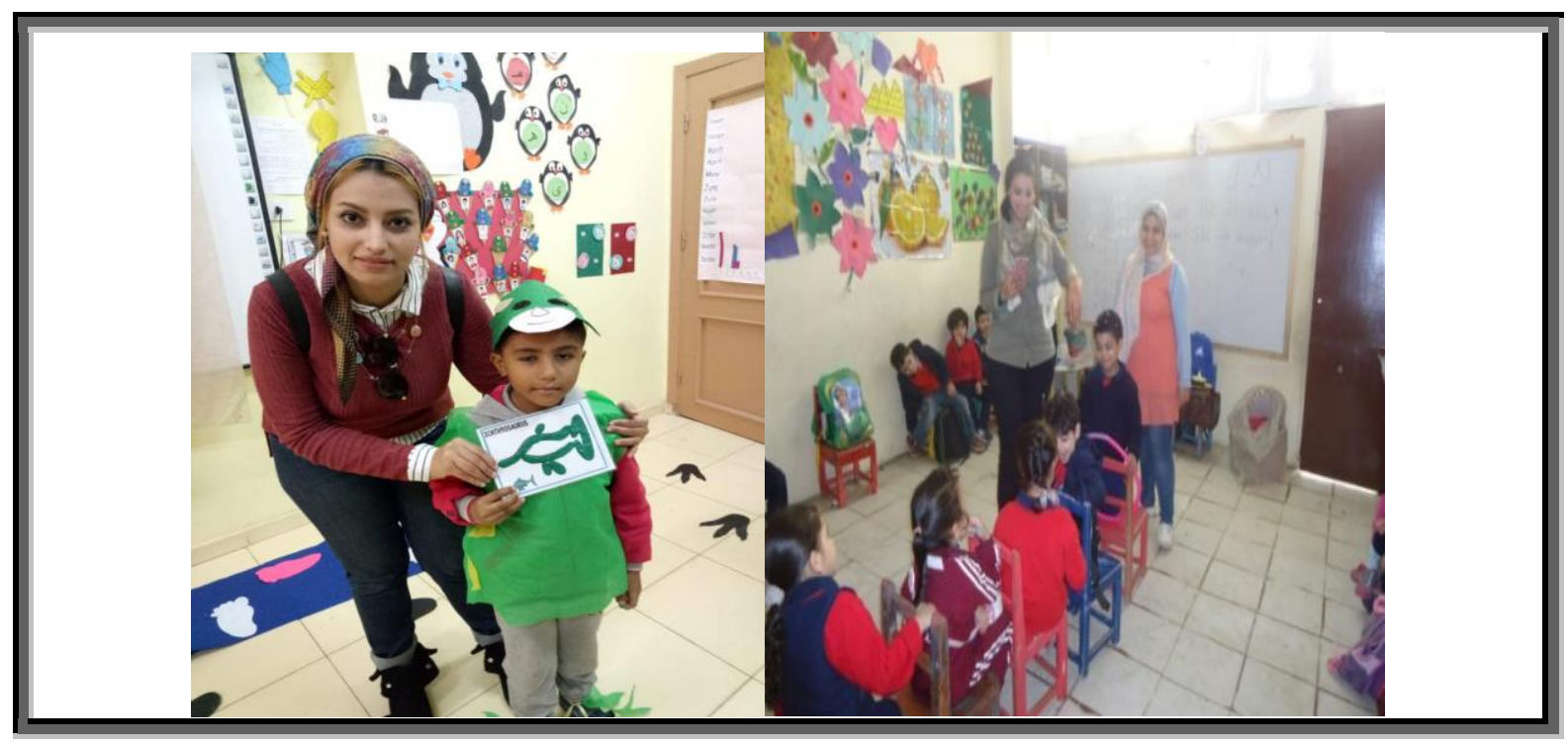

المعالجة الإحصائية

عرض النتائج وتفسيرها: نتائج الفرض الاول

يــص الفـرض الاول على انسه: "توجـد فـروق ذات دلالـة إحصـائية بـين متوسـطي رتـب درجـات

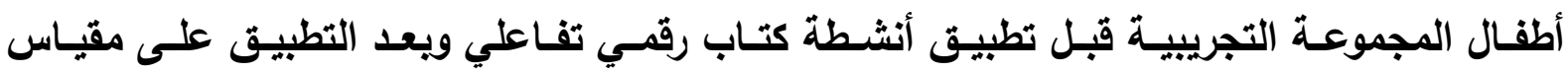
الثقافة الجيولوجية لأطفال الروضة لصالح القياس البعدى".

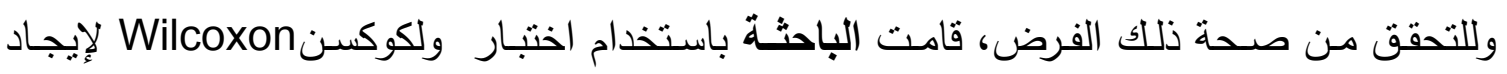

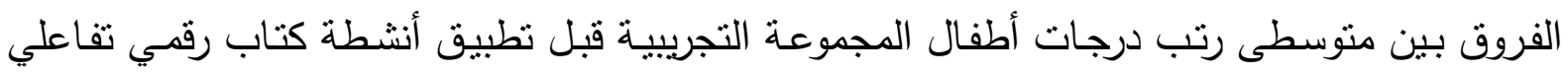

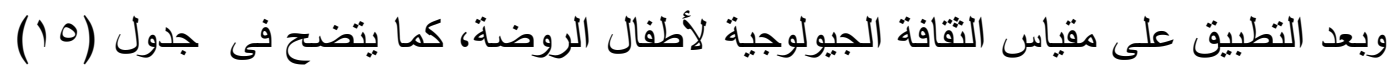




\section{جدول (10)}

الفروق بين متوسطى رتب درجات أطفال المجموعة التجريبية قبل تطبيق أنثطة كتاب رقمي تفاعلي ويعد التطبيق على مقياس الثقافة الجيولوجية لأطفال الروضة

\begin{tabular}{|c|c|c|c|c|c|c|c|}
\hline اتجاه الدلالة & الالالة & $\mathbf{Z}$ & مجموع & متوسط الرتب & العدد & القبلى - البعدى القياس & المتغيرات \\
\hline في التجاه & مستوى Iالة عند & $r . r \varepsilon r$ & $\begin{array}{l}- \\
1 Y\end{array}$ & $\begin{array}{l}- \\
\Lambda\end{array}$ & $\begin{array}{l}- \\
10 \\
- \\
10\end{array}$ & $\begin{array}{r}\text { الرتب السالبة الرتب الموجبة المتساوية } \\
\text { الربّة } \\
\text { الرتبة }\end{array}$ & الارض \\
\hline فى اتجاه & مستوى د الة عند & r. $\tilde{\mu}$ V & $\begin{array}{l}- \\
1 Y\end{array}$ & $\begin{array}{l}- \\
\wedge\end{array}$ & $\begin{array}{l}- \\
10 \\
- \\
10\end{array}$ & الرتب السالبة الرتب المبتبة المتساوية & المخاطر \\
\hline فى اتجاه & مستوى الة عند & ו & $\begin{array}{l}- \\
1 Y\end{array}$ & - & $\begin{array}{l}- \\
10 \\
- \\
10\end{array}$ & 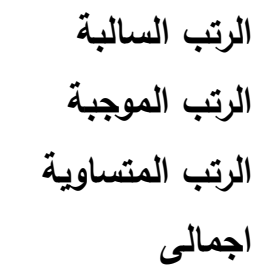 & الاستكشاقات \\
\hline فى اتجاه & مستوى الة عند & r.£। & $\begin{array}{l} \\
\text { Ir. }\end{array}$ & $\begin{array}{l}- \\
\Lambda\end{array}$ & $\begin{array}{l}- \\
10 \\
- \\
10\end{array}$ & الرتب السالبة الرتب الموجبة المتساوية & اللرجة الكلية \\
\hline
\end{tabular}

... 0 1.97 =

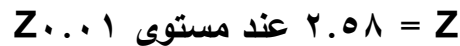

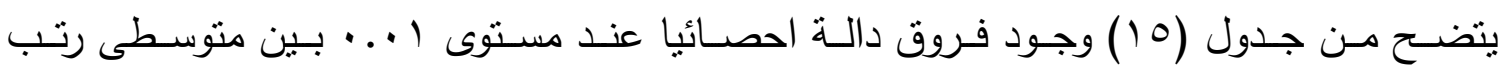

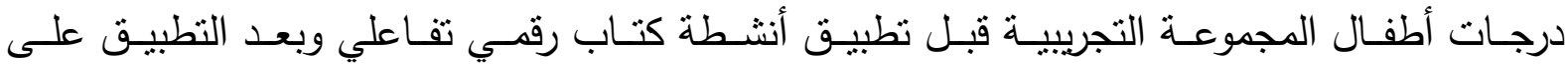
مقياس الثقافة الجيولوجية لأطفال الروضة فى اتجاه القياس البعدى.

ويوضــح شـكل (ب) الفـروق بـين متوسـطى رتــب درجـات أطفــال المجموعـة التجريبيـة قبـل تطبيـق أنشـــة كتـاب رقمـي تفــاعلي وبعـد التطبيـق علـى مقيـاس التقافـة الجيولوجيـة لأطفــال الروضة. 


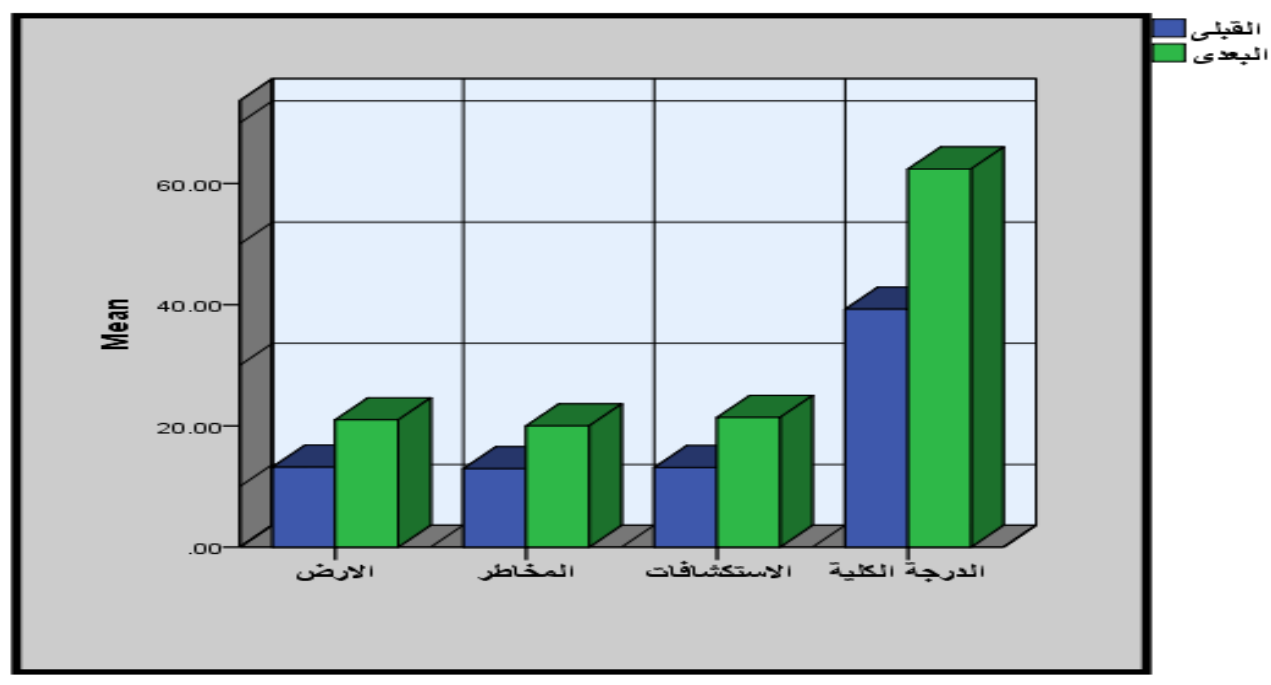

شكل (r)

الفروق بين متوسطى رتب درجات أطفال المجموعة التجريبية قبل تطبيق أنثطة كتاب رقمي تفاعلي وبعد التطبيق على مقياس الثقافة الجيولوجية لأطفال الروضة

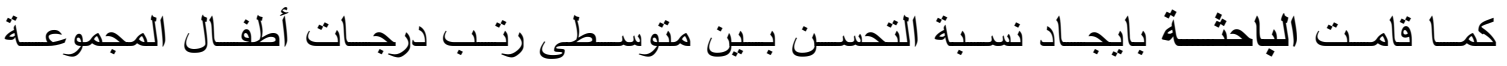

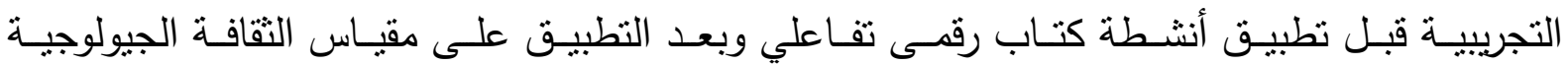

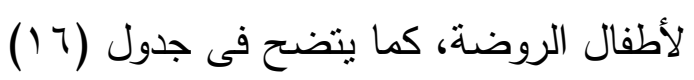
جدول (14)

نسبة التحسن بين القياسين القبلى و البعدى لتطبيق أنثطة كتاب رقمى تفاعلي على مقياس الثقافة الجيولوجية لأطفال الروضة المطئ

\begin{tabular}{|c|c|c|c|}
\hline نسبة التحسن & متوسط القياس البعدى & متوبط القياس القبلى & المتغيرات \\
\hline$\% r v .1 \leq$ & r & Ir.r & الارض \\
\hline \%ro.ro & $r$. & 1r.qr & المخاطر \\
\hline \%r^.ฯ & r..s & $1 r .14$ & الاستكثافات \\
\hline$\%$ \% ... & Tr.s & rq.rq & الدرجة الكلية \\
\hline
\end{tabular}

تُرجِع الباحثة تحقق صحة الفرض الأول للبحث الحالي إلى تفوق أطفال المجموعة التجريبية في

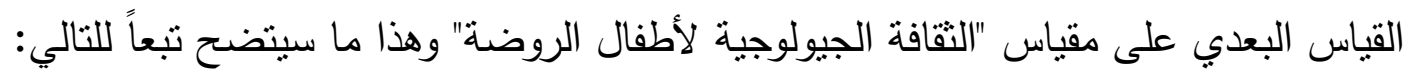
- فاعلية الكتاب الرقمي التفاعلي في تحقيق تقدم ملحوظ في إكتساب مفاهيم الثقافة الجيولوجية لأطفال الروضة، حيث ساهم الكتاب في تتمية الجانب المعرفي والمهاري والوجداني للمفاهيم المرتبطة بيعد

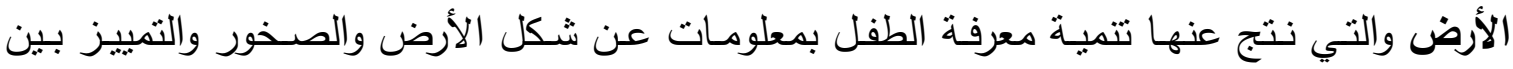
الأنواع، وإكتشاف عظمة الله في تهيئة الكرة الأرضية للحياه، وأهمية المياه والتربـة لحياه الكائنات

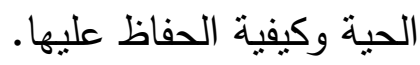


- كما تَمَكْن الكتاب الرقمي من تتمية المفاهيم المرتبطة ببعد المخاطر المهددة للأرض والتي نتج عنها

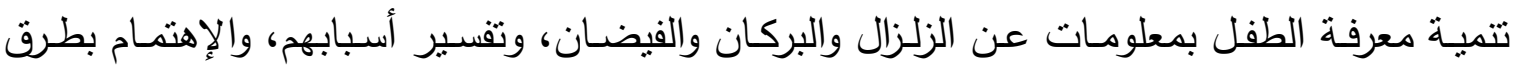

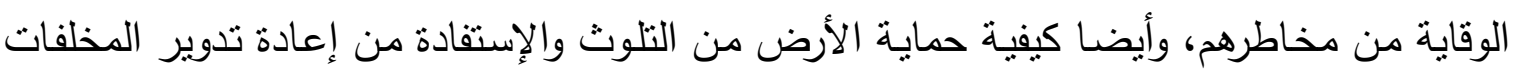

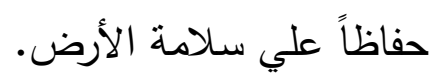

- كما كان للكتاب الرقمي التفاعلي النسبة الأكبر في التحسن بين الأطفال في تتمية الدفاهيم المرتبطة

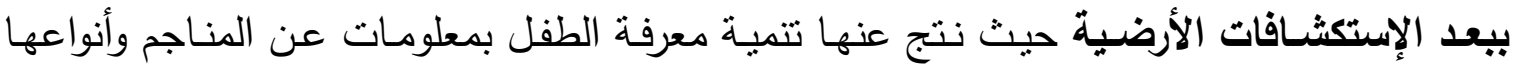

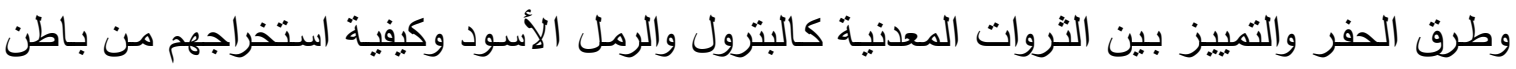

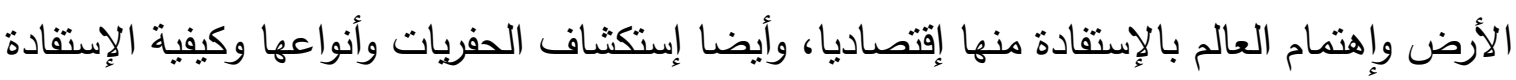
منها في معرفة تاريخ الأرض. وتُعدد الباحثة أسباب تفوق أطفال المجموعة التجريبيـة في القياس البعدي لعدة أسباب هي

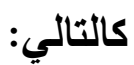
- قُدمت المفاهيم في الكتاب الرقمي بشكل تدريجي فتم عرض المعلومات المألوفة للطفل أولاً ثم الأكثر

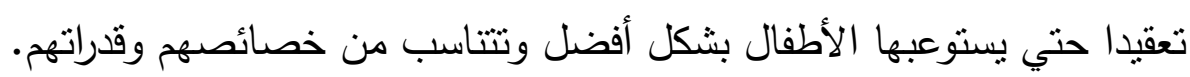

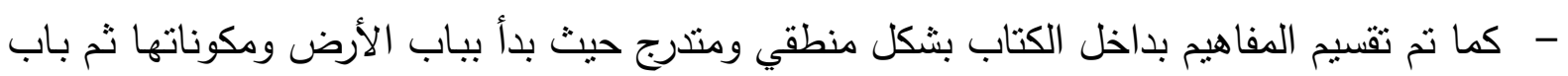
المخاطر وظواهرها ثم باب الإستكثافات وفوائدها وكل منهم يحتوي على أربعة مفاهيم فرعية مرنبطة

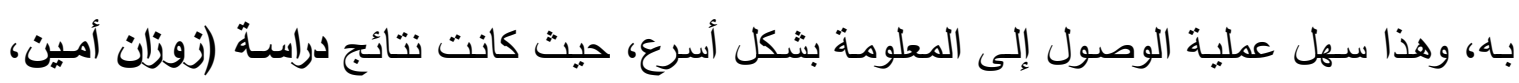

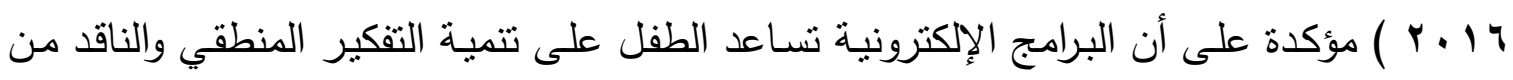
خلال تصنيف العلوم الجيولوجية بشكل يسهل إسترجاعه.

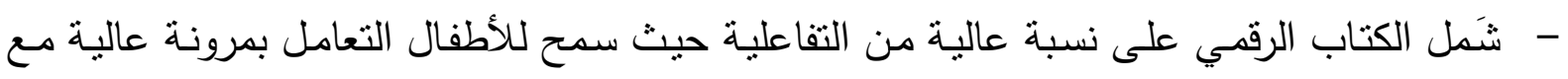
صفحات الكتاب، فإعتمد المحتوى التعليمي على الصور والرموز الدالة والبسيطة التي ساعدت الطفل الطفل على التذكر والفهم والربط بين المفاهيم والمعلومات وبقاء آثارها لفيدا لفترة أطول.

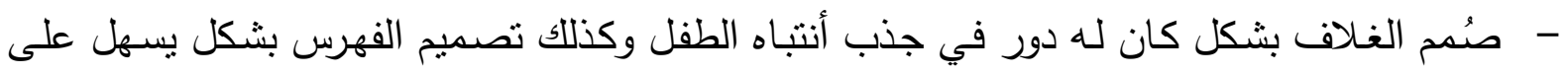

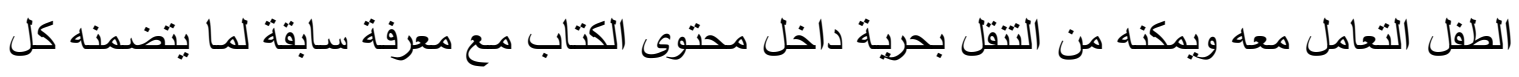

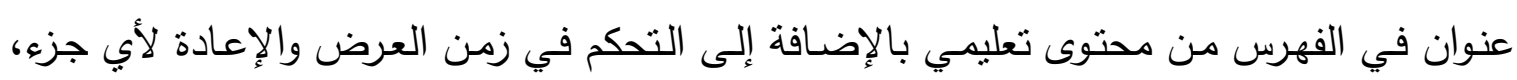

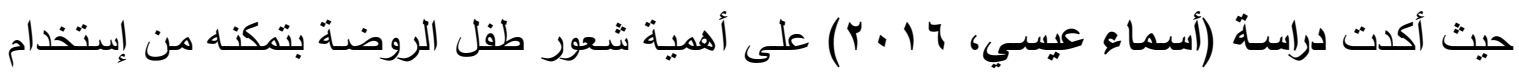
المحتوى الإلكتروني (الكتاب الرقمي) وبالتالي زادت نقته بنفسه وتحفيزه للإستمرار في التعلم.

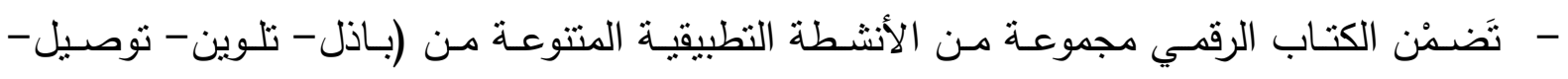

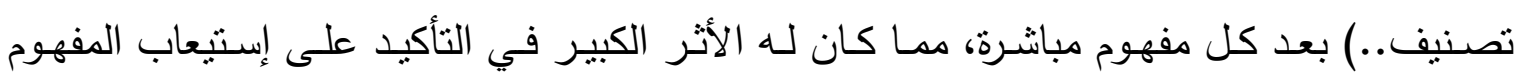

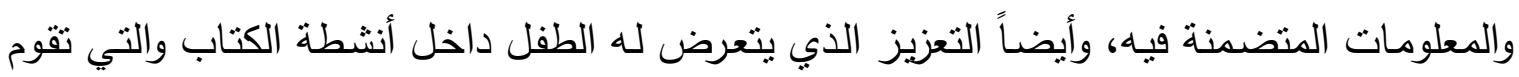
بتعزيز الإستجابة الصحيحة والمساعدة في تعديل الإستجابة الخاطئة من خلال إستطاعته الرجوع إلى لى لئه 
المعلومات مرة آخرى ثم إعادة الإستجابة وهذا أعطي الطفل الإحساس بالقدرة علي الإستيعاب وسط

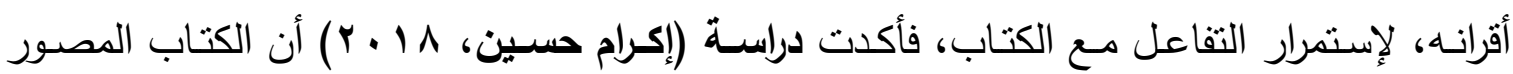

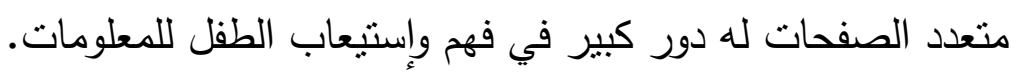

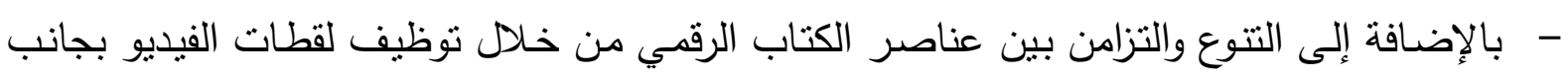

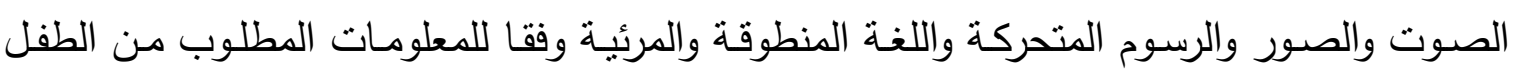

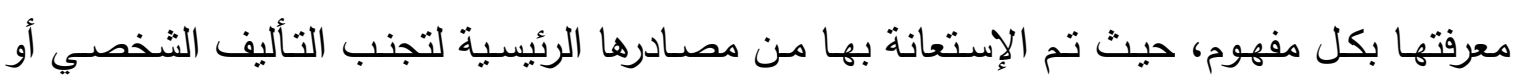
اللجوء لمعلومات أكبر من عمر الطفل.

- كما حرصت الباحثة علي تقسيم الكتاب بشكل منطقي علي شكل صفحات خلف بعضها وتتميز كل المل

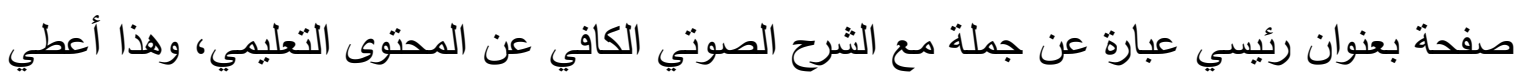

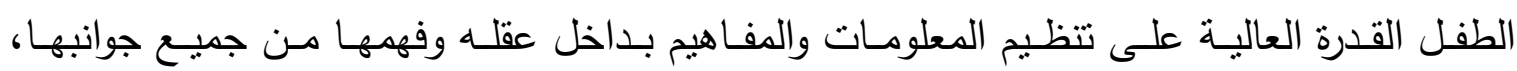

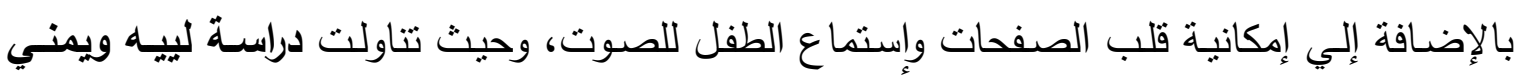
وسونيا (Leah Zhang\& Yomna\& Abdelaziz\& Sonia Chiasson, 2017) ضرورة تصميم الكتاب الرقمي على أنه ورقي ولكن بطريقة تفاعلية وجذابة، وهنا يُفنترض وجود نفس الكتاب مع الطفل ولكن في شكل ورقي.

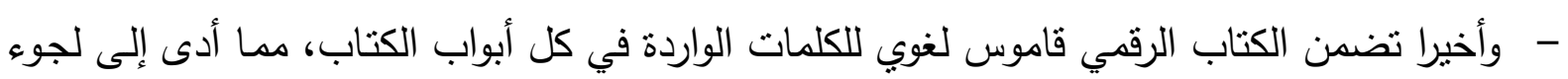

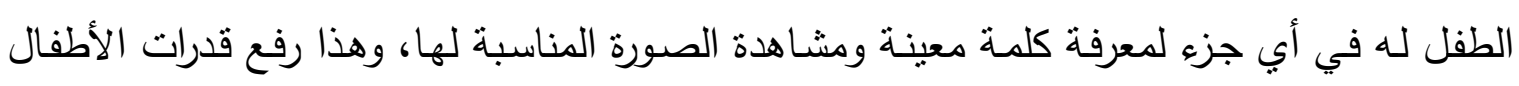

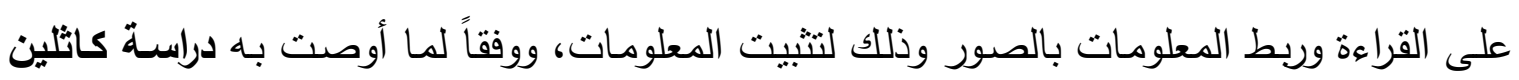

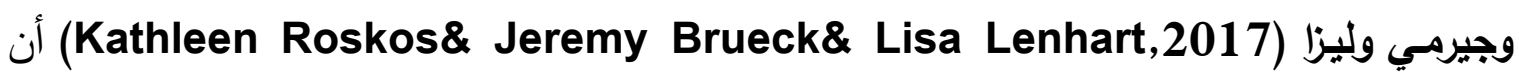
الهدف الأكبر من زيادة الكتب الإكترونية للأطفال هو حب القراءة بالطريقة الحديثة.

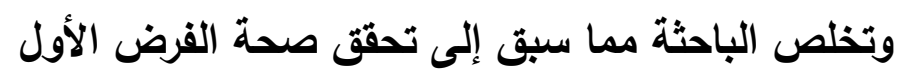
نتائج الفرض الثانى

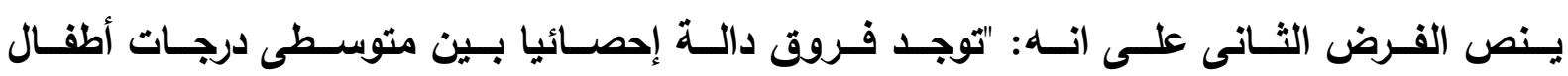

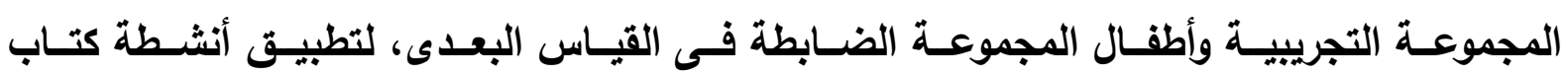
رقمى تفاعلي على مقياس الثقافة الجيولوجية لأطفال الروضة لصالح المجموعة التجريبية". ويتفرع منه الفروض الثالية: - - توجد فروق دالة إحصائية بين متوسطي درجات أطفال المجموعة التجريبية وأطفال المجموعة الضابطة فى القياس

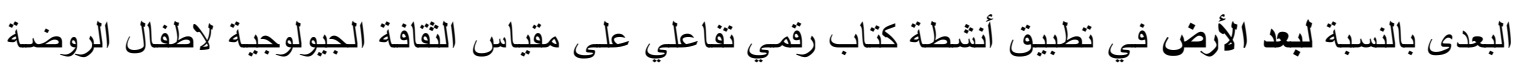
لصالح المجموعة النجريبية. توجد فروق دالة إحصائية بين متوسطي درجات أطفال الدجموعة التجريبية وأطفال الدجموعة الضابطة فى القياس

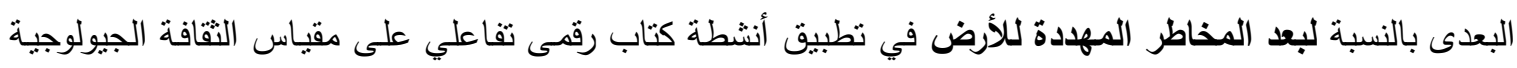
لاطفال الروضة لصالح المجموعة التجريية. 
- ـ توجد فروق دالة إحصائية بين متوسطي درجات أطفال المجموعة التجريبية وأطفال المجموعة الضـابطة فى القياس البعدى بالنسبة لبعد الاستكثـافات الأرضية في تطبيق أنشطة كتاب رقمى تفاعل على مقياس الثقافة الجيولوجية لاطفال الروضة لصالح المجموعة التجريبية.

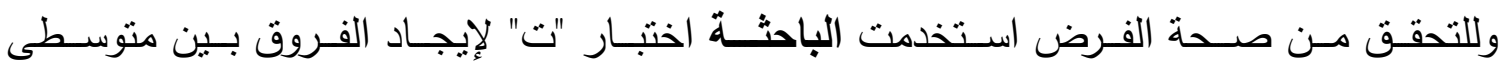
درجـات أطفـال المجموعـة التجريبيــة وأطفــال المجموعـة الضــابطة فـى القيـاس البعـدى، لتطبيــق

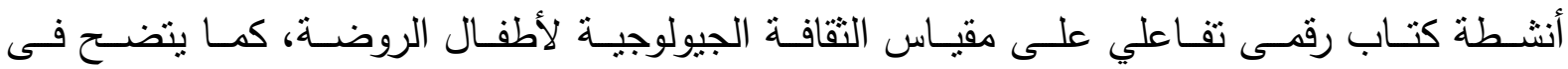
جدول (IV)

\section{جدول (IV)}

الفروق بين متوسطى درجات أطفال المجموعة التجريبية وأطفال المجموعة الضابطة فى القياس البعدى لتطبيق أنشطة كتاب رقمى تفاعلي على مقياس الثقافة الجيولوجية لأطفال الروضة

$$
\text { r. }
$$

\begin{tabular}{|c|c|c|c|c|c|c|c|}
\hline \multirow[t]{2}{*}{ اتجاه الدلالة } & \multirow[t]{2}{*}{ مستوى الدلاية } & \multirow[t]{2}{*}{ 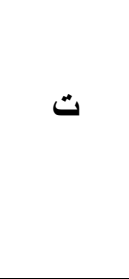 } & \multicolumn{2}{|c|}{ الضابطة } & \multicolumn{2}{|c|}{ التجريبية } & \multirow[t]{2}{*}{ المتغيرات } \\
\hline & & & $r \varepsilon$ & $t^{5}$ & $1 \varepsilon$ & م & \\
\hline لصالح التجريبية & دالة عند مستوى & 11.87 & $1.1 r$ & Ir.s & Y.Yr & r & الارض \\
\hline لصالح التجريبية & دالة عند مستوى & Ir.ov & 1.11 & $1 r .14$ & 1.00 & $r$. & المخاطر \\
\hline لصالح التجريبية & دالة عند مستوى & 17.49 & $1 . .1$ & Ir.A & 1.87 & Y. & الاستكشاقات \\
\hline لصالح التجريبية & دالة عند مستوى & $I V . \leqslant 0$ & r.79 & rq.rr & ס.r. & Tr.s & الارجة الكلية \\
\hline
\end{tabular}

$$
\text { ت = } 1.79 \text { عند مستوى }
$$

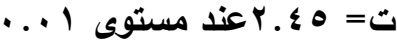

يتضـح مـن جـدول (IV) وجـود فـروق دالـة احصــائيا عنــد مسـتوى ا ... بــين منتوسـطى درجـات أطفـال المجموعـة التجربييـة وأطفــال المجموعـة الضــابطة فـى القيـاس البعـدى، لتطبيـق أنشـــة كتـاب رقمى تفـاعلي على مقيـاس الثقافـة الجيولوجيـة لأطفـال الروضــة لصـالح المجموعـة التجريبية .

ويوضــح شـكل (ع) الفـروق بــين متوســـي درجـات أطفــال المجموعــة التجربييــة وأطفــال المجموعـة الضـابطة فـى القيـاس البعـدى، لتطبيـق أنشـــة كتـاب رقمـى تفـاعلي علـى مقيـاس الثقافة الجيولوجية لأطفال الروضة. 


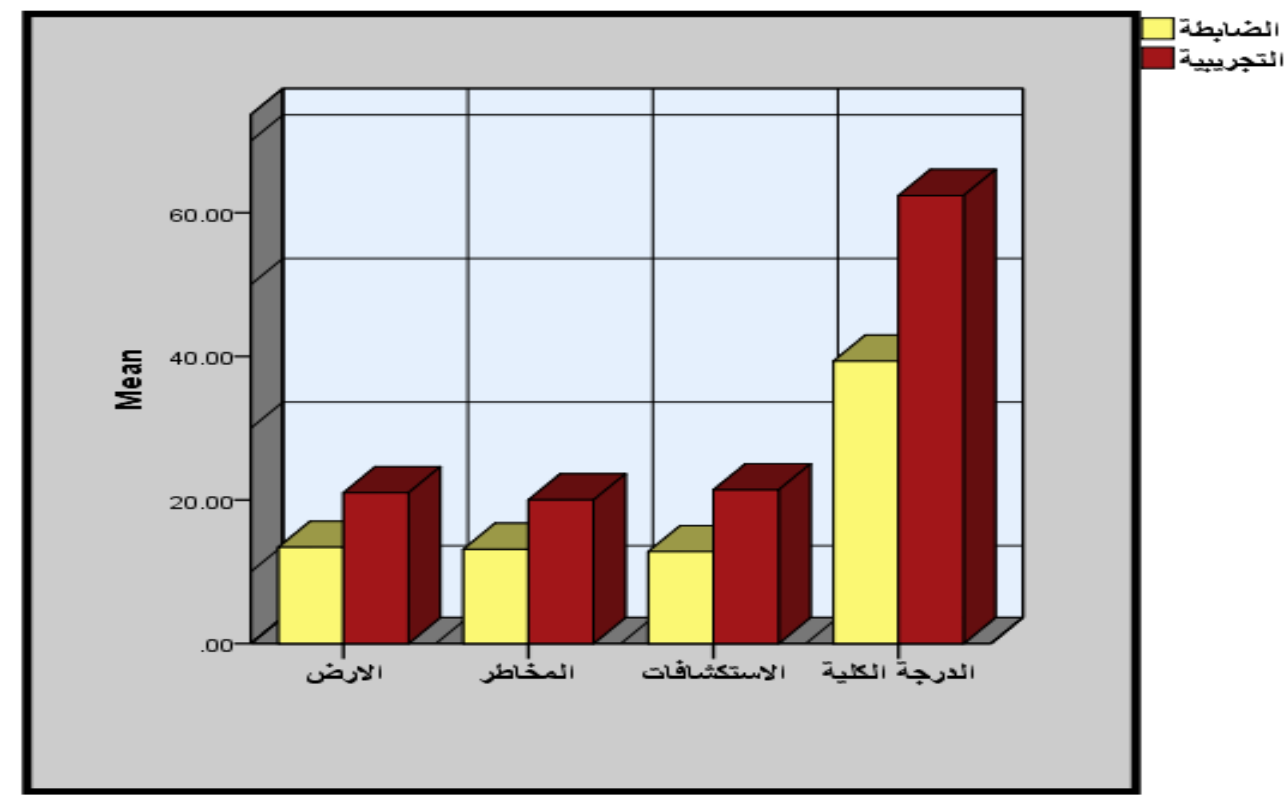

شكل (๕)

الفروق بين متوسطى درجات أطفال المجموعة التجريبية وأطفال المجموعة الضابطة فى القياس البعدى، لتطبيق

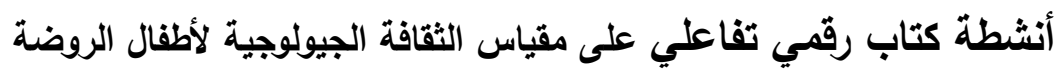
وتُرجع الباحثة تفوق أطفال المجموعة التجريبة عن أطفال المجموعة الضابطة على مقياس الثقافة الجيولوجية لأطفال الروضة إلى نجاح أنشطة كتاب رقمي تفاعلي فى اكتساب أطفال المجموعة التجريبية

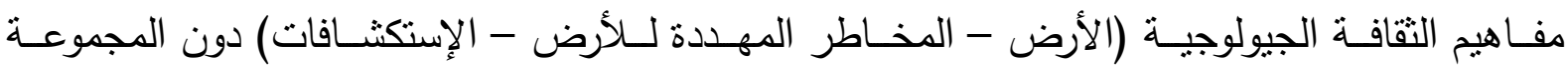

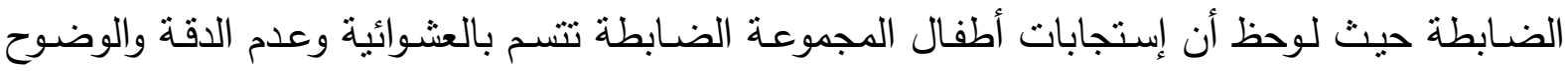
فكانوا لا يعرفون أسماء طبقات الأرض أو التربة ولا يستطيعون تفسير أسباب الظواهر أو كيفية الإستفادة

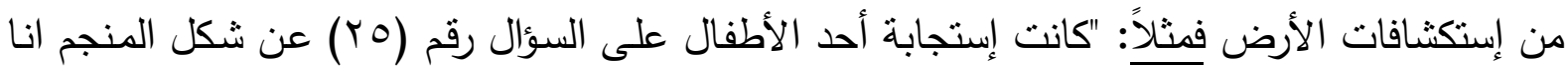

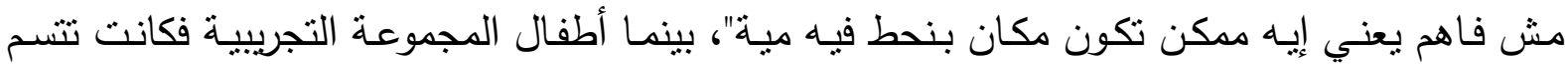
إستجاباتهم بالمعرفة الدقيقة والمنطقية لمكونات الأرض والظواهر المؤثرة عليها والربط بين المعلومات لئات وبعضها وأيضا تفسير أسبابها بشكل علمي بسيط ومعرفة مخاطرها وتجنبها وكيفية الأستفادة من الأثياء المستخرجة من الأرض، وكما أن هناك بعض الأطفال ربطوا تلك المفاهيم بحياتهم اليومية فمثلاً: "كانت

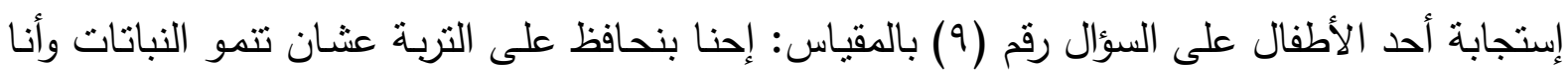

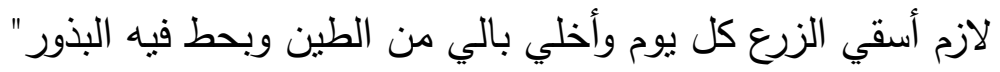
وتفسر الباحثة أسباب الإختلاف في إستجابات الأطفال إلى التالي:

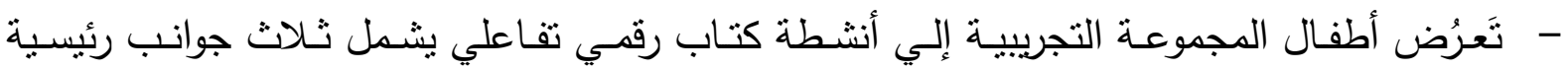

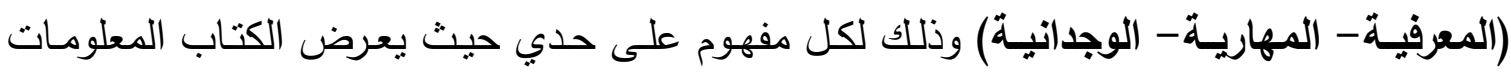
العلمية من مصادرها الرسمية، ثم يتتاول الطفل تلك المعلومات من خلال التطبيق عليها وبالتالي 
يكتسب مهارات علمية عن المفهوم، ثم يربط بين هذه المعلومات والمهارات بحياته اليومية وبالتالي أصبح هناك تكامل وشمول في تتمية الثقافة الجيولوجية للأطفال.

- - إعتمدت أنشطة الكتاب الرقمي التفاعلي على تنميـة المهارات التفكير العلمي المختلفـة لأطفال

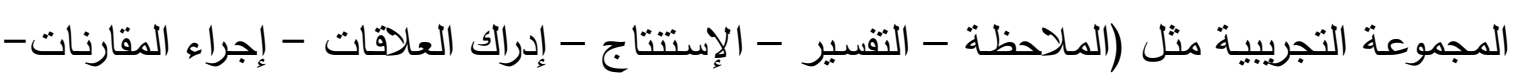

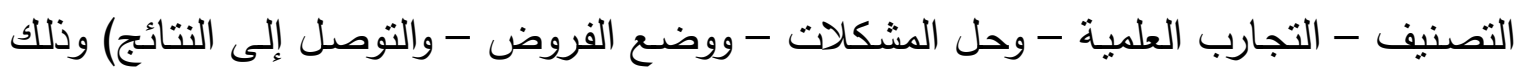
من خـلال الألعاب والتطبيقات المتتوعة الأساسية والمصـاحبة مدا أعطي الأطفال المتعـة والإثارة العقلية لإكتساب المفاهيم الجيولوجية. - - إكتساب أطفال المجموعة التجريبية مفاهيم تتسم بالحداثة والتي تتاولتها الثقافة الجيولوجية منل مفهوم الحفريات والرمل الأسود وهذا أعطي للكتاب الرقمي ثقل علمي وأعطي الأطفال المعلومات الجديدة

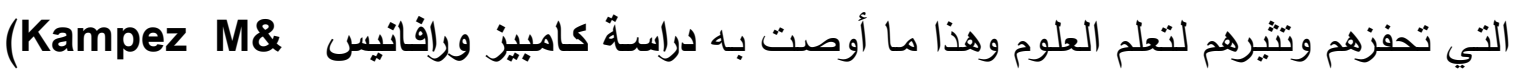

\section{.Ravanis, K,2013)}

- لم تكتفي الباحثة بعرض المفاهيم والمعلومات للثقافة الجيولوجية على الطفل رقمياً فقط بل قامت بإعداد أنشطة تتضمن المحتوى التعليمي للكتاب الرقمي مقسم إلى نشاطين لكل مفهوم، حيث يبدأ

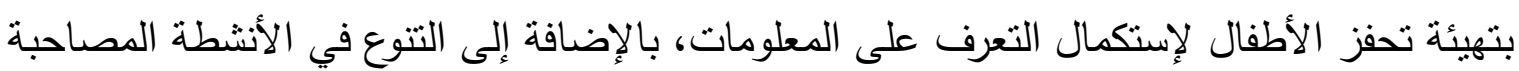

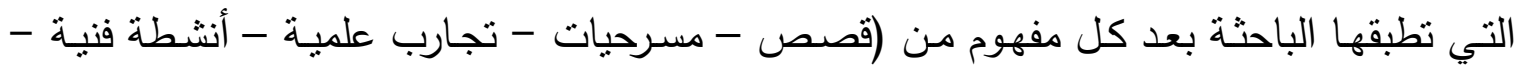

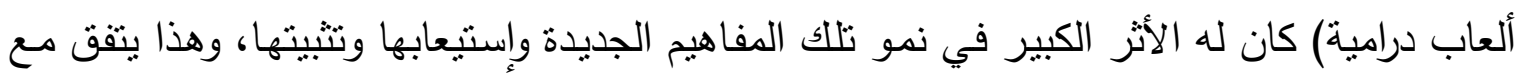

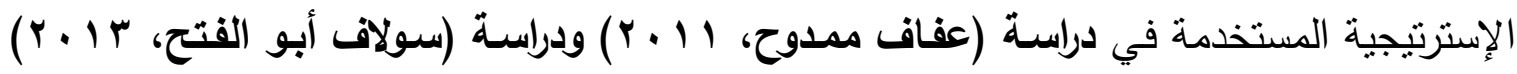
حيث إعتمدا على الأنشطة المصاحبة للمتاحف الجيولوجية لترسيخ المفاهيخ.

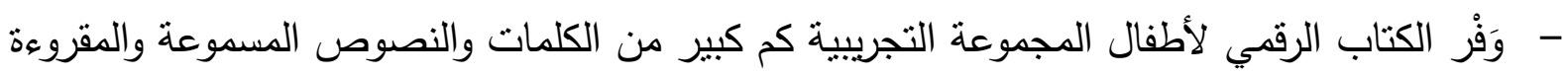

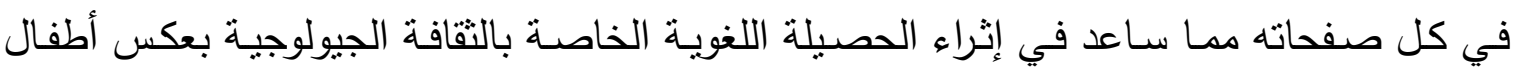

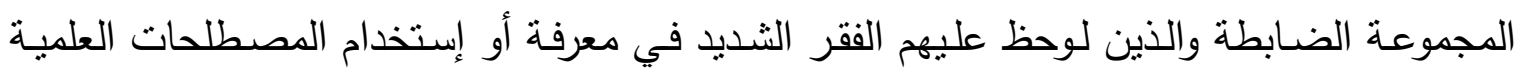
الجيولوجية لأنهم لم يتعرضوا للكتاب الرقمي.

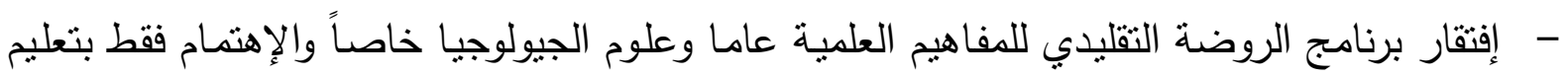

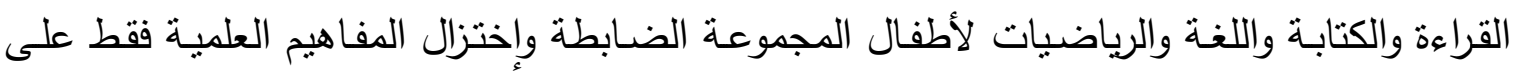

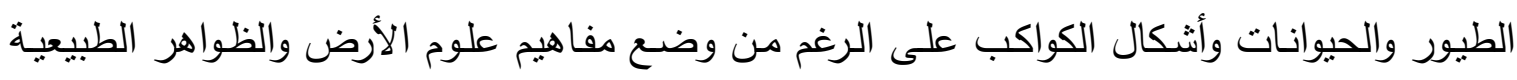

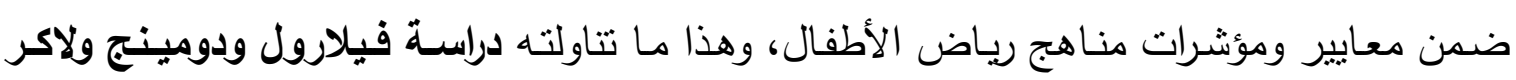
(Villarroel\&JosDoming\&Ros,Lker,2013) (Gulary\&Hulya, 2012)، حيث أكدا على أن هذه المفاهيم لها تأثير بالغ على تكوين شخصية 
- افتقار كتب ومجـالات رياض الأطفال من مفاهيم التقافة الجيولوجية وعلوم الأرض وهذا أدى إلى قصسور أطفال المجموعـة الضـابطة في إستيعاب هذه المفـاهيم على الرغم مـن تأكيد الكثير مـن الدراسـات على ضرورة تتمية مفاهيم مثل الموارد المائية والثورات المعدنية للأطفال كدراسـة أزسـوي

وبايبل (Ozsoy\& Sibel, 2013).

وتخلص الباحثة مما سبق إلى تحقق صحة الفرض الثاني بفروعه

خلاصة الاتنائج:

من خلال البحث الحالي تحققت جميع فروض البحث وكانت نتائجه كالتالي: ا ـ وجود فروق ذات دلالة إحصائية بين منوسطى رتب درجات أطفال المجموعة التجريبية قبل تطبيق أنشطة كتاب رقمي تفاعلي وبعد التطبيق على مقياس الثقافة الجيولوجية لأطفال الروضة لصالح

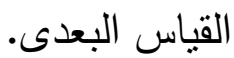
ץ. وجود فروق دالة إحصائيا بين متوسطي درجات أطفال المجموعة التجريبية وأطفال المجموعة الضابطة فى القياس البعدى، لتطبيق أنشطة كتاب رقمى تفاعلي على مقياس الثقافة الجيولوجية لأطفال الروضة لصالح المجموعة التجريبية. ويتفرع منه الفروض التالية: وجود فروق دالة إحصائية بين متوسطي درجات أطفال المجموعة التجريبية وأطفال المجموعة الضابطة فى القياس البعدى بالنسبة لبعد الأرض في تطبيق أنشطة كتاب رقمى تقاعلي على مقياس النقافة الجيولوجية لأطفال الروضة دونة لصالح المجموعة التجريبية. وجود فروق دالة إحصائية بين متوسطي درجات أطفال المجموعة التجريبية وأطفال المجموعة الضابطة فى القياس البعدى بالنسبة لبعد المخاطر المهددة للأرض في تطبيق أنشطة كتاب رقمى تفاعلي على مقياس الثقافة الجيولوجية لأطفال الروضة لصالح المجموعة التجريبية. وجود فروق دالة إحصائية بين متوسطي درجات أطفال المجموعة التجريبية وأطفال المجموعة الضابطة فى القياس لروفي البعدى بالنسبة لبعد الاستكشـافات الأرضية في تطبيق أنشطة كتاب رقمى تفاعلي على مقياس الثقافة الجيولوجية لأطفال الروضة لصالح المجموعة التجريبية. التوصبات والمقترحاث: فى ضوء نتائج البحث تُقدم الباحثة عدد من التوصيات والمقترحات على النحو التالي: ا ـ تفعيل معـايير ومؤشـرات مفـاهيم الثقافـة الجيولوجيـة وعلوم الأرض المتضـمنة ضـمن مـهـج ريـاض الأطفال بمصر لتحقيقها. r. الإهتمام بتتمية المجالات العلمية بفروعها من خلال توظيف برامج الحاسب الآلي في مرحلة رباض الأطفال والسنوات الأولي من المرحلة الإبتدائية. ب. عمل دورات تدريبية للطالبة المعلمة عن كيفية تقديم الثقافة العلمية عاما والجيولوجية خاصـا لأطفال الروضة من خلا الكتب والمجلات والحقائب الرقمية التفاعلية. 
ع. تفعيل دليل لمعلمات رياض الأطفال يشمل الخلفية النظرية والتطبيقية لجوانب العلوم وبخاصة العلوم الجيولوجية لكيفية تقديمها لأطفال الروضة.

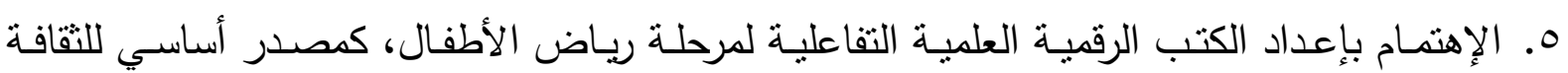
العلمية لأطفال الروضة يمكن اللجوء له في أب وقت.

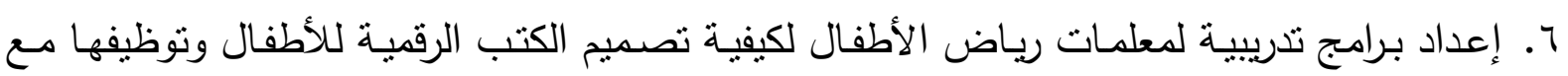
طفل الروضة لإكسابه العديد من الدفاهيم والثقافات العلمية المختلفة وغيرها. V. دراسة تتبعية عن فاعلية الكتاب الرقمي التفاعلي لتتمية الثقافة الجيولوجية لأطفال الروضة الرية.

\section{المراجع}

أولاً: المراجع العربية

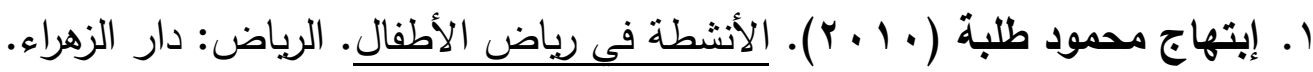

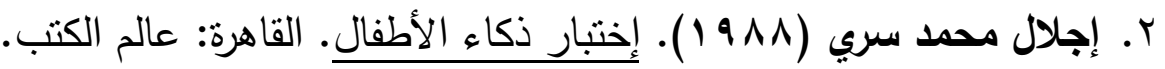

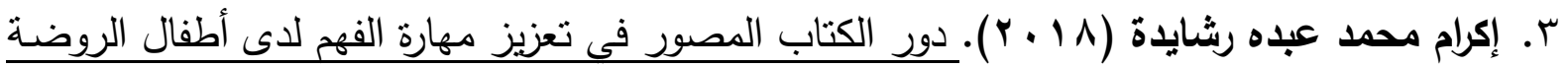

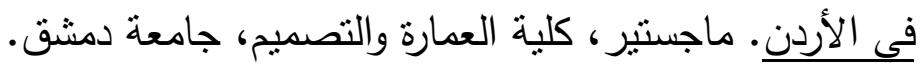

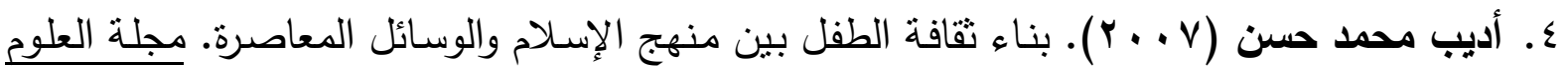
الإسلامية، العدد (ب0). ه. أحمد علي أحمد ابو زايدة (10 ب ب). الكتاب الإلكتروني المحوسب تعريفه وأنواعه ومميزاته. مصر :

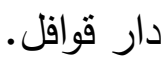

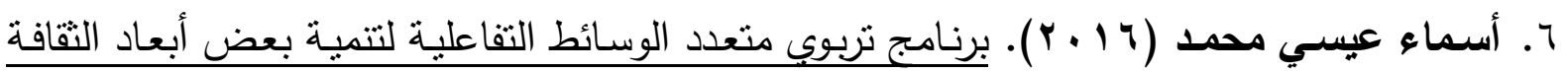

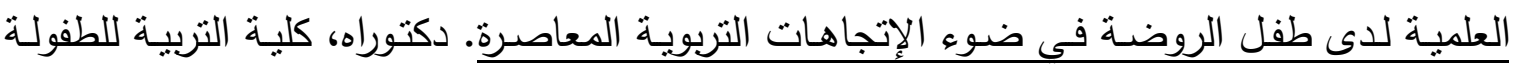

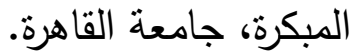

V. ألفت عبد الله إبراهيم العربي (Y V V V). فاعلية برنامج مقترح لإكساب طفل الروضة الثقافة العلمية

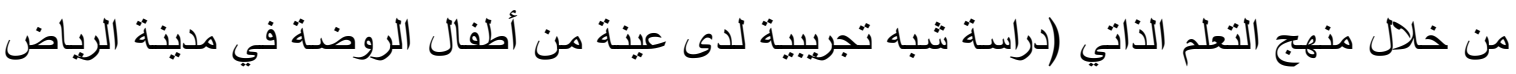

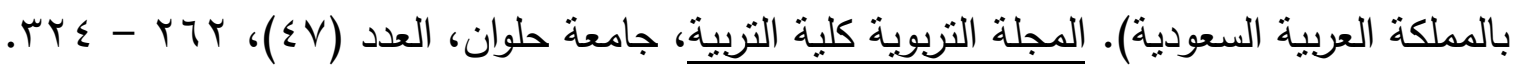

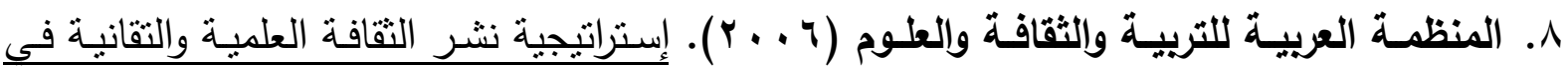
الوطن العربي. تونس: جامعة الدول العربية

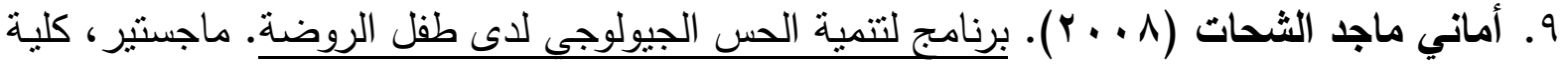

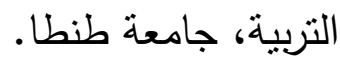




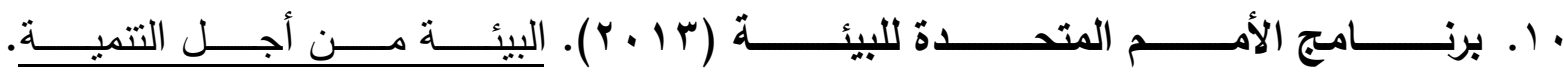
.http://www.un.org/Depts/Cartographic/english/9701474e.htm

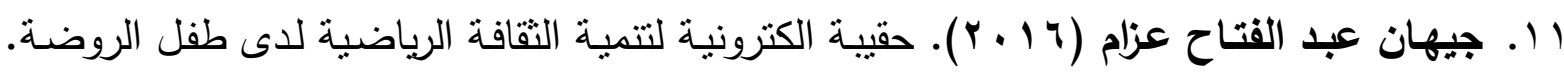
مجلة الطفولة، كلية التربية للطفولة المبكرة، جامعة القاهرة، العدد (Yr) (Y).

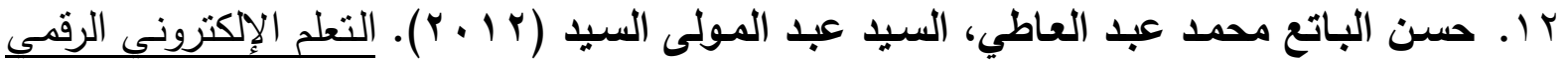
النظرية- التصميم- الإنتاج. الأسكندرية: دار الجامعة الجديدة.

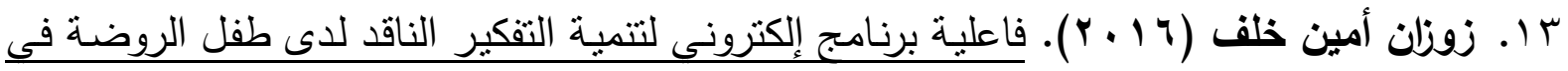
سوريا. دكتوراه، كلية الدراسات العليا للتربية، جامعة القاهرة.

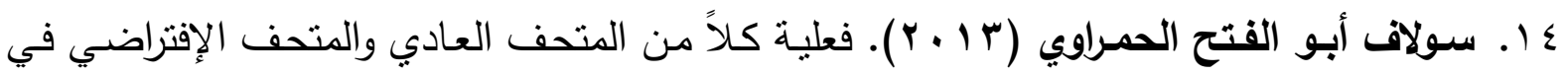

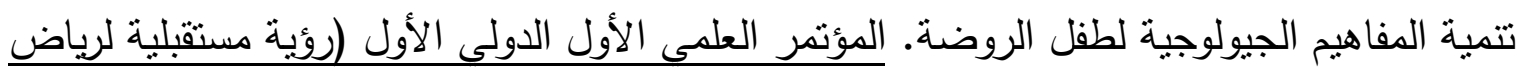

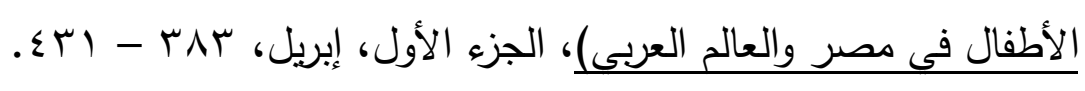

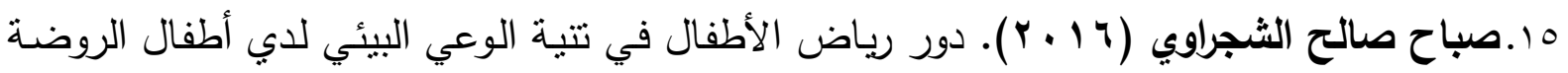

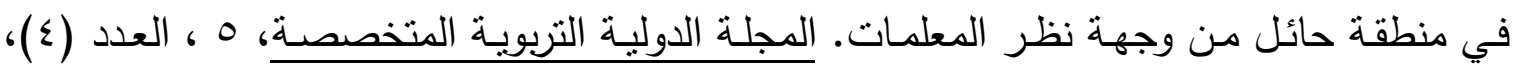
$.17 .-1 \leqslant 0$

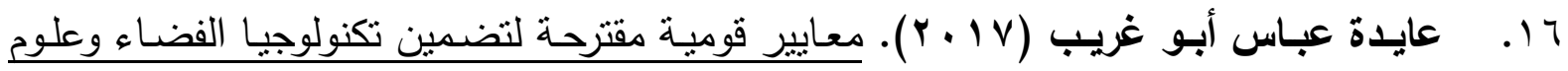

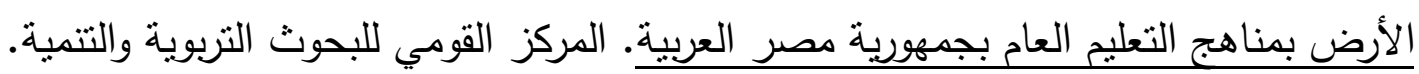

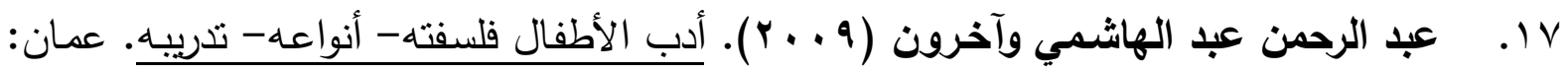
دار زهران للنشر.

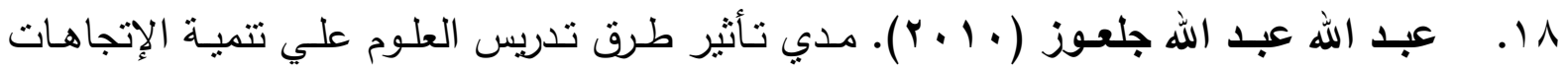

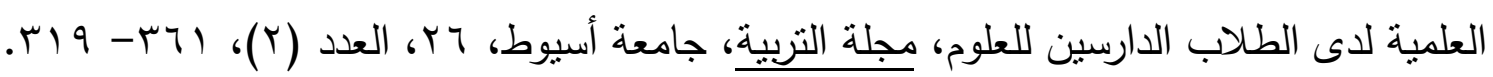

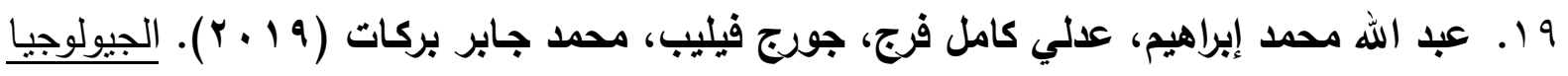

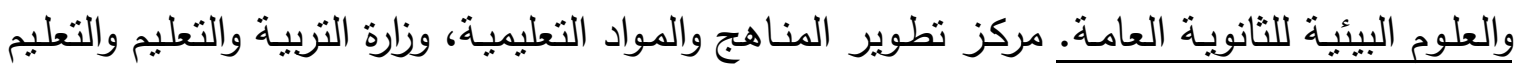
الفني، مصر.

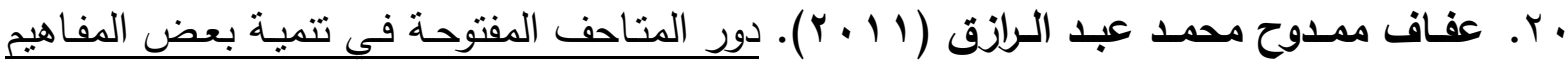
الجيولوجيا وادارة النشاط لدى معلمة الروضة في ضوء الخبرات الدولية. دكتوراه، كلية التربية للطفولة

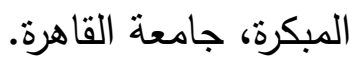

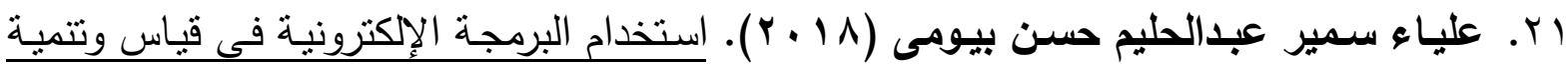
بعض العمليات المعرفية لاى الأطفال ذوى صعوبات التعلم. ماجستير ، كلية التزبية للطفولة المبكرة، 


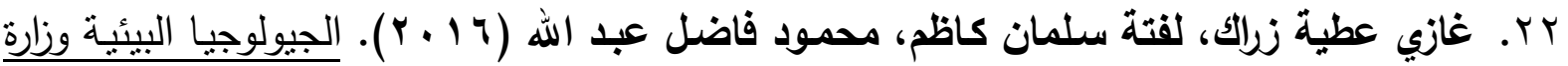

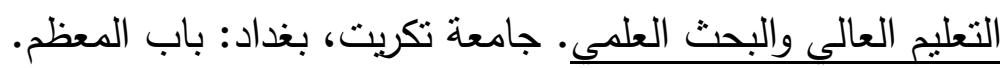

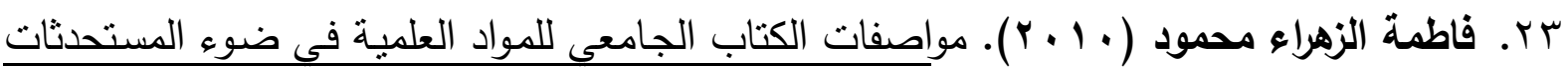
التكنولوجية المعاصرة. القاهرة: دار الكلمة.

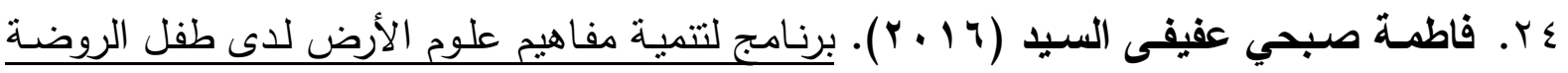

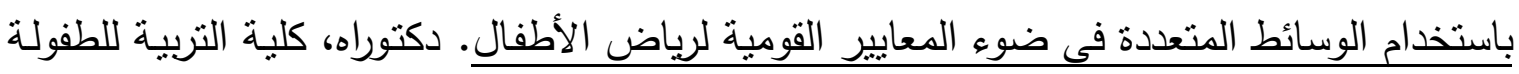
المبكرة، قسم العلوم التربوية، جامعة القاهرة.

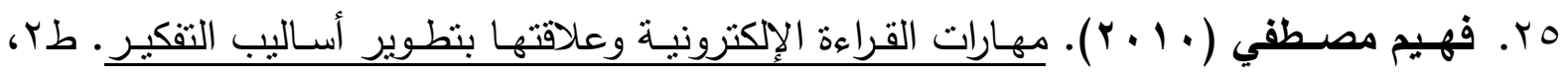
القاهرة: دار الفكر العربي.

جr. فيليب بوطز (9 9 ( ) ). الأدب الرقمي (ترجمة: محمد أسليم). الكويت: عالم المعرفة.

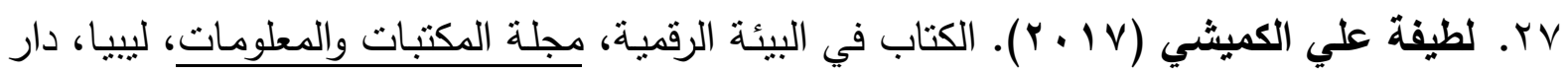

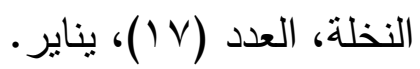

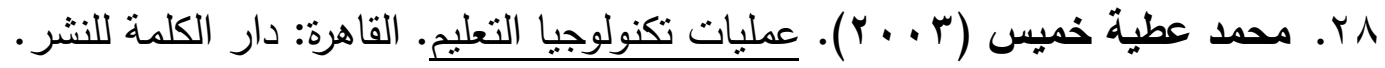
9.

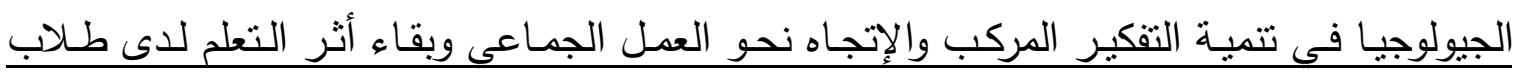
المرحلة الثانوية الأزهرية. دكتوراه، كلية التربية، جامعة أسيوط.

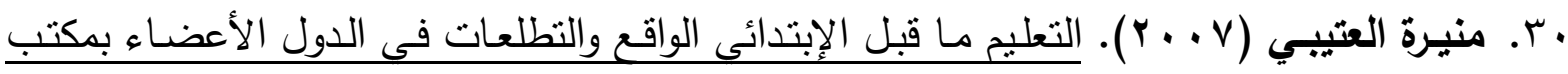

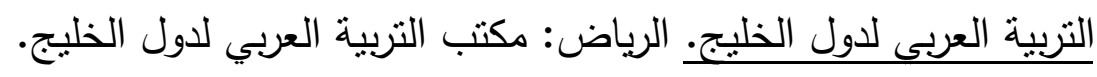

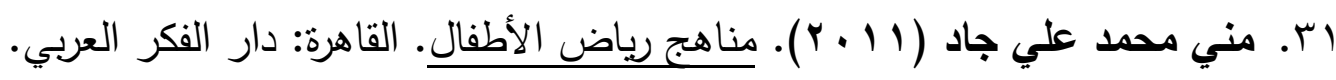

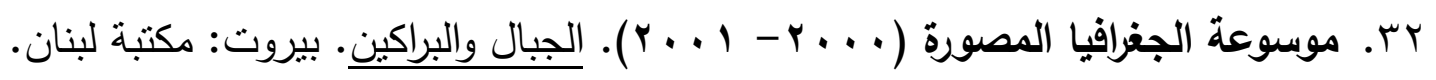

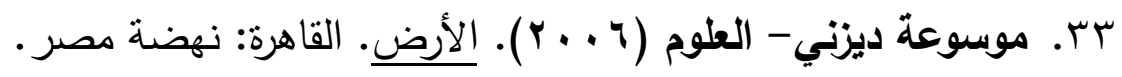

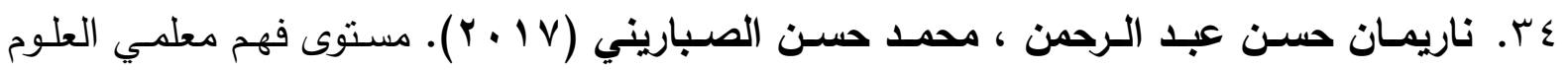

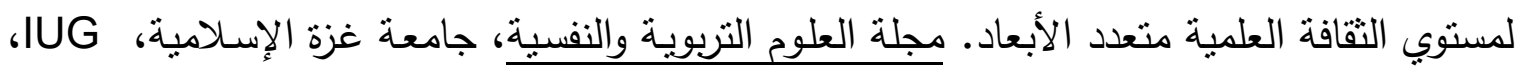
.Vol 25, No 4, pp. 504520

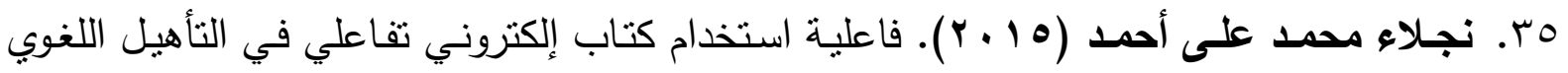

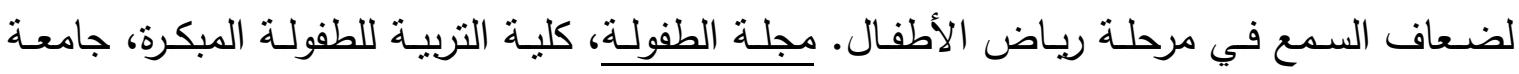

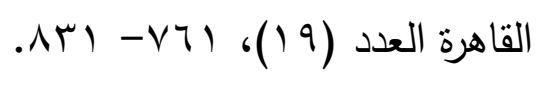

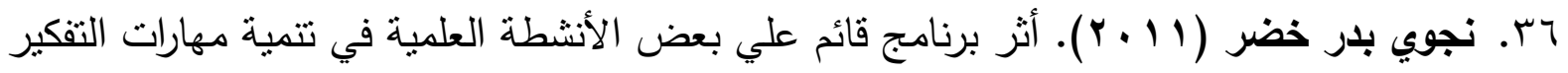

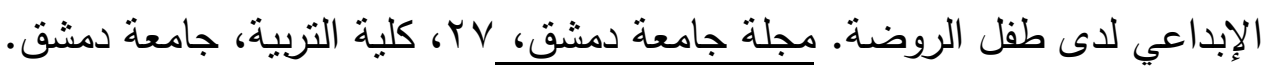




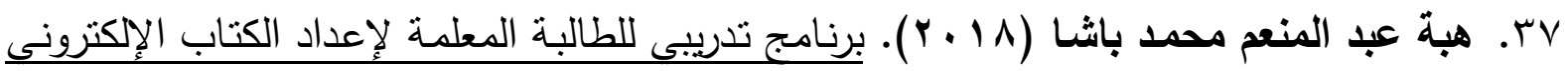

التفاعلى لتتمية بعض مجالات التعلم للأطفال المعاقين عقليا القابلين للتعلد. دكتوراه، كلية التربية

للطفولة المبكرة، جامعة القاهرة.

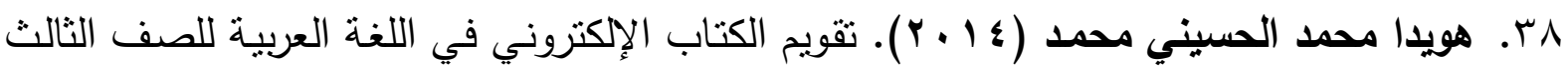

الإبتدائي في ضوء معايير الجودة. دراسـات عربية في التربية وعلم النفس، السعودية، يناير ، العدد

ثانياً: المراجع الأجنبية: Foreign References

39.Allan\& Mamoon (2014). Why do children visit Geological Tourism Site ?. Journal: Human and Social Sciences, Vol.41 Issue 1 Supl.1, pp.653-661.

40.Betty Sargeant (2015). What is an E-book? What is a Book App? And Why Should We Care? An Analysis of Contemporary Digital Picture Books. Volume 46, Issue 4, pp 454-466.

41.Charles R. Ault Jr. (2018). Time in Geological Explanations as Perceived by Elementary-School Students. Published online: 13 Feb 2018, 304-309.

42.Cinzia Cervato (2012). The Significance of Geologic Time: Cultural, Educational, and Economic Frameworks Iowa State University. an article from Geological Society of America Special Papers, cinzia@iastate.edu 486, 19, doi:10.1130/2012.2486(03).

43.Clement L. Chau (2014). Positive Technological Development for Young Children in the Context of Children's Mobile Apps. PhD, Tufts University. 44.Georgene L. Troseth\& Collen E. Russo\& Gabrielle A. STROUE (2016). What's next for research on young children's interactive media?. Journal of Children and Media, 10:1, 54-62, DOI: 10.1080/17482798.2015.1123166.

45.Giuseppe Di Capua (2009 - 2011). Istituto Nazionale di Geofisica e Vulcanologia. Rome: Italy.

46.Gloria Yi-Ming Kaoa\& Chin-Chung Tsai a\& Chia-Yu Liu b\& ChengHan Yang. (2016). the effects of high/low interactive electronic storybooks on elementary school students' reading motivation, story comprehension and chromatics concepts. Computers \& Education Journal, Elsevier Ltd. 
47.Gulay\& Hulya (2012). An Earthquake Education Program with Parent Participation for Preschool Children. Educational research and Review; 5(10), pp.624- 630, ISSN 1990-3839.

48.Heather Ruetschlin Schugar\& Carol A. Smith\& Jordan T. Schugar (2013). Teaching with Interactive Picture E-Books in grades $\mathrm{K}-6$. The Reading Teacher Vol. 66 Issue 8 pp. 615-624 DOI:10.1002/TRTR.1168 () 2013 International Reading Association.

49.Hendrik Knoche\& Anders Etzerdot\& Joacim ILykke\& Salling Pedersen (2014). Do interactions speak louder than words?: Dialogic Reading of an Interactive Tabletbased Ebook with Children between 16 Months and three years of age. at: https://www.researchgate.net/publication/266657647

50.Jeff Dodick (2003). Cognitive Factors Affecting Student Understanding of Geologic Time. OURNAL OF RESEARCH IN SCIENCE TEACHING, Department of Science Teaching, Weizmann Institute of Science, VOL. 40, NO. 4, PP. 415-442.

51.John Settlage \& Sherry A. (2012.) Teaching Science to Every Child Using culture as a starting point. Southerland, Routledge Taylor \& Francis , New York, London.

52.Johnson\& Charlotte (2012). Book Advantages Over Book. Me Kendree College's William Haroff, Available at; http://faculty.mckendree.edu/William_harroff/ebe/ebookadvatages_overpbook. htm.

53.Kampeza, M.\& Ravanis, K. (2013). An Approach the introduction of E lementary Earth Science Concepts in Earth Education of Kindergarten Using Multimedia Tools. Paper presented at the European Conference on Educational Research, University of Geneva, 13 - 15 September.

54.Kathleen Roskos\& Jeremy Brueck\& Lisa Lenhart (2017). An analysis of e-book learning platforms: Affordances, architecture, Functionality and analytics. International Journal of Child - Computer interaction, Elsevier ltd. 
55.Leah Zhang-Kennedy\& Yomna Abdel Aziz\& Sonia Chia-s son (2017).

Cyberheroes: The Design and Evaluation of an Interactive E-book to Educate Children about Online Privacy. International Journal of ChildComputer Interaction, School of Computer Science, Carleton University, Canada, DOI: 10.1016/j.ijcci.05.001.

56.Len Unsworth (2006). E- Literature for Children Enhancing digital literacy Learning. London: Routledge.

57.Mesut Saçkes (2015). Young Children's Ideas About Earth and Space Science Concepts. Research in Early Childhood Science Education, Balikesir University, DOL:10.1007/978-94-017-9505-0_319.04, pp.35-65).

58.Nadia Mena\& Ornalla Mich (2013). Interactive E-book for Children: what are they?, workshop at IDC interaction Design and Children. USA: New York city.

59.Ozsoy \& Sibel (2013). Is the Earth Flat or Round? Pre-school Children's Understandings of the Planet Earth: the Case of Turkish Children. International Electronic Journal of Elementary Education; 4(2): 407 - 415.

60.Roger Trend (2007). An investigation into understanding of geological time among 10- and 11-year-old children. 973-988 | Published online: 24 Feb 2007, https://doi.org/10.1080/0950069980200805.

61.Silvia Peppoloni\& Giuseppe Di Capua (2012). Geoethics and geological culture: awareness, responsibility and challenges. Vol 55, No 3 (2012).

62.Sommers, K. (2014). The Importance of Teaching Earth Science at Early Childhood. The Geological Society, America: USA.

63.Sutton, C.R. (2015). The learner's Prior Knowledge; A critical review of techniques for Probing its organization. European Journal of Science Education, 2, $107-220$.

64.Tim Martin (2019). Digital Books for Children. iPad illustrations Photo: Photolibrabry.com 
65.Villarroel\& Jos Domingo\& Ros, Lker (2013). A Program to Improve Young Children's Conception of Rain fall. A Study of Multimedia Use through Their Oral and Pictorial Explanation, International Education Studies; 6 (8), ISSN 1913- 9020.

66.Zahra Zerrouqi\& Abdelhafid Iyada\& Moussa Bouamiech (2016). Education on environment and its pollution using life and earth sciences textbooks in Moroccan middle schools. International Journal of Innovation and Applied Studies, ISSN 2028-9324 Vol. 17 No. 2 Jul. 2016, pp. 707-717. 